\title{
Adolpho Lutz em Manguinhos: casos sérios e divertidos
}

“Uma das
pessoas mais
importantes de
Manguinhos foi o
dr. Adolpho Lutz
... Ele sabia as
coisas bem
sabidas..."

“Uma das pessoas mais importantes de Manguinhos foi o dr. Adolpho Lutz ... Ele sabia as sabidas...”
Quando o Lutz veio para cá ele já tinha feito tanta coisa! Era maior do que qualquer um aqui. Tinha sido convidado para dirigir, no Havaí, aquele célebre leprosário de Molokai, onde frei Damião apanhou lepra. Lutz tinha trabalhado com o Unna, que era um dos grandes microbiologistas da época. Lutz fez lá uma descrição do bacilo da lepra mostrando o que nunca ninguém tinha visto. Ele disse: "Esse bacilo tem uma estrutura." O pessoal descrevia o bacilo como uma linha; ele viu que dentro daquela linha tinha carocinhos e viu isso corando, mas principalmente a olho, no microscópio, sem coloração. Lutz descreveu o bacilo de Hansen e dizia: "Isso não é micobactéria porque para ser 'mico' tem que ser semelhante ao cogumelo, e isso aí é uma seqüência de granulações." Deu o nome de Coccothrix a esse micróbio, porque eram cocos, carocinhos; thrix é um rosário de cocos. Lutz ficava uma fera quando alguém falava em micobactéria perto dele: "Precisamente, isso não é nem mico nem bactéria, é outra coisa." Uma vez saiu uma discussão aí no Centro de Estudo. O Perissé apresentou um trabalho sobre lepra e vieram leprólogos, inclusive um sujeito que diziam que era o maior conhecedor de micobactérias lá do Fundão. Então o Luís Fernando perguntou para a dra. Lígia Madeira, que é lepróloga: "Por que é que o negócio do Coccothrix do Lutz não pegou?" Ela disse: "Não sei." O dr. fulano, lá do Fundão, também não sabia. "Será que alguém sabe?" E eu, sem jeito, explico: o Coccothrix do Lutz não é aceito - nomen nudum, como dizem os zoólogos porque não vem revestido da pompa necessária. Antigamente, no mundo vegetal, a primeira descrição tinha de ser em latim e, depois, se quisesse, em outra língua. Isso também valia para parasitos animais. Hoje, para planta, ainda precisa ser assim; para parasitos, para animais, em geral, não precisa mais. Hoje é facultativo, mas tem que ser em francês, inglês ou alemão. Lutz perdeu por uma questão formal. Não descreveu em latim e o pessoal ficou usando sempre micobactéria, e não tem mais graça mudar um negócio que está consagrado.

(Entrevista de Wladimir Lobato Paraense, maço 17, pastas VII-XX)

Uma das pessoas mais importantes de Manguinhos foi o dr. Adolpho Lutz. Ele fez tese na Suíça, falava todas as línguas, falava ou entendia até aquele dialeto havaiano, pois esteve no Havaí. Era incrível o Lutz. No dizer do Costa Lima, foi o único sábio que conheceu. Ele sabia as coisas bem sabidas, de patologia, medicina, entomologia médica, microbiologia, todas as coisas. Nunca esqueço do dia em que estávamos numa sessão da Sociedade Brasileira de 
Biologia, ${ }^{3}$ então o dr. Lacorte apresentou um trabalho sobre a micobactéria da tuberculose. Para surpresa nossa, o dr. Lutz levantouse e foi no quarto dele - era o único que tinha um quarto só dele no quarto andar - , foi lá, pegou uma separata, entrou pela porta e disse: "Precisamente, dr. Lacorte, isso eu já fiz há trinta anos!" E jogou em cima da mesa aquele trabalho.

Ele tinha caixas, coleções enormes de muitos bichos interessantes que ainda estão na Coleção de Manguinhos, e lá estavam os pantoftalmídeos, que parecem uma mutuca, uns bichos enormes que são broca de madeira. Um dia eu disse: "Dr. Lutz, estou interessado em estudar os pantoftalmídeos." Ele viu meu interesse, viu que eu estava estudando mesmo os bichos e me tratava com uma deferência muito especial. O Joaquim Venâncio, auxiliar do Lutz, foi um dos maiores amigos que já tive. Um dia, quando eu ia para Goiás, fui perguntar ao dr. Lutz se queria alguma coisa. E ele me pediu para trazer aquilo. Sempre tinha interesse em tudo, não é? Então, na hora da saída disseme o Joaquim Venâncio: "Está vendo o interesse do velho? Chegou até a lhe oferecer cigarro!" Achei graça, porque o dr. Lutz era considerado unha-de-fome, mas não era não. Era uma pessoa muito boa, um distraído, que nunca oferecia cigarro a ninguém.

(Hugo de Souza Lopes, p.14, fita 1, lado B, 1르 entrevista)

“O Lutz não formava ninguém. Era um solitário...”
O Lutz não formava ninguém. Era um solitário e eu entendia muito bem. Também sou um bocado assim. Não tenho paciência. O sujeito chega, não sabe nada, eu tenho que parar tudo para ensinar o bê-á-bá. Agora, quando vem um sujeito que tem talento e disposição... Formei uns quatro que estão aí, mandando brasa. Então o Lutz era mais solitário, e trabalhava com o Neiva, que era do nível dele; quer dizer, não por causa da idade, o outro tinha mais experiência, mas era um sujeito que podia discutir se Chrysops era masculino ou feminino, e o Lutz o levava a sério.

(Entrevista de Wladimir Lobato Paraense, maço 20, pastas VII-XX)

Eles tiveram uma discussão brava aqui. Quando estavam trabalhando juntos, escrevia um ou senão o outro. O Lutz escrevia em alemão e o Neiva passava para o português. Botava 'a Chrysops'. O Lutz via na prova e deixava passar, mas um dia chegou e disse: "Não, Chrysops é masculino." E o Neiva: "Não, é feminino." E saiu um pega, o Neiva com muito respeito, porque respeitava o Lutz. Outros diziam: "Não doutor, olha aqui...", e mostravam, "mas, precisamente, é masculino", redargüia ele. Aí, no fim, para calar a boca do Lutz, como quem diz:

\footnotetext{
${ }^{3}$ As sessões regulares da Sociedade Brasileira de Biologia eram realizadas na biblioteca de Manguinhos.
} 
"puxa, um homem desses cometer um erro?", Neiva foi lá dentro, pegou um dicionário de grego e mostrou-lhe: "Olha aqui, está vendo? Feminino!" O Lutz olhou, olhou e não disse mais nada. Ficou fazendo assim, como quem está rezando. No outro dia de manhã, foi à biblioteca e disse: "Mande chamar o dr. Neiva." Chegou o Neiva. "Veja aqui." Trouxera Homero em grego: "Veja aqui se Chrysops é masculino ou feminino." O Neiva não sabia grego. Olhou, olhou... "Como? Mas o dicionário escreve..." "Precisamente, aquele dicionário está errado." Os dois tinham razão, pois a regência depende do contexto, mas Lutz sabia porque achou em Homero. Ficou fazendo assim, recitando algum trecho que conhecia. Fazia isso muito. Às vezes quando fazia captura, ou quando estava cansado, começava a recitar Homero.

(Entrevista de Wladimir Lobato Paraense, maço 17, pastas VII-XX)

Nas excursões a pé, quando cansado, costumava sentar-se embaixo de uma árvore e declamava Homero no original. Era repousante. Para ele.

(Luiz Fernando Ferreira da Silva, 1992, pp. 157-71)

A entomologia aqui foi realizada primeiro pelo Lutz, que tinha montões de trabalhos, mas ele era um compartimento à parte, ninguém o incomodava. Trabalhava muito, não tinha outra atividade que não fosse pesquisa. Havia no Instituto verdadeiros tabus: "Ah, isso vai incomodar o Lutz." O negócio era assim. O que dr. Lutz quisesse fazer, podia. Se quisesse ficar de cabeça para baixo, e de perna para o ar o dia todo, ninguém ia perguntar por que estava assim. Era sagrado isso.

Então, o Lutz e a entomologia dele eram coisa à parte. É verdade que ele tinha trabalhos com o Costa Lima. Admiravam-se muito. E com o Neiva, também. Tinha o laboratório do Costa Lima, que também era um mistério. Vivia determinando pragas, estudando bichos de interesse médico. O César Pinto também teve muita importância. Trabalhava no laboratório do canto, naquele primeiro andar. Lembram-se onde era o laboratório do dr. Lutz, onde hoje fica o museu? Depois tinha aquele outro laboratório, que era a sala das coleções, e logo vinha o do César Pinto, depois os dois do Costa Lima. A entomologia do Travassos já era diferente. Ele tinha um laboratório de helmintologia. Um dia resolveu estudar borboletas. Coincidiu com a fase em que veio para cá. Esse assunto tinha sido escolhido por ele, em São Paulo, para o Severino Vaz, que entrou na helmintologia. O Travassos veio para o Rio com aquela preocupação de estudar os sarcofagídeos, um bicho que ia dar muito trabalho, porque nunca fora estudado. O Herman Lent estudava helmintologia, fez uma porção de trabalhos com o Teixeira de Freitas. De repente, começou a estudar barbeiros, e hoje é o melhor especialista que já apareceu sobre o assunto.

(Hugo de Souza Lopes, p. 34, fita 3, lado A, 2entrevista) 
Lutz era, realmente, uma figura singular. Sua miopia fazia com que estivesse sempre com o queixo levantado, o que habitualmente dá às pessoas uma impressão de altivez. Mas Lutz era um homem tão simples, tão chão, que ninguém ia pensar que aquilo fosse ato de soberba.

(Carlos Chagas Filho, 18.2.1987 a 2.9.1987, p. 16, fita 5, lado B; p. 1; fita 6, lado A, 3 entrevista)

Um fato curioso que se contava dele é que se vestia de acordo com o termômetro. Tendo quebrado o termômetro, apareceu várias vezes no Instituto com roupas muito quentes, no verão.

(Carlos Chagas Filho, 18.2.1987 a 2.9.1987, p. 16, fita 5, lado B)

"Sua miopia fazia

com que estivesse sempre com o

queixo levantado, o que

habitualmente dá

às pessoas uma

impressão de

altivez."
Tinha um termômetro na entrada (do Castelo mourisco), quando se desce a escada. O dr. Lutz, todos os dias, na hora do almoço, olhava a temperatura. Então, pegaram uma pedrinha de gelo, encostaram na cúpula do termômetro e ficaram esperando ele aparecer lá em cima da escada. Aí, todos se esconderam depressa. O Lutz olhou assim, virouse para o pessoal, deu um muxoxo e foi sentar.

(Hugo de Souza Lopes, p. 34, fita 3, lado A, 2a entrevista)

Durante anos, meu pai trouxe almoço para o Lutz. Porque ele se queixava muito do almoço de Manguinhos. Então meu pai convenceu minha mãe a fazer uma marmita para o Lutz. Na verdade, nunca vi o Lutz no caramanchão. Comia sempre em seu laboratório, que se caracterizava por uma grande ordem. Se era dada pelo próprio Lutz ou pelo Joaquim Venâncio, não sei. Acho que não queria perder tempo. A única vez que o vi perto do caramanchão foi naquela famosa fotografia em que estão os médicos alemães Duerck e Prowazek, Hartmann, meu pai e os outros membros do Instituto, ao lado do Lutz. Todos, aliás, com chapéus muito elegantes, chapéus-do-chile. É verdade que comecei a almoçar no caramanchão muito mais tarde, depois de 1930.

(Carlos Chagas Filho, 18.2.1987 a 2.9.1987, p. 16, fita 5, lado B)

Eram pesquisadores do maior gabarito, sabe? Chegavam a fazer refeição na mesa deles de trabalho. Naquele tempo, a dedicação era fora do comum. Assisti muitas vezes o dr. Lutz comendo sanduíche e a mão no microscópio; dava mordida no sanduíche, ficava mastigando e olhando no microscópio. Eram homens que se dedicavam de corpo e alma, passavam às vezes uma semana fora de casa, dormindo aqui para continuar uma pesquisa que não pudesse ser interrompida. A gente se sentia também entusiasmado para ver o resultado final. A gente sentia aquele entusiasmo e procurava auxiliar em tudo.

(Francisco Gomes, 9.1.1986, fita 4, lado A, 2르 entrevista) 
Com a dificuldade de trânsito, naquela época, meu pai costumava buscá-lo freqüentemente, creio mesmo que diariamente, na rua do Matoso. Morava numa casa muito simpática, defronte a qual, mais tarde, fez-se um dos grandes palacetes do Rio de Janeiro, do dono da refinaria de Manguinhos. Era uma casa muito simpática, muito simples. Nunca entrei porque ficava no automóvel, esperando.

(Carlos Chagas Filho, 18.2.1987 a 2.9.1987, p. 16, fita 5, lado B; p. 1, fita 6, lado A, 3르 entrevista)

Certa vez, o diretor do Instituto, acompanhando ilustre figura da política nacional, um senador, entra no laboratório do dr. Lutz, que está ao microscópio. Com certa timidez, pede que mostre o laboratório ao visitante. Lutz, sem levantar o olho do microscópio responde: "Precisamente, o Venâncio vai mostrar, porque estou muito ocupado."

Certa vez, em viagem pelo interior, a pé, fazem pausa para descansar. Lutz abre um pacote com bananas e começar a comer. Famintos, os outros olham com avidez. "Ah! Os senhores gostam de bananas?" "Sim, dr. Lutz, gostamos muito." "Da próxima vez, façam como eu, tragam bananas."

Contra os especialistas, afirmava: "São uns seres felizes, presumem saber ilimitadamente todo o setor científico em que trabalham e se arrogam o direito de poder ignorar tudo o mais."

Certa vez, em viagem de estudos pelo interior, chegam a uma pequena vila. São recebidos com entusiasmo. Médicos de Manguinhos. Ainda bem. Um caso de parto complicado. A parteira não consegue resolver. Os jovens cientistas que o acompanham se entreolham, literalmente apavorados. Tranqüilo, Lutz entra na casa. Examina a mulher e faz o diagnóstico: apresentação podal. Executa as manobras necessárias. A criança nasce. Do lado de fora sentencia: "Precisamente, todo médico tem que ser capaz de resolver situações como essa."

"Precisamente, os homens é que deviam montar de lado, porque as mulheres não têm certos órgãos que ficam amassados contra a sela."

Foi quando o rei Alberto veio ao Brasil, em 1922. Criou-se a Universidade do Rio de Janeiro, para dar um título honorífico ao ilustre visitante. E como ele tivesse que transitar pela rua do Catete, criou-se a zona do Mangue, tirando os prostíbulos do ilustre trajeto. A rainha era naturalista amadora. Fez-se então uma comitiva para acompanhá-la em passeio a cavalo, pelas florestas dos arredores. Lutz, muito contrafeito, foi incluído no grupo. E como não podia deixar de ser, o Venâncio foi junto. Nesse tempo, as mulheres montavam de lado na sela. ... uma das damas da rainha, querendo mostrar-se gentil, aproxima seu cavalo ao do sábio caturra e procura puxar conversa. Sem ouvir o que lhe foi perguntado, Lutz pontifica, dirigindo-se à jovem: "Precisamente, os homens é que deviam montar de lado, porque as mulheres não têm certos órgãos que ficam amassados contra a sela."

(Luiz Fernando Ferreira da Silva, 1992, pp. 157-71) 
“Uma

recordação que

eu tenho é ... o

Lutz já cego,

sentado no

penúltimo degrau

da escada, a

Bertha Lutz ao

lado ... lendo

para ele."
O dr. Lutz viu que estava ficando sem vista com a idade. Ficou praticamente cego, e então passou dos mosquitos, dos insetos, para os anfíbios. Porque - isso eu assisti - ele segurava um anfíbio já fixado, segurava as patas e via se tinha ampolas nas unhas, ou se tinha crista ou glândulas parótidas, e perguntava para o Joaquim Venâncio: "De que cor é esse bicho, Joaquim?" E determinava os bichos assim, por palpação.

(Hugo de Souza Lopes, p. 14, fita 1, lado B, 1aㅡ entrevista)

Uma recordação que eu tenho é chegar no Instituto e encontrar o Lutz já cego, sentado no penúltimo degrau da escada, a Bertha Lutz ao lado, sentada também na escada, lendo para ele. Todo dia faziam isso.

(Sebastião José de Oliveira, 1.9.1986 e 25.2.1986, p. 9, fita 6, lado A).

Evandro Chagas, moço ainda, foi um expoente da ciência. Era de uma versatilidade muito grande, como Adolpho Lutz, que era superversátil. Esse, então, sabia de tudo: era clínico, microbiologista, bioquímico, tudo. Lutz era o campeão. Uma coisa muito engraçada aconteceu numa reunião em que propuseram: "Vamos acabar com a esquistossomose no Nordeste. Como o pato come o caramujo, o negócio é, nos lugares endêmicos, dar um casal de patos a cada nordestino." Então ele levantou e disse: "Mas é preciso primeiro alimentar os nordestinos, porque senão a primeira coisa que vão fazer é comer o casal de patos." Era formidável, o Adolpho Lutz. Foi quem avisou o governo sobre a entrada da malária aqui. Aqueles hidroaviões vinham do continente africano para Natal, e ele preveniu que deveriam ficar mais ou menos a $1 \mathrm{~km}$ de distância do continente e serem expurgados antes de pousar no território brasileiro. Que no bojo deles poderia vir o mosquito transmissor da malária. ${ }^{4}$ Mas não tomaram essa providência, e quando a malária apareceu aqui, e veio pelo Nordeste afora, foi uma calamidade muito grande.

(Francisco Gomes, 9.1.1986, fita 4, lado A, 2 ${ }^{\underline{a}}$ entrevista)

Já lhe contei a história do dr. Lutz com o professor Ernest Marcus? Era um alemão muito importante que veio ensinar zoologia em São Paulo. E, como todo alemão que se prezava, a primeira coisa que fez foi visitar o dr. Lutz, que era famoso. Ele, então, brincava com esses camaradas por causa da ignorância que tinham das coisas do Brasil.

\footnotetext{
${ }^{4} \mathrm{O}$ entrevistado refere-se ao Anopheles gambiae, transmissor de uma forma grave de malária importado da África ocidental, localizado no Brasil em 1930 e erradicado em 1940 pelo Serviço de Malária do Nordeste.
} 
Quando chegou o Marcus, pegou um pedaço de pita e perguntou: "Você já viu essa madeira?" O Marcus segurou aquilo, era leve. Depois pegou um pedaço de pau-ferro, um troço pesado, deu para o camarada. Ele ficou com medo. Depois pegou uma lombriga que estava dentro de um vidro grande, e perguntou: "Você já viu isso?" O Marcus disse: "Deve ser um animal marinho, não é, dr. Lutz?" E o dr. Lutz falou: "Precisamente, pois se está no rim de tudo quanto é cachorro." O que ele queria dizer é que o sujeito que vem de fora, muito sabido, vem ensinar o que num ambiente que não conhece? Então, o professor Marcus disse para ele: "Mas o senhor está me passando uma sabatina, hein, dr. Lutz?" E este respondeu: "Precisamente, e você está perigando, está perigando."

(Hugo de Souza Lopes, p. 30, fita 4, lado A) 


\section{Sobre Joaquim Venâncio}

Filho de José Venâncio Fernandes e Maria de Jesus, Venâncio Bonfim nasceu no município de Juiz de Fora (MG), em 8.11.1916, na Fazenda Bela Vista, que pertencia à mãe de Carlos Chagas. Em 1935, mudou-se para o Rio de Janeiro e logo conseguiu dinheiro para trazer a família toda. Quando chegou à capital, hospedou-se na casa do tio, Joaquim Venâncio, na fazenda de Manguinhos.

"Joaquim Venâncio foi criado sem pai nem mãe, junto com o dr. Carlos Chagas, o diretor do Instituto Oswaldo Cruz, e meu pai também. Foi o primeiro a abandonar a fazenda e vir para a cidade. $\mathrm{O}$ dr. Chagas arrumou serviço para ele aqui. Morava nas circunvizinhanças da Fundação. Se os senhores forem ali pela rua onde é hoje o laboratório de vírus, nos fundos, o Venâncio morava ali. Não havia nada daquilo. Era mato. Aquela casa foi o Instituto que fez para ele.

Trabalhava com o dr. Adolpho Lutz, que em quase todas as viagens quis levar o Venâncio. Inclusive aos Estados Unidos. O dr. Lutz fez questão que o Venâncio seguisse com ele. Pressionaram o diretor tendo em vista aquele problema do racismo nos Estados Unidos. Ele foi ao dr. Lutz, disse: "Não poderia levar outra pessoa?" O Lutz ficou quieto, que era de pouca palavra. Ficou quieto, foi ao diretor - ele tinha um sistema de falar assim: dizia sempre "precisamente" — : "Senhor diretor, precisamente, meu auxiliar chama-se Joaquim Venâncio Fernandes. Ou ele ou ninguém." Aí o Venâncio foi. Acompanhou o Lutz até a morte.

Bom, eu cheguei sem aviso. Vim, assim, no "sputnik", analfabeto de pai e mãe, meio envergonhado. Gostaria que não fosse preciso eu voltar. O Venâncio supervisionava as áreas do Instituto à noite também. Porque isso aqui era um aberto. Lá para o lado da patologia, tinha uma estrada que cortava tudo isso. E havia invasão aqui. Quando eu cheguei à casa do Venâncio, à noite, ele estava supervisionando. No outro dia, falei para ele: "Olha, meu tio, vou fazer para o senhor um galinheiro." Construí o galinheiro e comecei a tomar conta dos bois dele. Ali, como quem vai para a refinaria de petróleo, tem lá uma pilastra meio caída, ali dava passagem. O gado ia lá para um lugar de nome Benfica. Pelos fundos, nessa estrada de rodagem, não podia deixar. Tinha um problema que chamava curral de conselho, que era uma seção da prefeitura que capturava todo animal abandonado. Eu tinha que estar sempre vendo, sempre ativo. Tinha aproximadamente umas 15 cabeças, vaca leiteira e tudo. Era dele. Porque isso aqui era uma fazenda.

$O$ Venâncio supervisionava à noite. Também se botava um vigia, com um rifle nas costas. Havia as pessoas de cocheira, que tomavam conta dos animais, então faziam mais uma companhia. Eram duas cocheiras, ou três. Como a produção de soro aqui era muito intensa, tínhamos muitos cavalos. 
Fiquei com Joaquim Venâncio talvez um ano, ano e pouco. Foi passando, passando, quando o Capanema me contratou como trabalhador de $4^{a}$ classe. E quando se deu uma vaga de uma senhora que trabalhava na lavanderia, d. Cipriana, daí eu fui servente $5^{\underline{a}}$ classe.

(Entrevista de Venâncio Bonfim, 11.11.1986, fita 1, lado A, 1르 entrevista).

Joaquim Venâncio era meu guru. Muita coisa que aprendi, agradeço a Joaquim Venâncio. Era de uma inteligência fora do comum. Essa reação para o diagnóstico da gravidez que se fazia em bufo marinho, foi o Joaquim que descobriu. Ele trabalhava com o dr. Lutz e o Joaquim, muito sagaz, fazia exames de urina. Um dia, pegou urina de uma senhora aí do morro que estava em período de gravidez. Enquanto o Joaquim estava no microscópio examinando o sedimento da urina dela, ela, como tinha aversão a sapo, pegou um daqueles vidros e jogou em cima do bufo marinho, sabe? E o Joaquim estava colhendo uns protozoariozinhos. $\mathrm{O}$ dr. Lutz tinha mandado ele fazer sondagem na cloaca para identificar se o bufo marinho tinha esse tipo de protozoário. Quando chegou no dia seguinte, fez a punção na cloaca do sapo, colheu a urina e foi para o microscópio, viu aquele montão de espermatozóide. "Uai!" Ficou intrigado com a coisa. Aí notou que embaixo (porque o sapo não ficava no chão do vidro, ficava sobre uma placazinha), embaixo tinha urina. Deu um estalo na cabeça dele. Mandou que a moça trouxesse nova urina. A moça trouxe, e ele, mais do que depressa, injetou $10 \mathrm{~cm}$ daquilo no sapo. Primeiro, sondou a cloaca, viu que não tinha nada; fez a injeção de urina, uma hora depois, colheu o material, com duas horas, colheu, já estava lá a espermatorréia no sapo. Aí contou ao dr. Lutz o que tinha descoberto, e disse que tinha explicado aquilo ao dr. Manini. Foi quando o dr. Lutz ficou desesperado: "Não conta nada à gente de fora. Você contou, agora ele vai publicar isso." Então, o dr. Lutz desenvolveu a coisa toda, deu a noção científica do que era aquilo: era a gonadotrofina coriônica que liberava o espermatozóide no sapo.

Houve uma coisa muito curiosa com o Joaquim. Ele era demais inteligente. Um embaixador alemão mandou uma carta para o diretor: se o Instituto poderia enviar para a Alemanha 12 exemplares de um tipo de uma perereca estranha que tinha no Brasil, muito rara. Então o diretor chamou o Joaquim, se ele podia satisfazer esse pedido: "Ah, pois não", e saiu em campo. Vestiu as botas e aquele traje de pântano, e conseguiu exatamente o tipo. Mandou tudo determinado: espécie, tipo, hábitat, escreveu tudo, e eu é que fui levar lá na Embaixada da Alemanha, nas Laranjeiras. O embaixador ficou maravilhado. O Joaquim conseguiu aquilo de um dia para o outro.

Pelo coaxado do bicho, sabia onde estava e que tipo de bicho era. Ia lá direitinho. O dr. Lutz tinha uma certa afeição ao Joaquim, que era realmente inteligente, ajudava mesmo o dr. Lutz, em tudo. O dr. Lutz 
“O dr. Lutz era versátil, clínico, cientista, era tudo." era versátil, clínico, cientista, era tudo. Eu estive também algum tempo trabalhando com ele. Era formidável. Um pouco difícil de a gente entender, porque o português dele ainda era assim meio arranhado, né? Então era preciso a gente botar bem atenção, porque senão a gente não sabia bem o que ele estava querendo. Mas com o hábito, acostumava.

Um dia, eu estava com Thales Martins - quando Miguel Osório viajava, eu ficava com o Thales Martins - super, ultra-exigente. Queria uma coisa já, não queria saber de que forma a gente ia conseguir. Fui eu que mais agüentei o Thales Martins, porque ninguém agüentava. Sofri o diabo com ele! Era bom porque ensinava tudo. Tinha dia de castrar cem camundongos, tirar supra-renal de cinqüenta, sessenta camundongos com aquele instrumental fino que trouxe da Europa, ferro cirúrgico finíssimo. Mas ele cismou que eu tinha que arranjar camaleão grande, precisava começar a experiência e precisava de camaleão. "Mas como é que eu vou fazer para pegar camaleão, doutor? Vou andar subindo em cima das pedras..." "Você dá um jeito, que eu quero os camaleões." Digo: "Vou no meu guru, é o jeito." "Ô Joaquim, tô com um problema..." "É fácil, é fácil. Amanhã nós vamos naquela pedreira (tinha uma pedreira aqui no porto de Marta-angu), nós vamos na pedreira e vamos pegar muito camaleão." Então, vê a argúcia do Joaquim. Naquele tempo não existia fio de náilon. Mas o rabo de cavalo é como fio de náilon, tem resistência, né, arma. Então fomos lá no rabo do cavalo, cortamos uns fios compridos, ele armou uma laçada. E pegamos umas baratas vivas. Ele amarrou a barata pela cabeça, e botava dentro da laçada, amarrada com linha preta. Fomos lá para a pedreira, e aquilo na ponta de uma vara de bambu bem comprida. Aí o camaleão aparecia lá na pedra, ia arriando, assim, aquela barata - a barata está aqui dentro da laçada — ia encostando perto do camaleão, ele ficava ouriçado, pulava e quando pulava, prendia, ficava preso, o camaleão dançando no laço, né, porque aí ele apertava a laçada. Olha, só no primeiro dia pegamos quarenta e tantos camaleões. "Agora tu não diz a ele como pegou não. Você só diz a ele que os camaleões estão aí." Quando cheguei com aquele caixote, o Thales Martins quase caiu pra trás. "Como é que você conseguiu fazer isso?" Eu disse: "Não sei. O senhor não queria camaleão? Taí o camaleão." Era formidável o Joaquim. Qualquer dificuldade que eu tinha, meu guru me tirava do sufoco.

(Francisco Gomes, 9.12.1985, fitas 1 e 2, lado A, 1a entrevista)

O Venâncio era o mais famoso (auxiliar de Manguinhos). ... Tinha mesmo uma coisa diferente dos outros, ... uma personalidade especial. Era muito senhor de si. Você devia sempre pedir a opinião dele, porque ... era importante, compreende? Ele trabalhava com o dr. Lutz, que era um homem de espírito forte. Venâncio morreu por uma descompensação 
cardíaca, e durante alguns anos ficou praticamente de cama. Morreu numa casinha que tem aqui atrás. Umas duas ou três vezes por semana, depois do almoço, passava lá para bater um papo com ele, e o que contava, as coisas do Instituto que aprendi com ele, eram um negócio tremendo. E o modo de ele encarar a vida, como compreendia cada pessoa! Dizia: "O senhor está enganado, não é assim, não." Tesourava um pouco, compreende? As histórias do Joaquim são muito engraçadas.

(Hugo de Souza Lopes, p. 43, fita 3, lado B, 2 ${ }^{\text {a }}$ entrevista)

O Joaquim tinha um ouvido muito bom. Além disso, era mateiro mesmo. Nasceu no interior de Minas. Foi o Chagas quem o trouxe para cá. Um dia estava o Mário Ventel lá em Angra dos Reis, na fazenda do Travassos, Fazenda da Japuíba. Íamos muito lá para colecionar. Então, o Mário Ventel ouviu alguém bater na porta. Chovia muito, com trovoadas. Era o Joaquim Venâncio, com o dr. Lobo, aqui do hospital, nas costas. O dr. Lobo era um homem forte, meio gordo. O Joaquim pegou-o no meio do caminho, botou-o nas costas e veio andando. Era um homem muito robusto. Também carregava o dr. Lutz nas costas, mas o Lutz era magrinho, era muito fácil.

(Hugo de Souza Lopes, p. 14, fita 4, lado A, 2ª entrevista)

O Joaquim Venâncio era um negão forte, bastante corpulento e, como sapo, perereca, rã se criam nos brejos, carregava não só o Lutz como a Bertha no colo para atravessar esses pântanos. Era um homem que, apesar de ser analfabeto, era muito inteligente, tinha um conhecimento muito grande das coisas. Conhecia rã e perereca pelo canto. Se Lutz dissesse: "Olha, traz aquela perereca", ele ia para o mato e encontrava a espécie no meio de todas as outras. Falo do Joaquim com muito carinho porque era realmente uma pessoa extraordinária. Fui provavelmente o primeiro negro a trabalhar aqui no Instituto, como doutor. Vim para cá como estudante e, num dado momento, percebi a aproximação do Joaquim Venâncio. Vi até que me protegia, eu o sentia assim como uma espécie de anjo da guarda. Ele tinha sempre um respeito, aliás, a família toda do Joaquim respeitava muito a hierarquia. Aqui havia uma disciplina muito rígida. Tinha aquele negócio: o doutor e os outros. Para ele, era a maior coisa o fato de eu ser doutor. Eu freqüentava a casa do Joaquim. A senhora dele, dona Sebastiana, fazia uns biscoitinhos de tapioca que eram um negócio. Um dia, estava conversando com ele e disse: "Ô Joaquim, estou vendo aqui na literatura que um mosquito, um Culex, suga a perereca, e eu nunca encontrei esse bicho, provavelmente nunca vou encontrar." Ele disse: "Ah, já vi, foi até um mosquito descrito pelo Adolpho Lutz." O assunto morreu ali. Não se passaram 15 dias e ele me procurou trazendo o mosquito. Sabia onde existia e foi pegá-lo. 


"Lutz era uma
pessoa muito
querida por todo
mundo, embora
fosse um
secarrão. Mas
sempre tinha uma
palavra curiosa,
pronunciada com
uma prosódia
estrangeira."
estrangeira."
O Lutz começou a estudar também perereca, sapo, essas coisas. E a Bertha continuou o trabalho dessa última fase do Lutz. Ele publicou diversos trabalhos junto com a Bertha. Depois que morreu, Joaquim continuou com a Bertha. Nos trabalhos do Lutz, está lá: "o Joaquim Venâncio apanhou em tal lugar, o Joaquim Venâncio...". E depois que o Lutz morreu, o Instituto recebia muita correspondência endereçada ao "dr. Joaquim Venâncio".

(Sebastião José de Oliveira, 1.9.1986 e 25.2.1986, pp. 24, 26 e 27, fita 5, lado A).

A primeira personagem a me influenciar, e a quem eu me liguei no Instituto, foi o Joaquim Venâncio. Creio que era filho de uma escrava da fazenda de minha avó. Era um caboclo, desse tom um pouco esverdeado que muitos mulatos têm, que não se sabe se vem do índio ou da raça negra, e que um dos meus tios dizia que era uma das características da boa mestiçagem. Joaquim Venâncio era um homem extremamente atraente. Relativamente baixo, era, como se dizia, parrudo, forte e de uma afabilidade extraordinária. Tinha pelo meu pai como por Lutz uma grande adoração. Conta-se até que era utilizado pelo Lutz para pegar mosquitos, de calças abaixadas com as nádegas iluminadas. O conhecimento de Lutz sobre animais brasileiros era uma coisa extraordinária. Principalmente sapos e vermes. Dizia-se que era capaz de identificar não só o gênero, mas a espécie de um sapo pelo seu coaxar. Joaquim Venâncio mostrava-me todos os bichos estranhos que existiam nos armários do laboratório do Lutz. Era um laboratório muito agradável porque não sofria das dificuldades de insolação que os outros experimentavam. Lutz era uma pessoa muito querida por todo mundo, embora fosse um secarrão. Mas sempre tinha uma palavra curiosa, pronunciada com uma prosódia estrangeira... A princípio, eu tinha pavor de encontrá-lo naquelas investidas em seu laboratório. Até que um dia ele apareceu na minha frente. Fiquei sem voz. Mesmo porque não estava sob a tutela de meu anjo protetor, Joaquim Venâncio. Lutz, para meu espanto, começou a falar em alemão comigo, porque sabia que eu falava esse idioma, e no final disse assim: "Espero que um dia você siga os passos de seu pai." E virou as costas, abruptamente, não disse um adeus.

(Carlos Chagas Filho, 18.2.1987 a 2.9.1987, p. 16, fita 5, lado B; p. 1, fita 6, lado A, 3르 entrevista) 


\section{Em família}

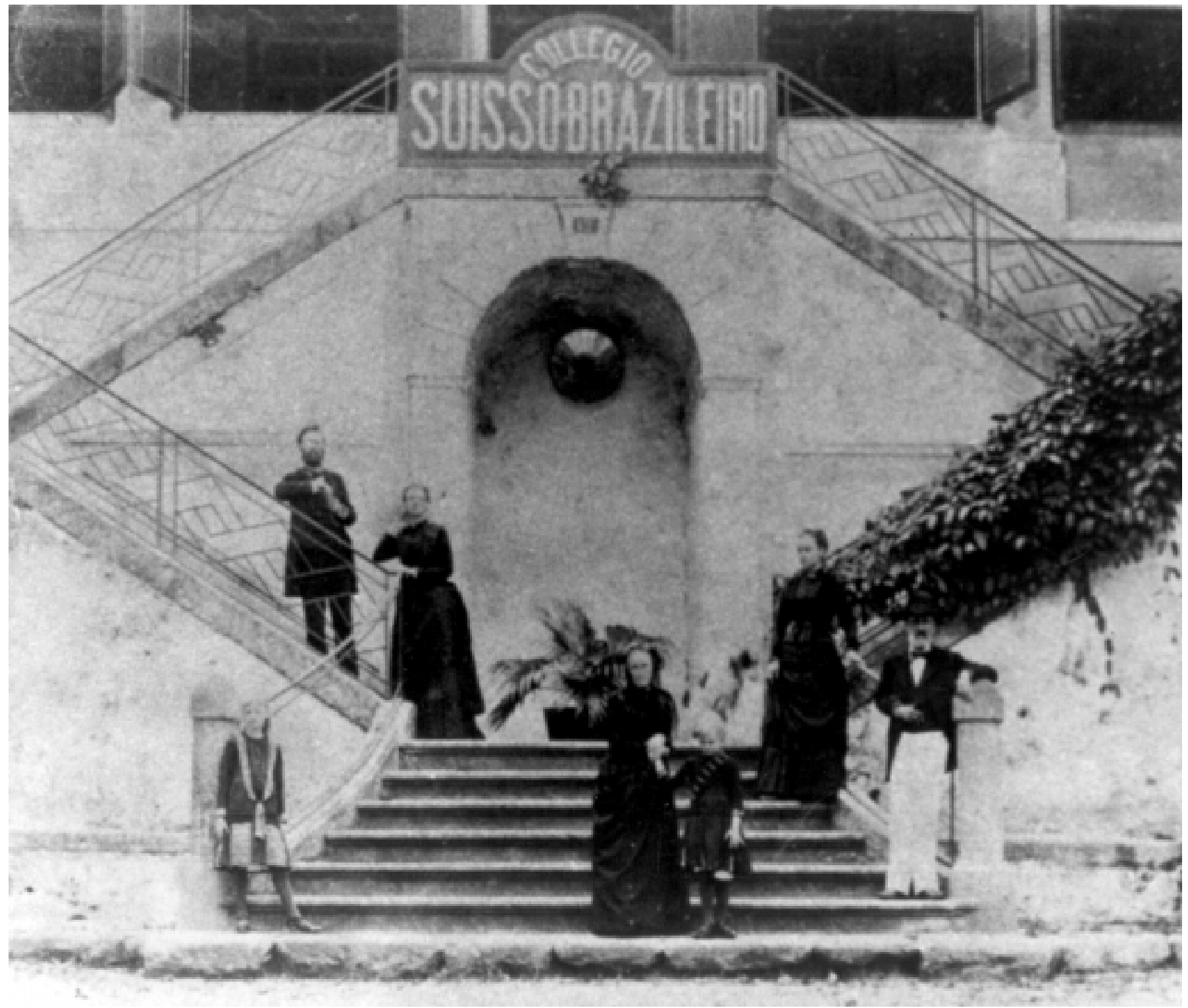

Fotografia tirada na década de 1880. Família de Adolpho Lutz na escadaria do prédio que servia de residência e de sede do Colégio Suisso Brazileiro, na rua da Princeza Imperial, 33, no bairro do Catete, onde funcionou até 1886, ou rua Farani, 12, em Botafogo, para onde se transferiu em 1887. Em primeiro plano, a mãe de Adolpho Lutz, Matilde Oberteuffer Lutz, segura a mão da neta, Gertrude Lutz Warnstorff, nascida em 24 de junho de1880. À direita, Gustav, pai do cientista, e à esquerda, a outra neta de Matilde, Paula Elisabeth Lutz Warnstorff. Em segundo plano, à direita, a segunda irmã de Adolpho Lutz, que herdou o nome da mãe (Matilde), e, à esquerda, Maria Elisabeth, a irmã primogênita, mãe das duas crianças. A seu lado, um dos irmãos, Gustav ou William Robert. Casa de Oswaldo Cruz/Fiocruz, Departamento de Arquivo e Documentação, Setor Iconográfico, Série Personalidades, Pasta IOC (P) LUTZ, A-7. Foto existente também no Instituto Adolpho Lutz. 


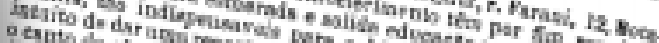

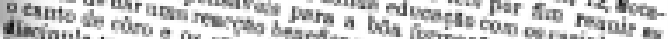

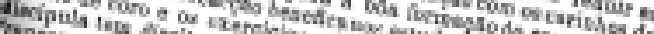

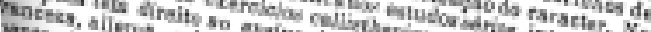

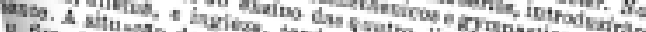

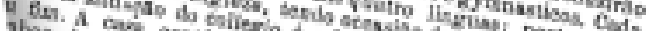

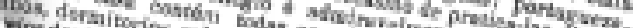

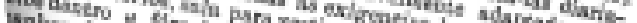

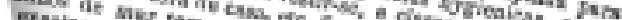

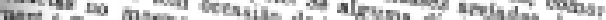

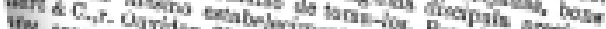

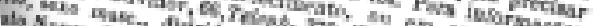

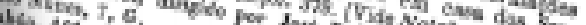

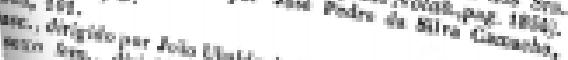

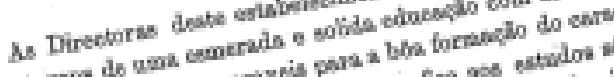

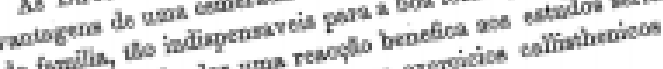

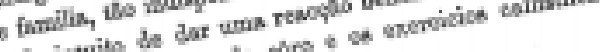

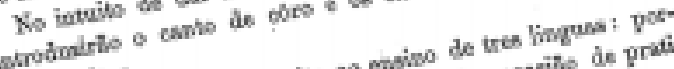
crimastitot.

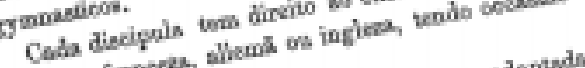

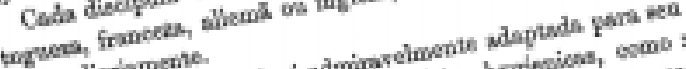

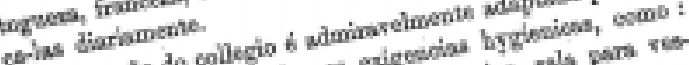

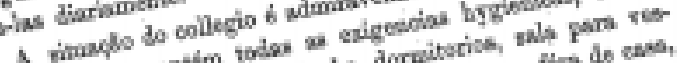

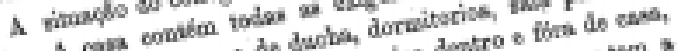

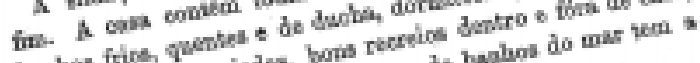

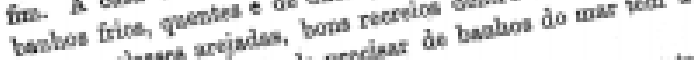

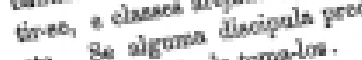

an mestion entabelodimetion

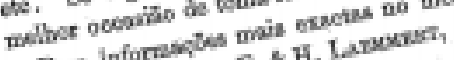

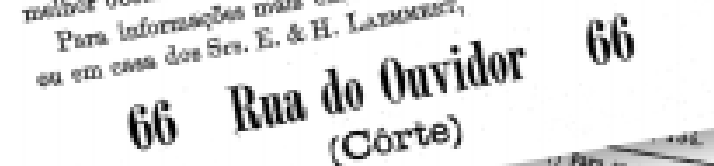

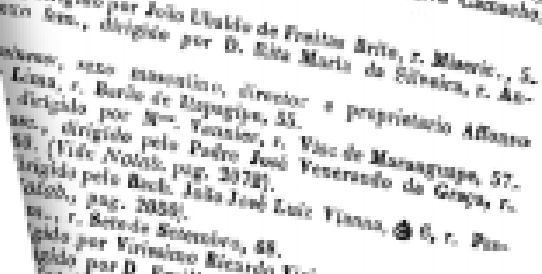

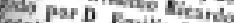
(Corte)

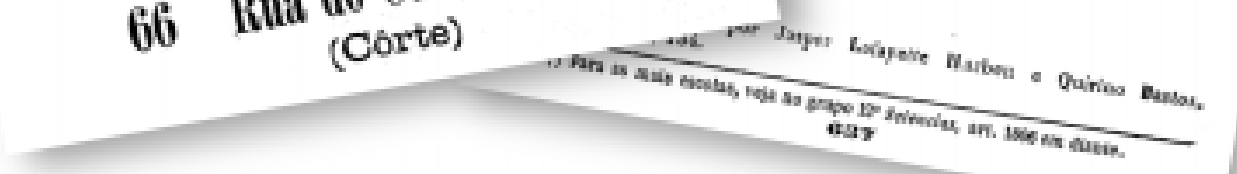

Anúncios publicados no Almanaque Laemmert em 1881, 1882 e 1889

(http://wwwcrl.uchicago.edu/info/brazil/pindex.htm). 


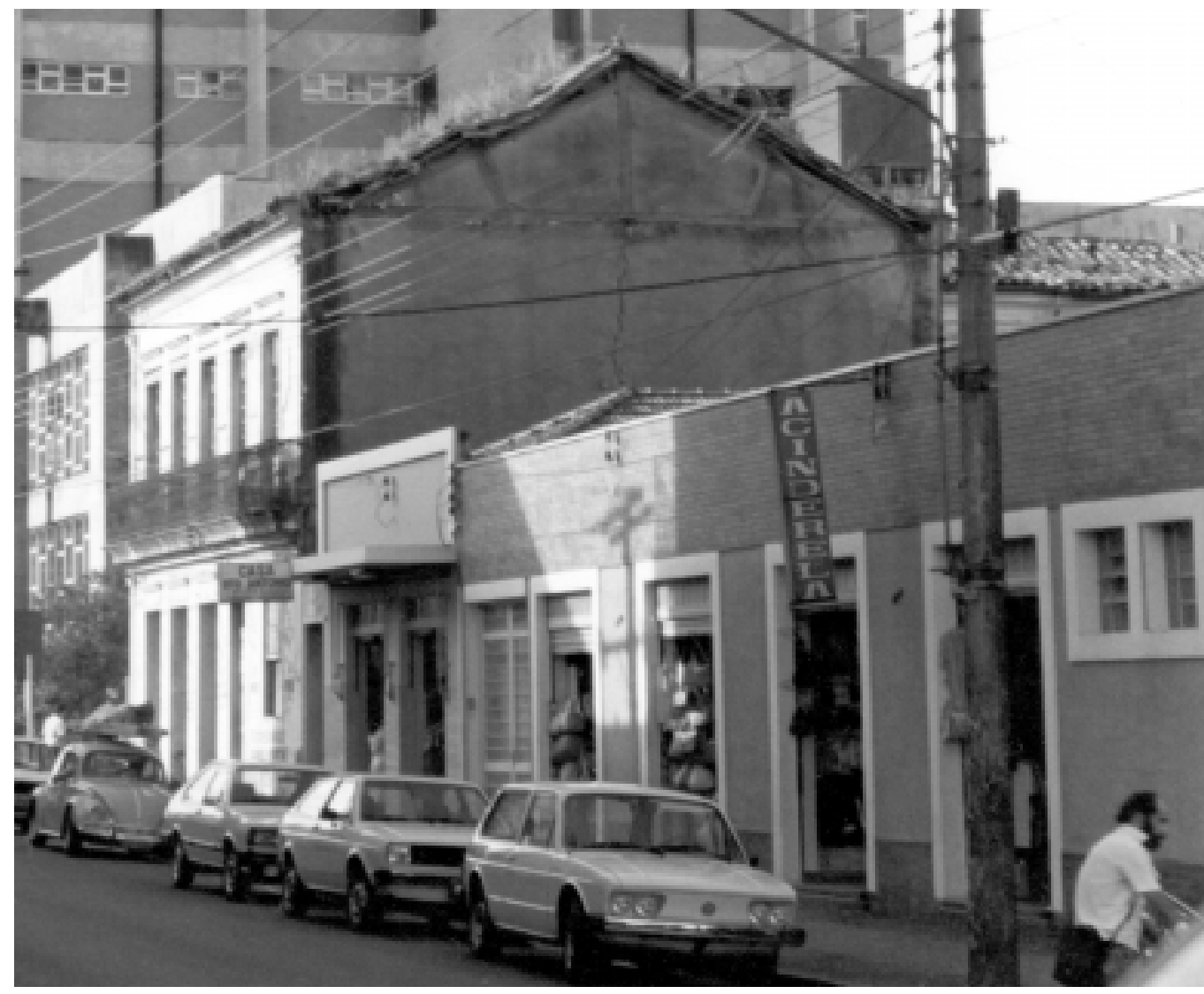

Sobrado onde residiu Adolpho Lutz em Limeira (SP). Imagem

registrada por Eduardo Cruz em abril de 1986, às vésperas da demolição do prédio. Instituto Adolpho Luz.

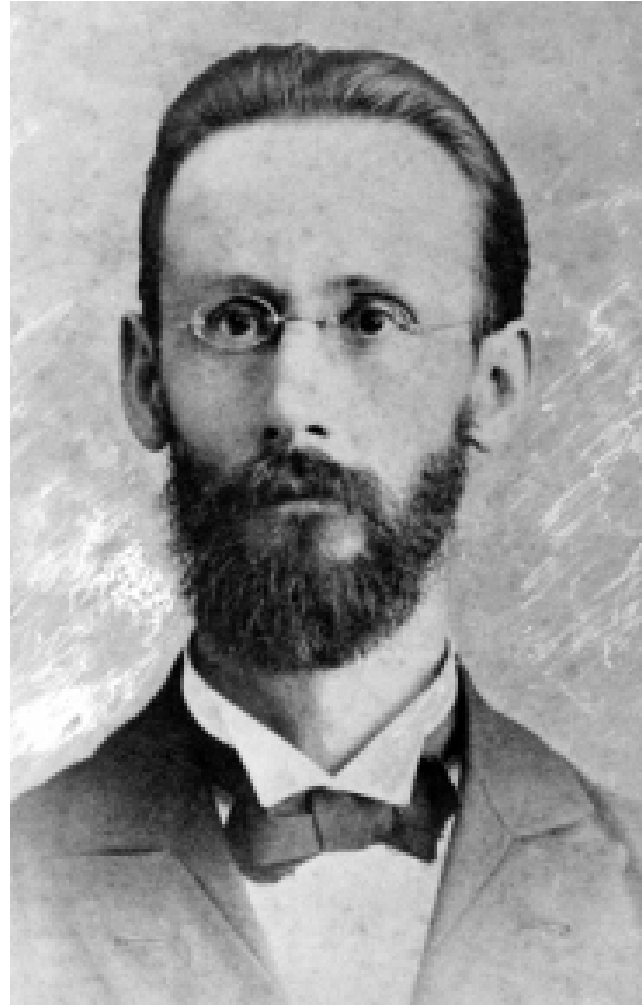

Adolpho Lutz em foto dos anos 1880 , quando começava a exercer a clínica no interior de São Paulo. Museu Emílio Ribas.

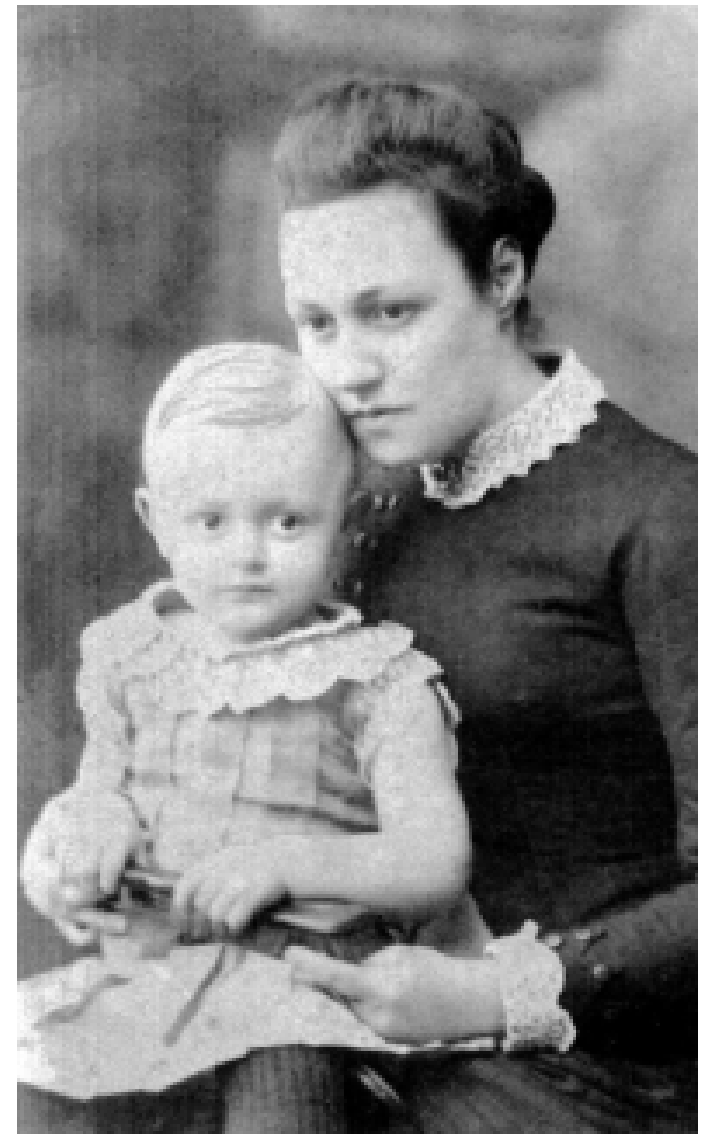

Helena Lutz Luce, a irmã de Adolpho Lutz que residia em Limeira, com o filho Gottfried Wilhelm Luce, nascido em 24 de agosto de 1884. Foto tirada em Campinas (SP), em 20 de junho de 1886, na

Photographia

Rozén, Nickelsen \& Ferreira, situada na rua Direita, 48. Acervo Margareta Luce. 


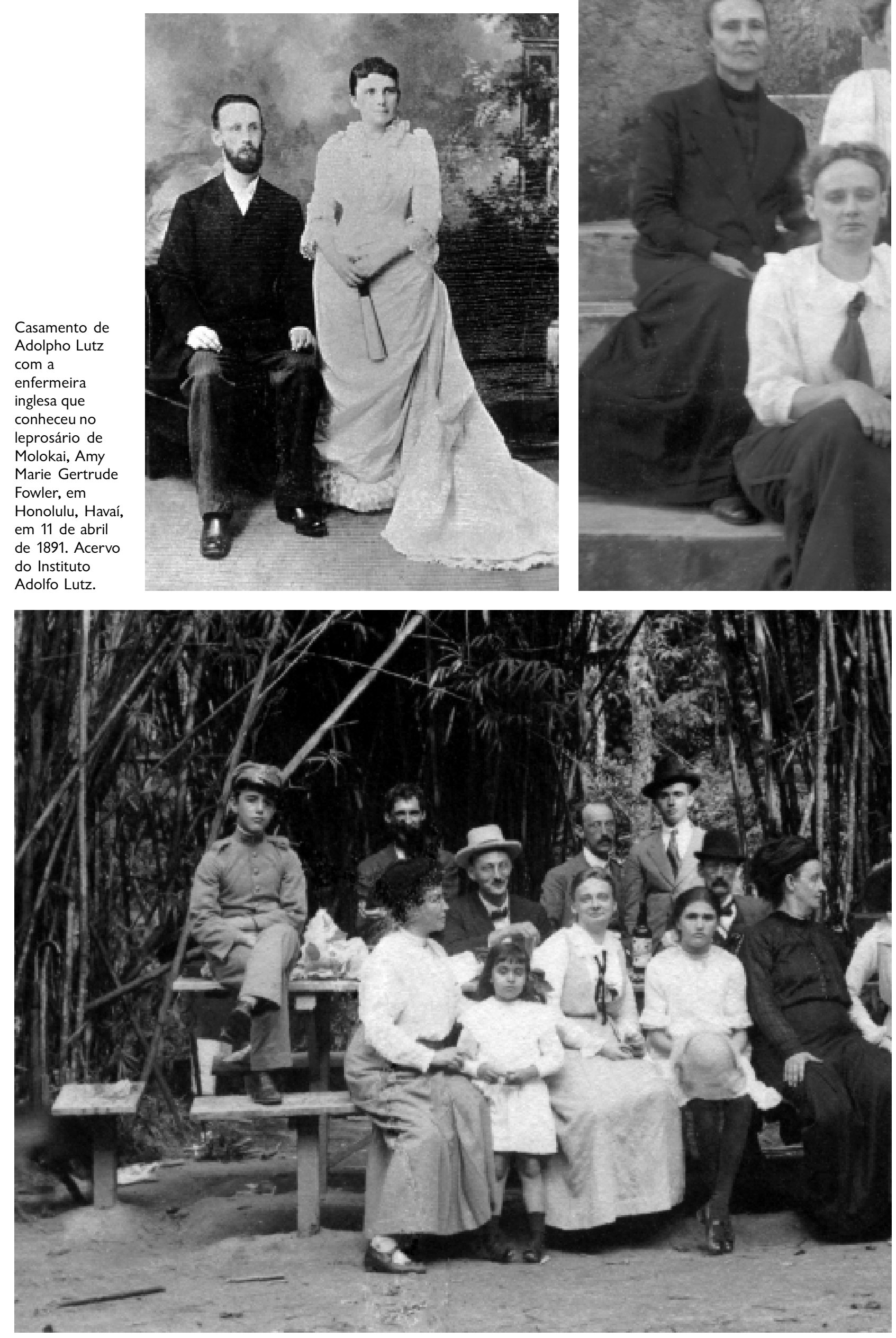



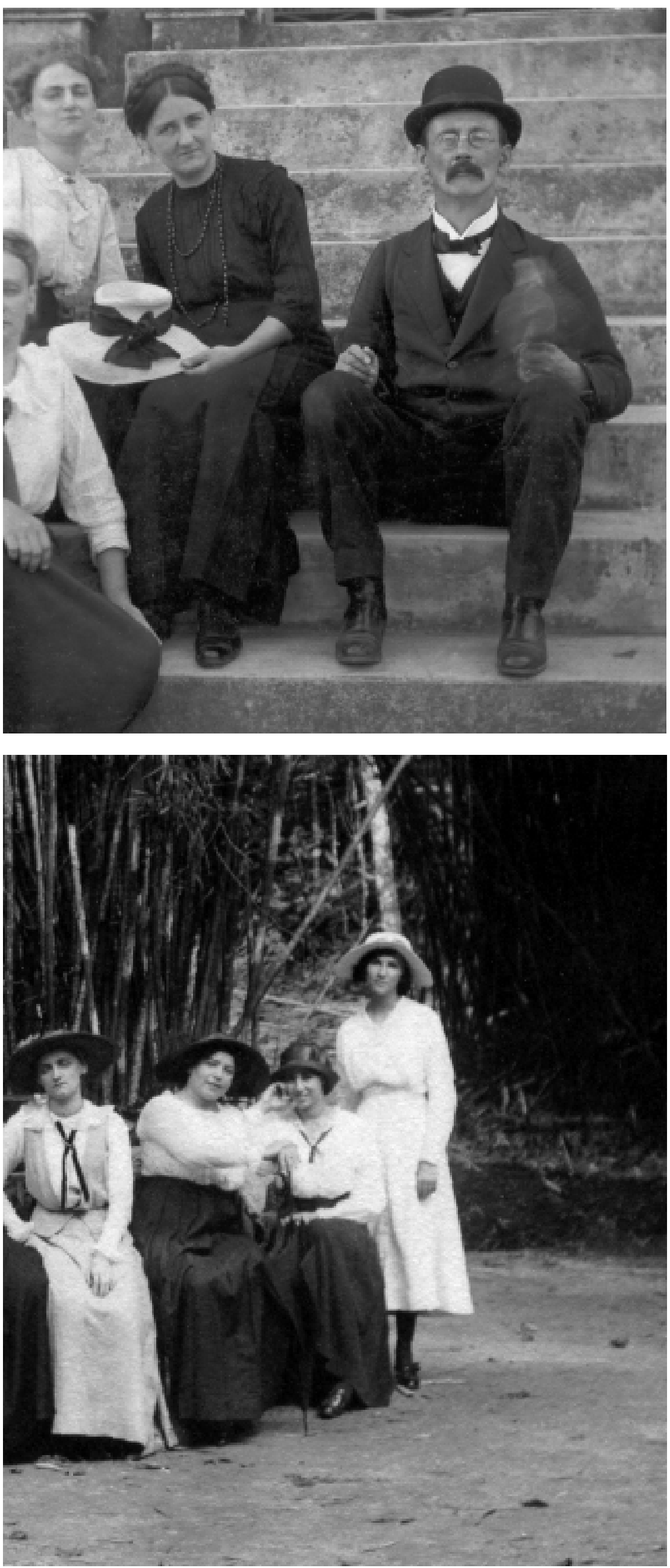

Adolpho Lutz tem a seu lado, em trajes negros, Maria Elisabeth Lutz Warnstorff e as duas filhas desta, com blusas claras, Paula Elisabeth e, acima dela, a caçula Gertrude. À esquerda, trajando negro também, Matilde, irmã de Adolpho e Maria Elisabeth (cujo nome, aportuguesado, ficou sendo dona Isabel). Foto tirada, provavelmente, no começo do século $X X$, numa das visitas ao Rio de Janeiro. Pode ter sido em 1902, quando veio buscar Aedes aegypti para as experiências realizadas em seguida, em São Paulo, com o fim de demonstrar a transmissão da febre amarela por mosquitos; ou em 1908, quando Luz regressou à capital federal para organizar a mostra do Instituto Bacteriológico na exposição comemorativa do centenário da abertura dos portos, realizada na Urca. Acervo Margareta Luce.

Família Lutz reunida no Jardim Botânico do Rio de Janeiro, na década de 1910. Adolpho Lutz está sentado atrás da irmã mais velha, Maria Elisabeth (Isabel) Lutz Warnstorff, que tem, à sua esquerda, a filha Gertrude, e à sua direita, uma das filhas do sorridente William Robert, de chapéu branco na fila de trás. $\mathrm{Na}$ foto estão duas outras filhas de 'tio Will', de saias pretas, na extremidade direita do banco, e, quem sabe, outros dos seis filhos que o cervejeiro teve com Maria Francisca Marinho Lutz, falecida em 1903, de tuberculose. Entre Adolpho e William, está o sobrinho, Godofredo Luce, filho da terceira irmã do cientista, Helena, que se casou em 1881 com Gottfried Wilhelm Luce. Bem em frente a William estão Paula Elisabeth (com roupa igual à da irmã Gertrude), a menina Lúcia, filha de um empregado da família que ela criou, e Benedita, a cozinheira do Colégio Lutz. Segundo Ortigão (ver seção ‘Depoimento'), Lúcia nasceu por volta de 1912. A idade provável da menina e a ausência dos filhos e da esposa de Adolpho Lutz sugerem que a foto tenha sido tirada durante a Primeira Guerra Mundial, quando Bertha, Gualter e Amy Lutz ficaram retidos na França. A fotografia pertence ao acervo de Margareta Luce, filha de Godofredo. 


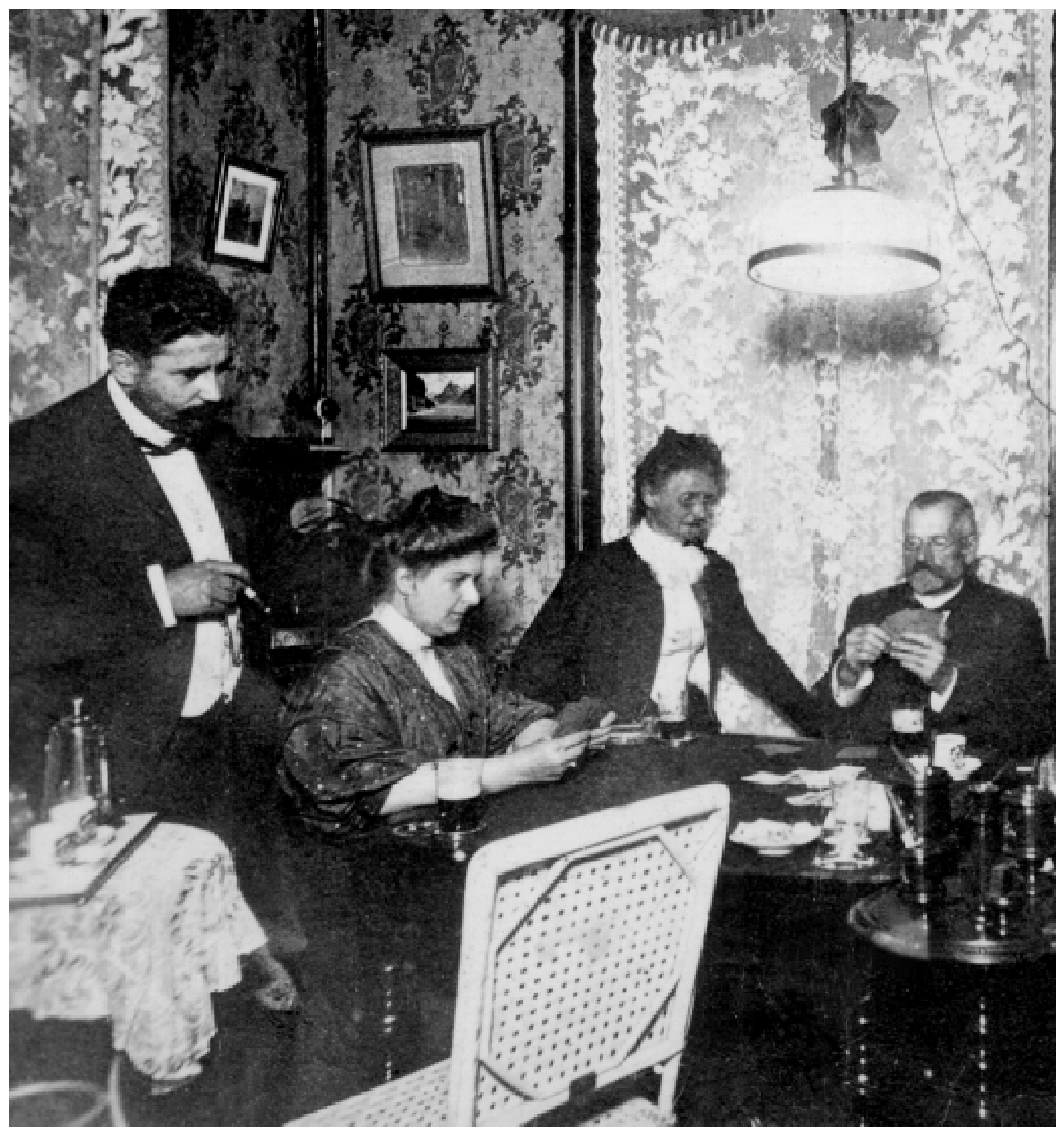

Segundo anotação no verso da foto, Adolpho Lutz joga cartas com o sr. Hottniger, sua sogra, Jacques Kesselring e a filha, a senhorita Schroeder. São Paulo, começo do século.

BRMN. Arquivo. Fundo Adolpho Lutz. 

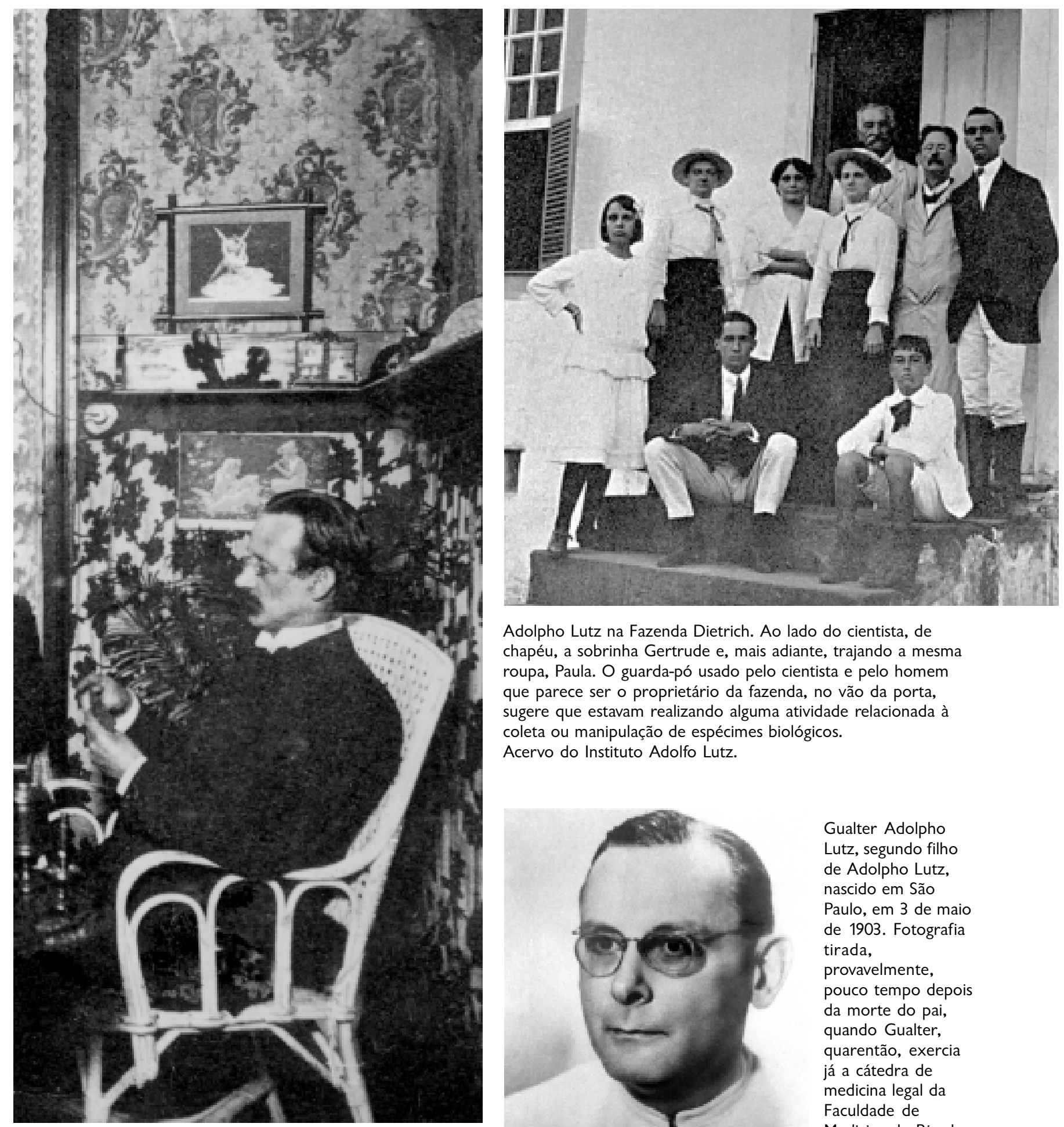

Adolpho Lutz na Fazenda Dietrich. Ao lado do cientista, de chapéu, a sobrinha Gertrude e, mais adiante, trajando a mesma roupa, Paula. O guarda-pó usado pelo cientista e pelo homem que parece ser o proprietário da fazenda, no vão da porta, sugere que estavam realizando alguma atividade relacionada à coleta ou manipulação de espécimes biológicos.

Acervo do Instituto Adolfo Lutz.

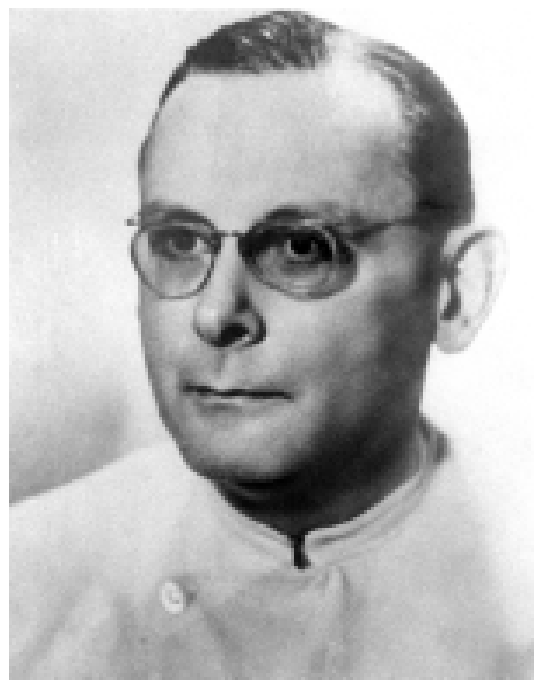

Gualter Adolpho Lutz, segundo filho de Adolpho Lutz, nascido em São Paulo, em 3 de maio de 1903. Fotografia tirada, provavelmente, pouco tempo depois da morte do pai, quando Gualter, quarentão, exercia já a cátedra de medicina legal da Faculdade de Medicina do Rio de Janeiro. Foto cedida por Charlotte Emmerich. 


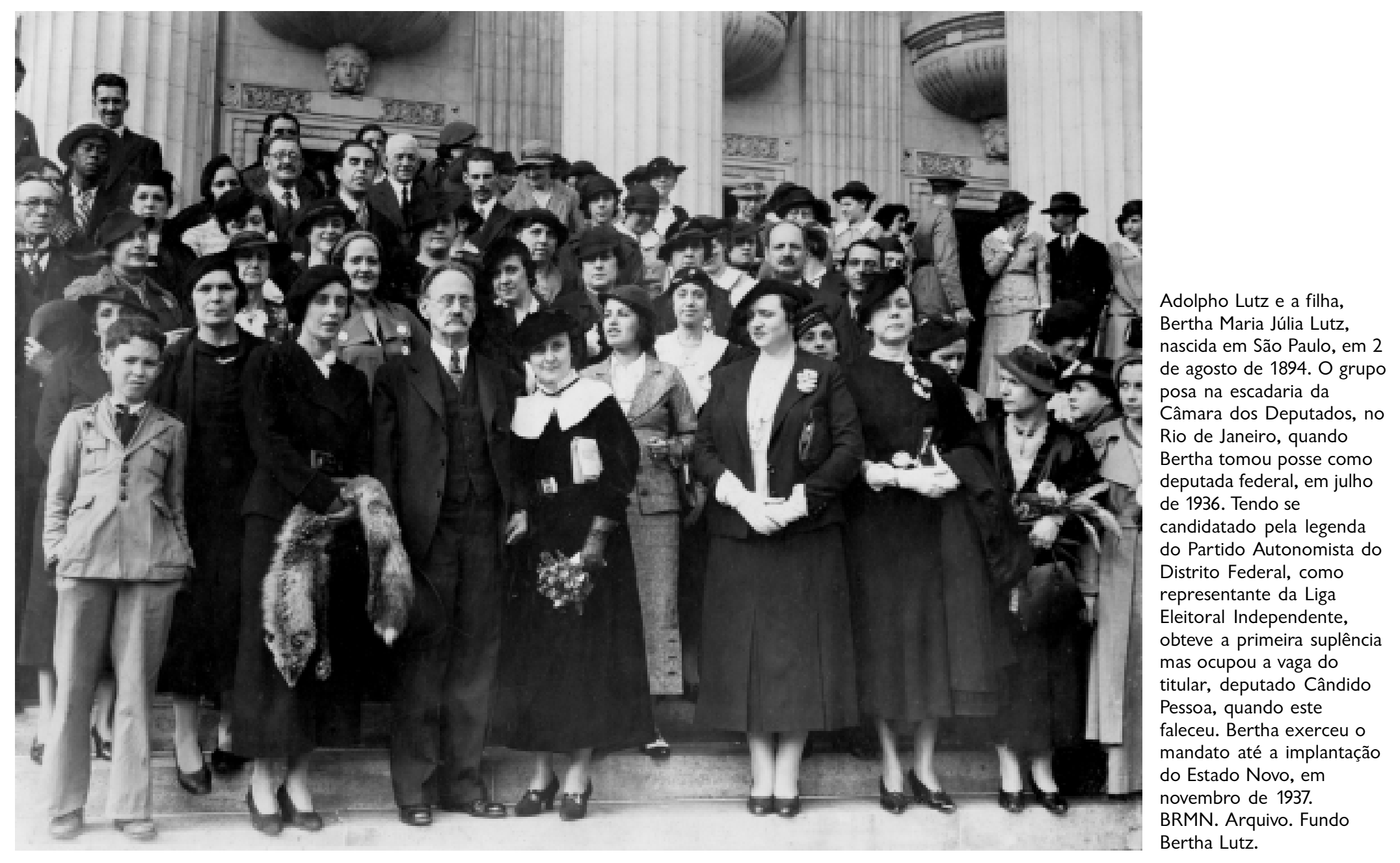




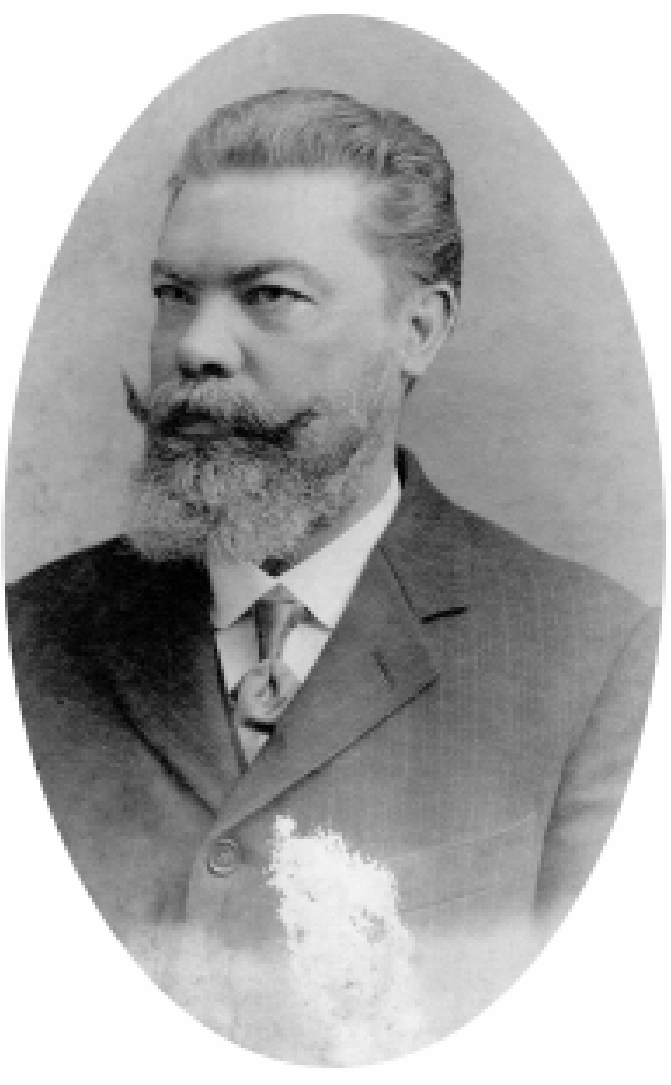

Emílio Ribas.

Museu Emílio Ribas.

\section{Em São Paulo}

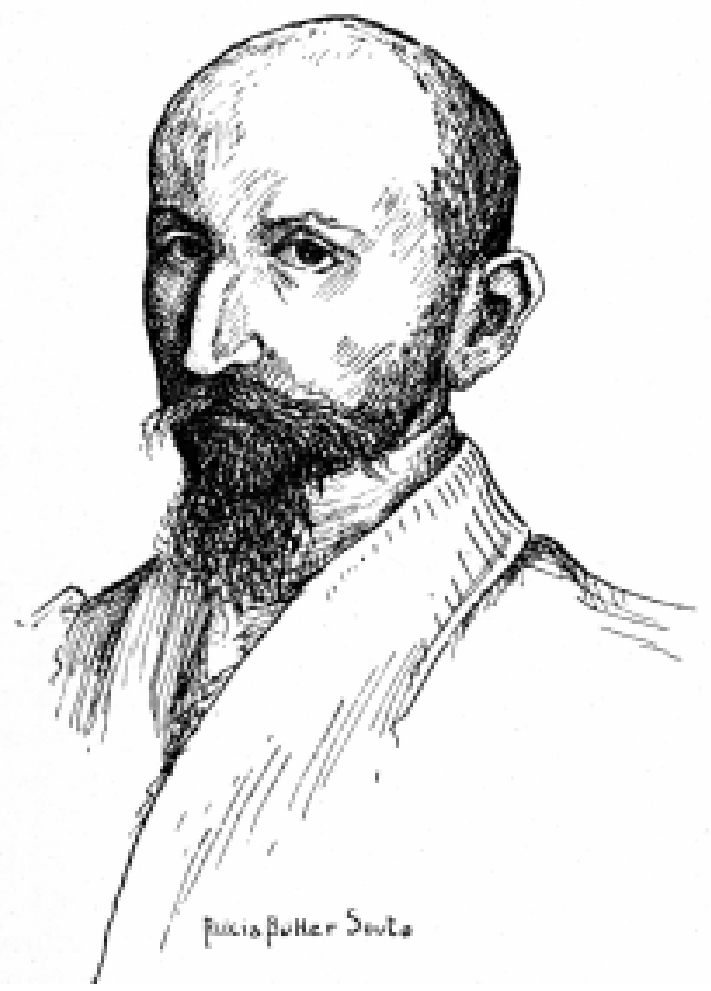

Felix Alexander Le Dantec, em desenho de Alicia Büller Souto. Museu Emílio Ribas.

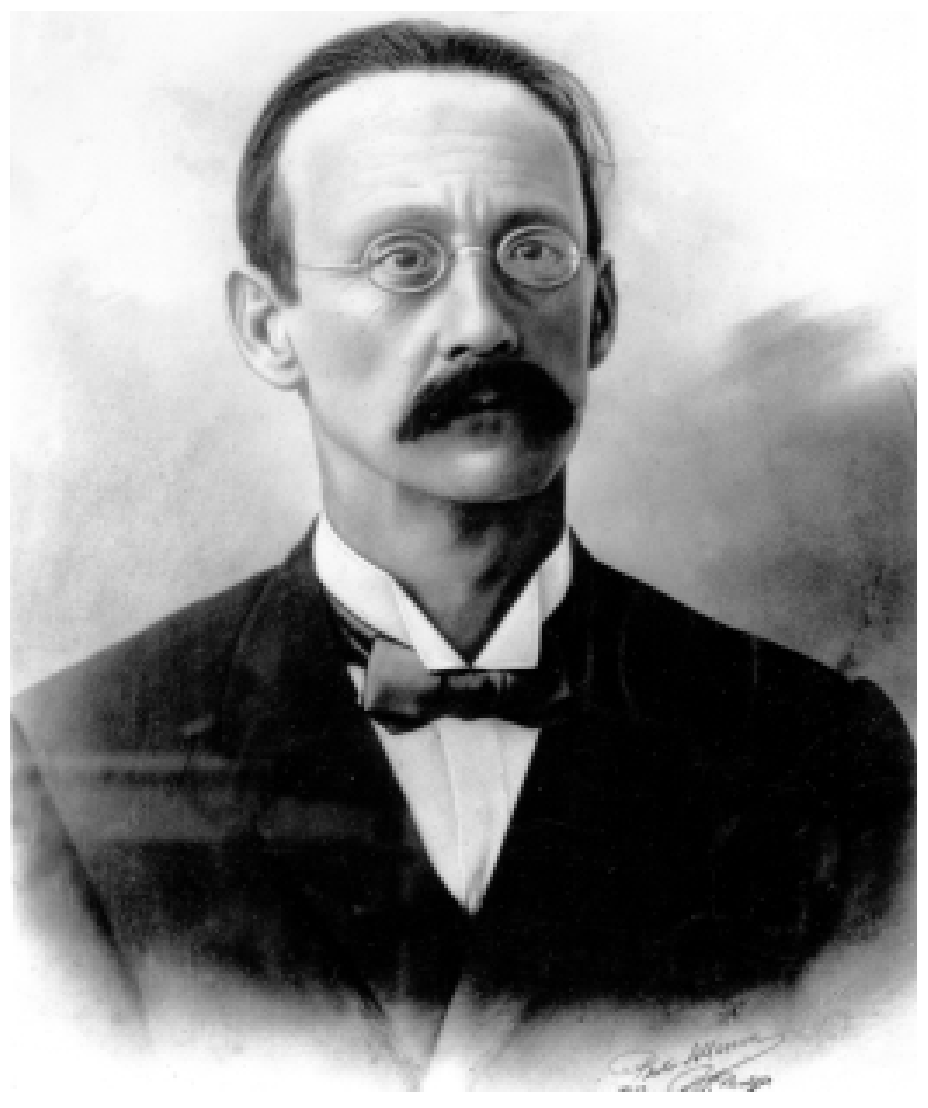

Adolpho Lutz na década

de 1890 , à época em

que chefiava o Instituto

Bacteriológico de

São Paulo.

Museu Emílio Ribas. 


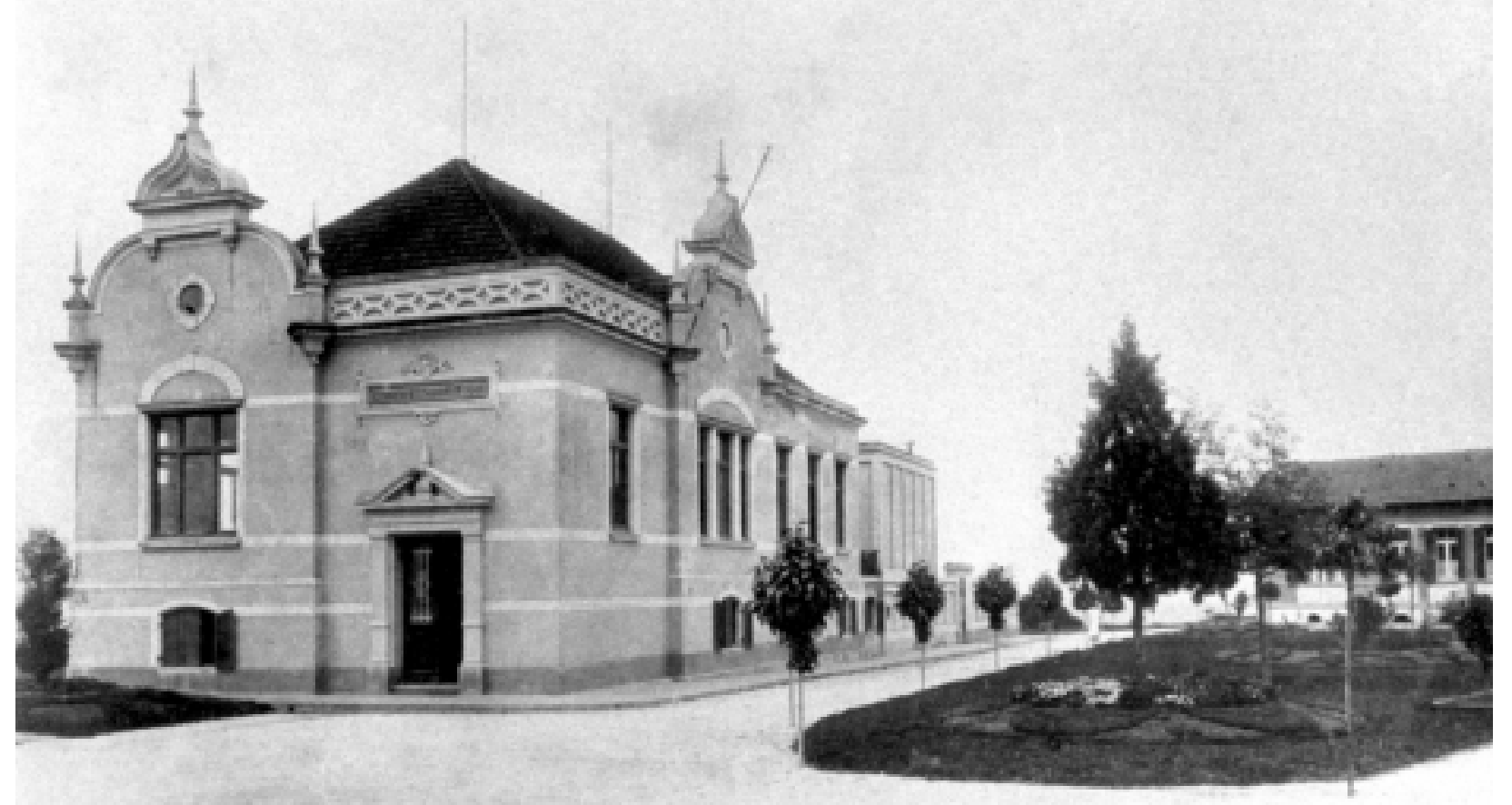

Vista lateral do Instituto Bacteriológico de São Paulo, vendo-se ao fundo um dos pavilhões do Hospital de Isolamento. Algumas Instalações do Serviço Sanitário de São Paulo. São Paulo, Vanorden \& Co., 1905. Museu Emílio Ribas.

Um laboratório do Instituto

Bacteriológico de São Paulo, vendose, em primeiro plano, Adolpho Lutz, ao microscópio, Adolpho Lindemberg, Theodoro Bayma e Carlos Meyer. Esta é uma das raríssimas fotografias de Adolpho Lutz da época em que chefiou o Instituto Bacteriológico de São Paulo. Ele tinha tamanha aversão à publicidade que são raras as imagens que documentam suas atividades na saúde pública no período, não obstante fossem elas intensas.

Museu Emílio Ribas.

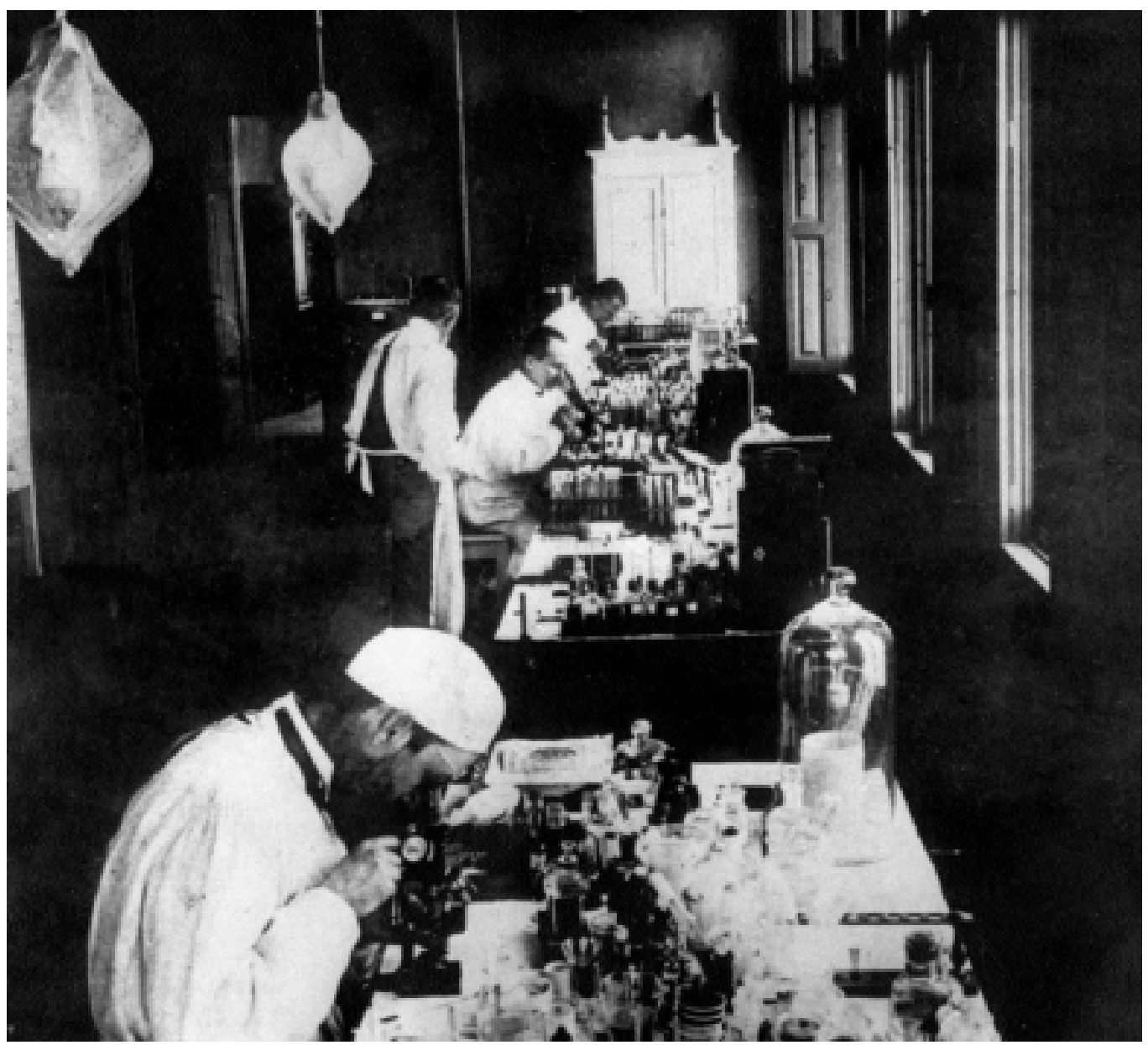




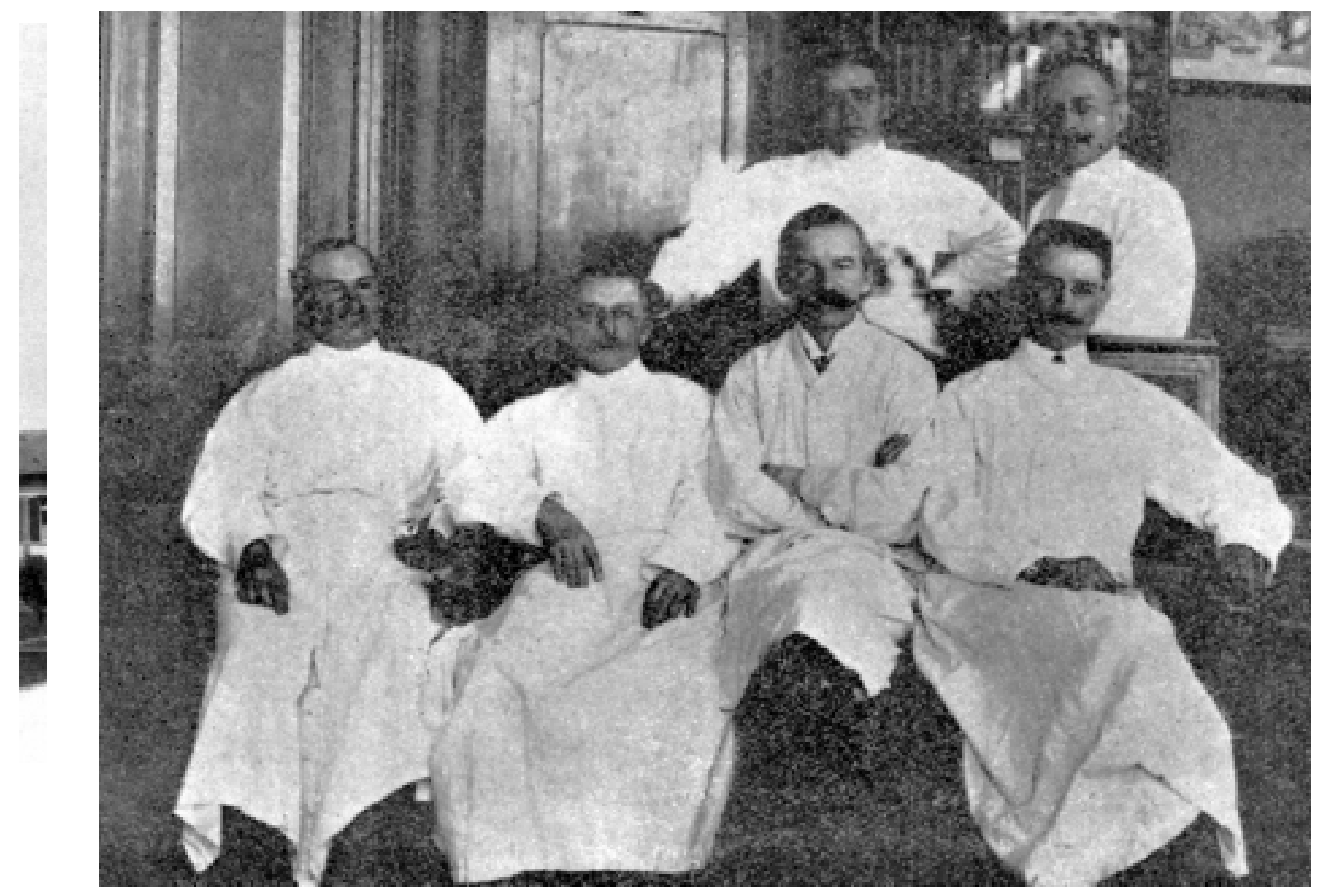

Instituto Bacteriológico. Sentados, da esquerda para a direita, Theodoro Bayma, Carlos Meyer, Martin Ficker e Pais Azevedo. Em pé: Otávio Viega e Adolpho Lindemberg. Museu Emilio Ribas.

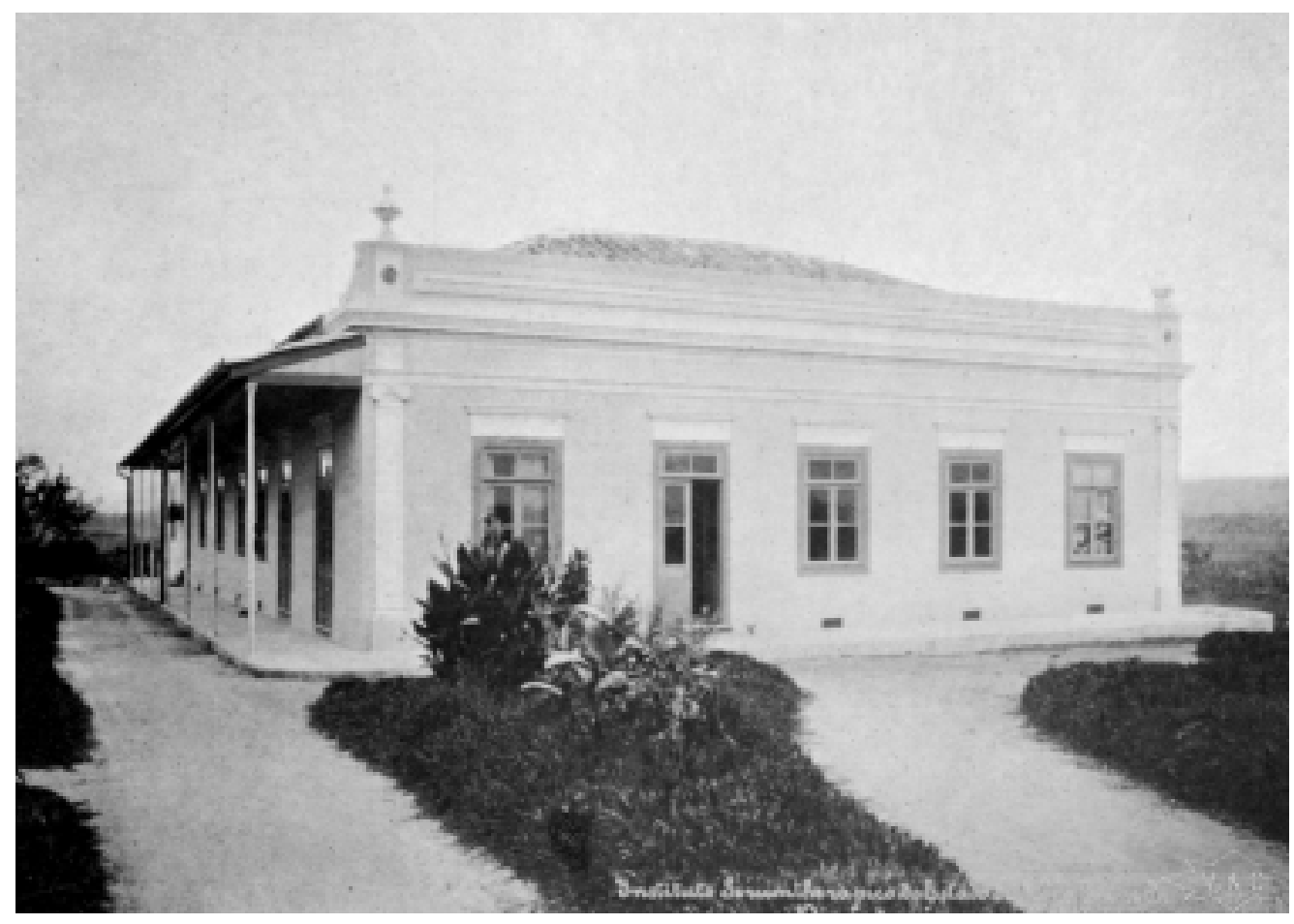

Prédio da

diretoria do Instituto

Soroterápico do estado, o

Butantan.

Algumas

Instalações do Serviço Sanitário de São Paulo. São Paulo, Vanorden \& Co., 1905. Museu Emílio Ribas. 
Instituto

Butantan.

Gaiolas de

cobras e

extração do

veneno.

Algumas

Instalações do

Serviço

Sanitário de

São Paulo. São

Paulo,

Vanorden \&

Co., 1905.

Museu Emílio

Ribas.

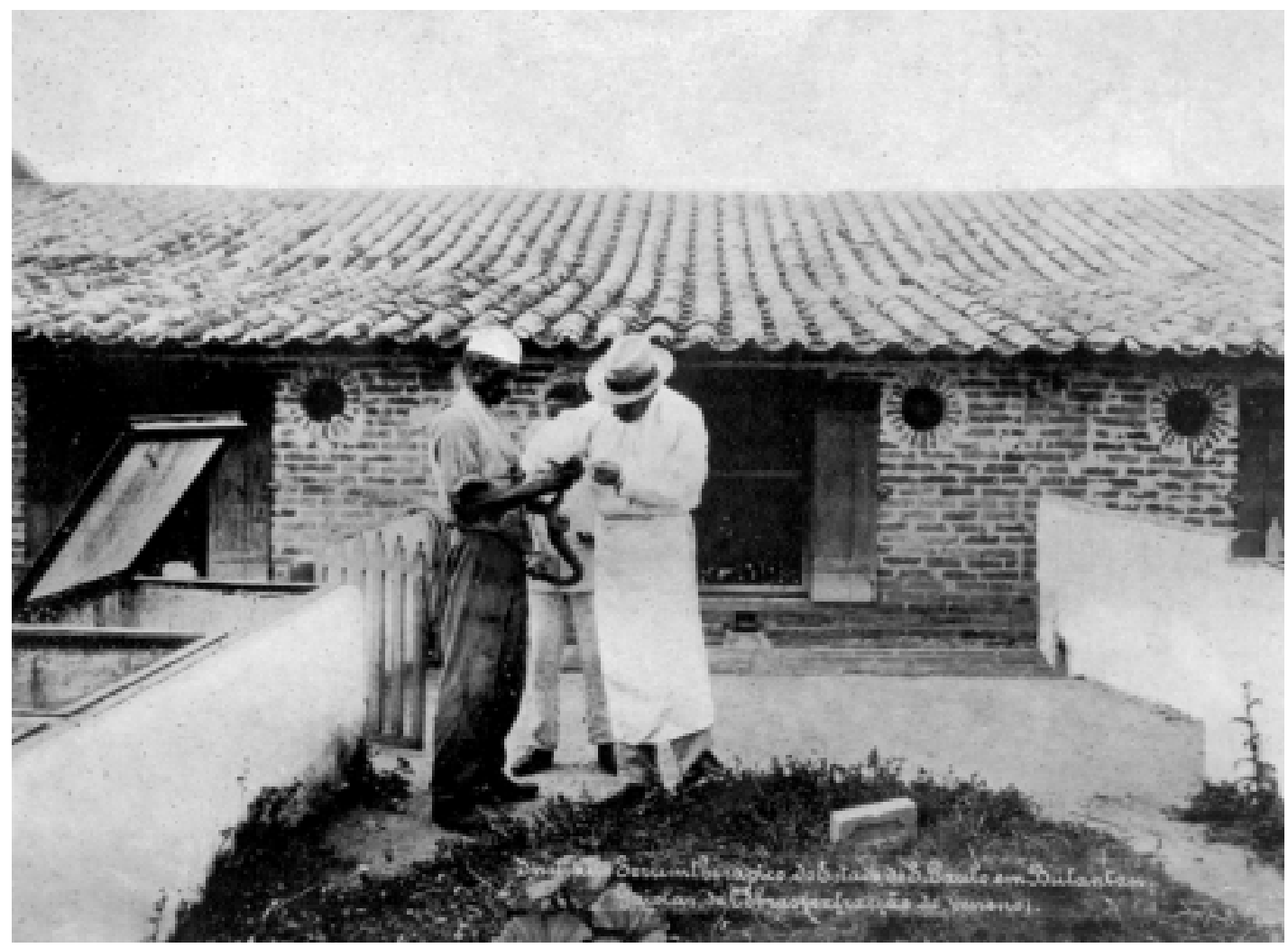

Vista

posterior da

cocheira-

enfermaria

do Butantan.

Algumas

Instalações do

Serviço

Sanitário de

São Paulo.

São Paulo,

Vanorden \&

Co., 1905

Museu Emílio

Ribas.

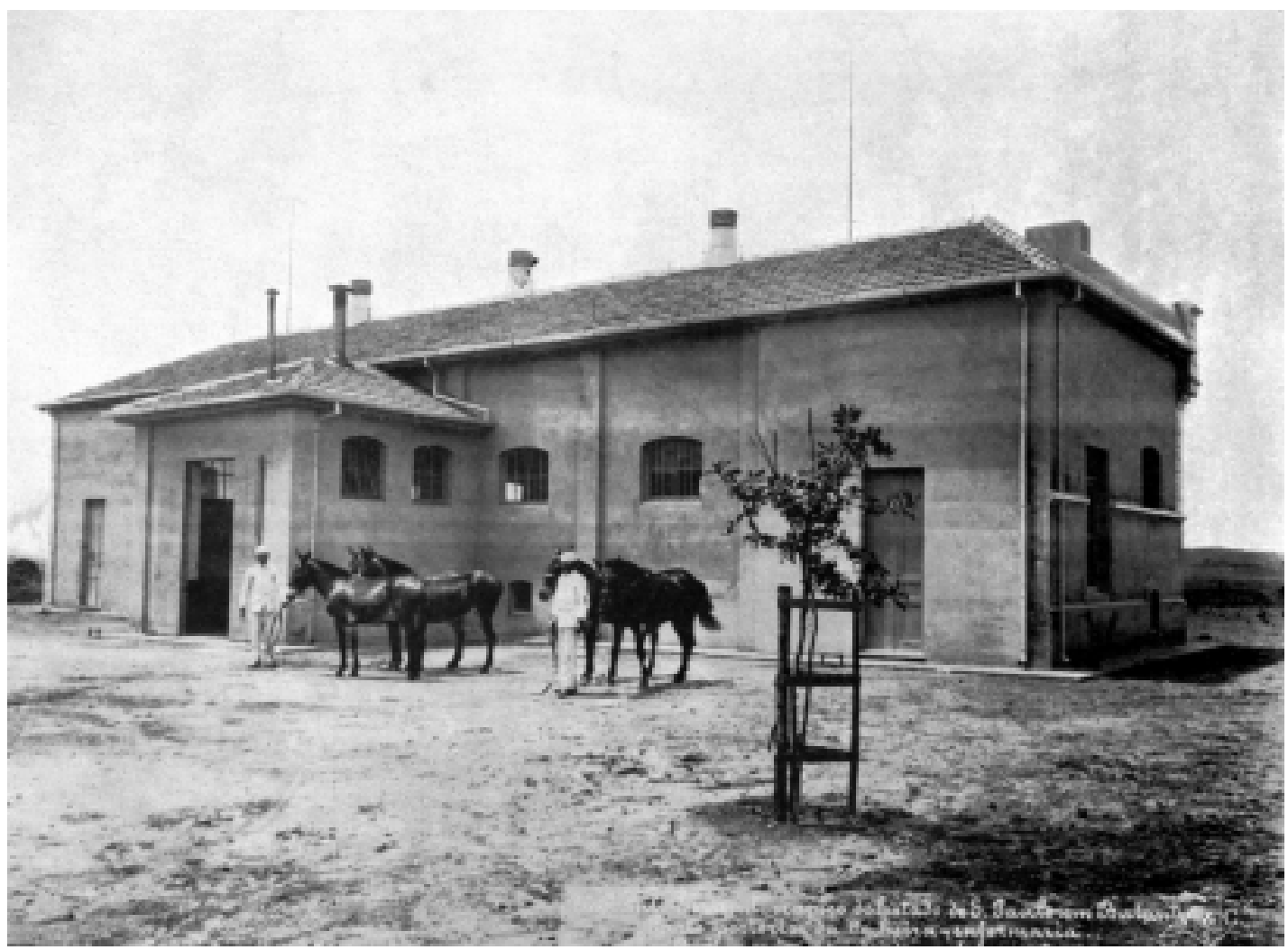



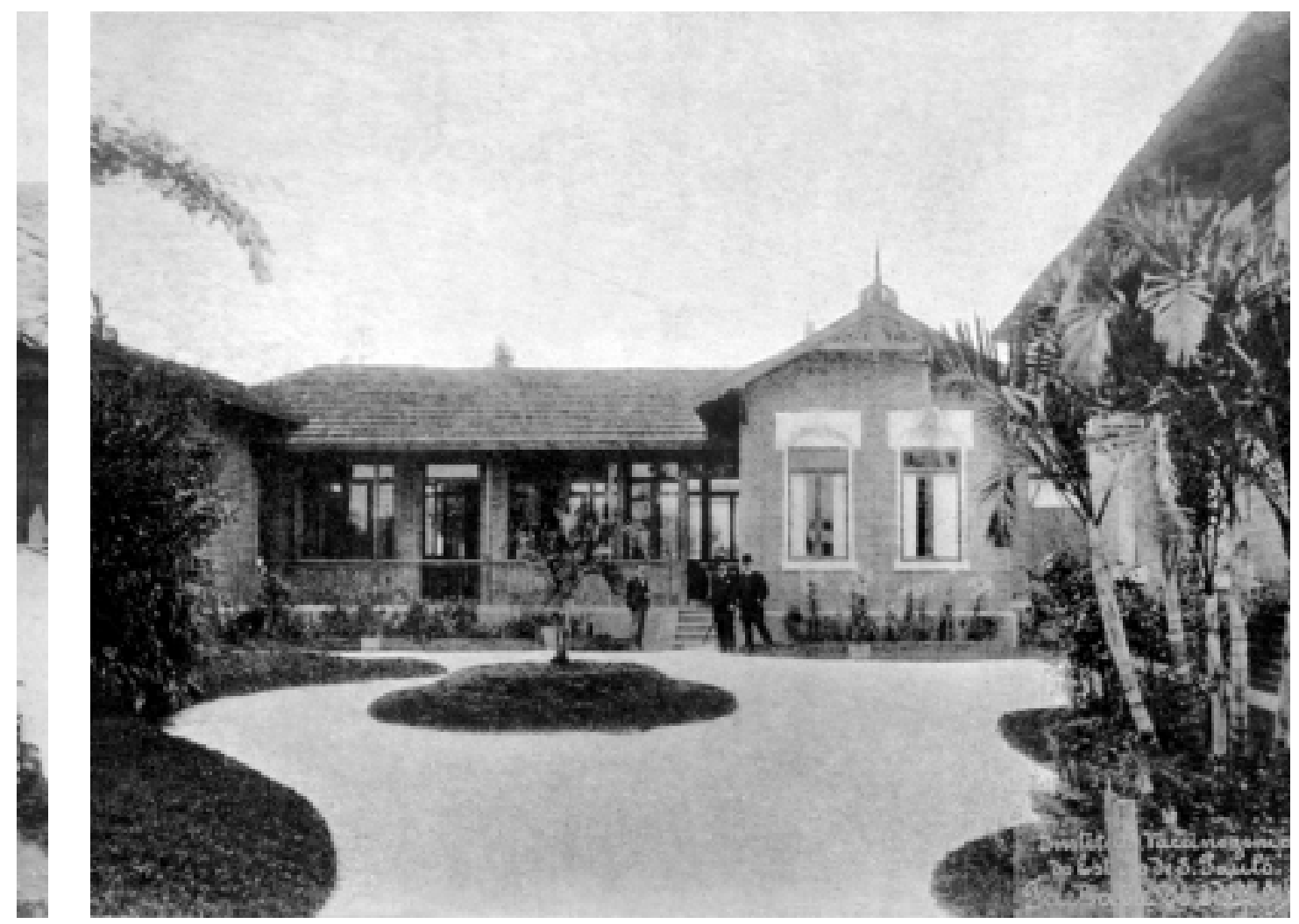

Fachada

lateral do

Instituto

Vacinogênico,

onde era

fabricada e

aplicada a

vacina

antivariólica.

Algumas

Instalações do

Serviço

Sanitário de

São Paulo. São

Paulo,

Vanorden \&

Co., 1905.

Museu Emílio

Ribas.

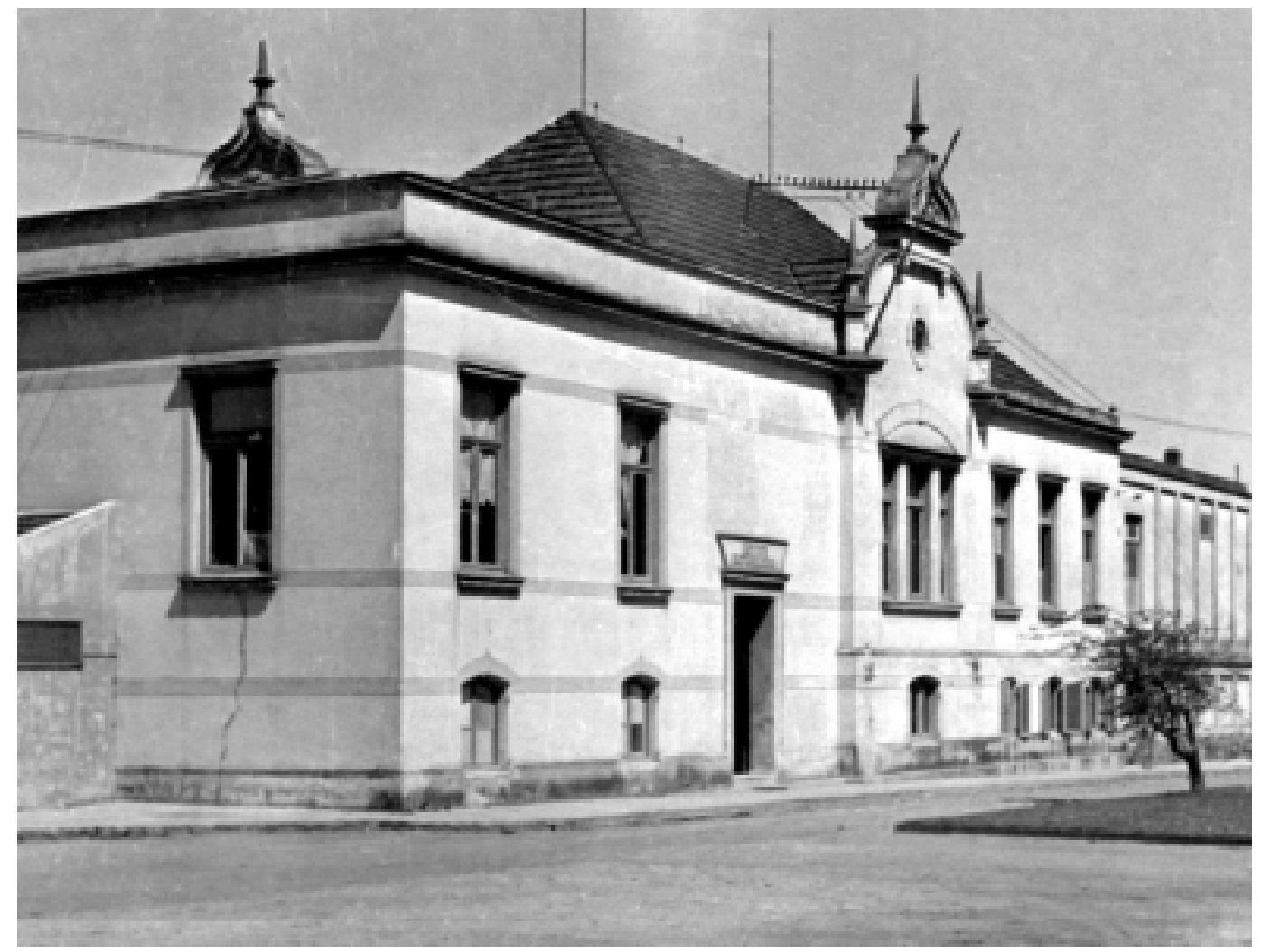

Tomada do

Desinfectório

Central, que

atualmente

abriga o Museu

Emílio Ribas.

Algumas

Instalações do

Serviço

Sanitário de São

Paulo. São

Paulo,

Vanorden \&

Co., 1905.

Museu Emílio

Ribas. 


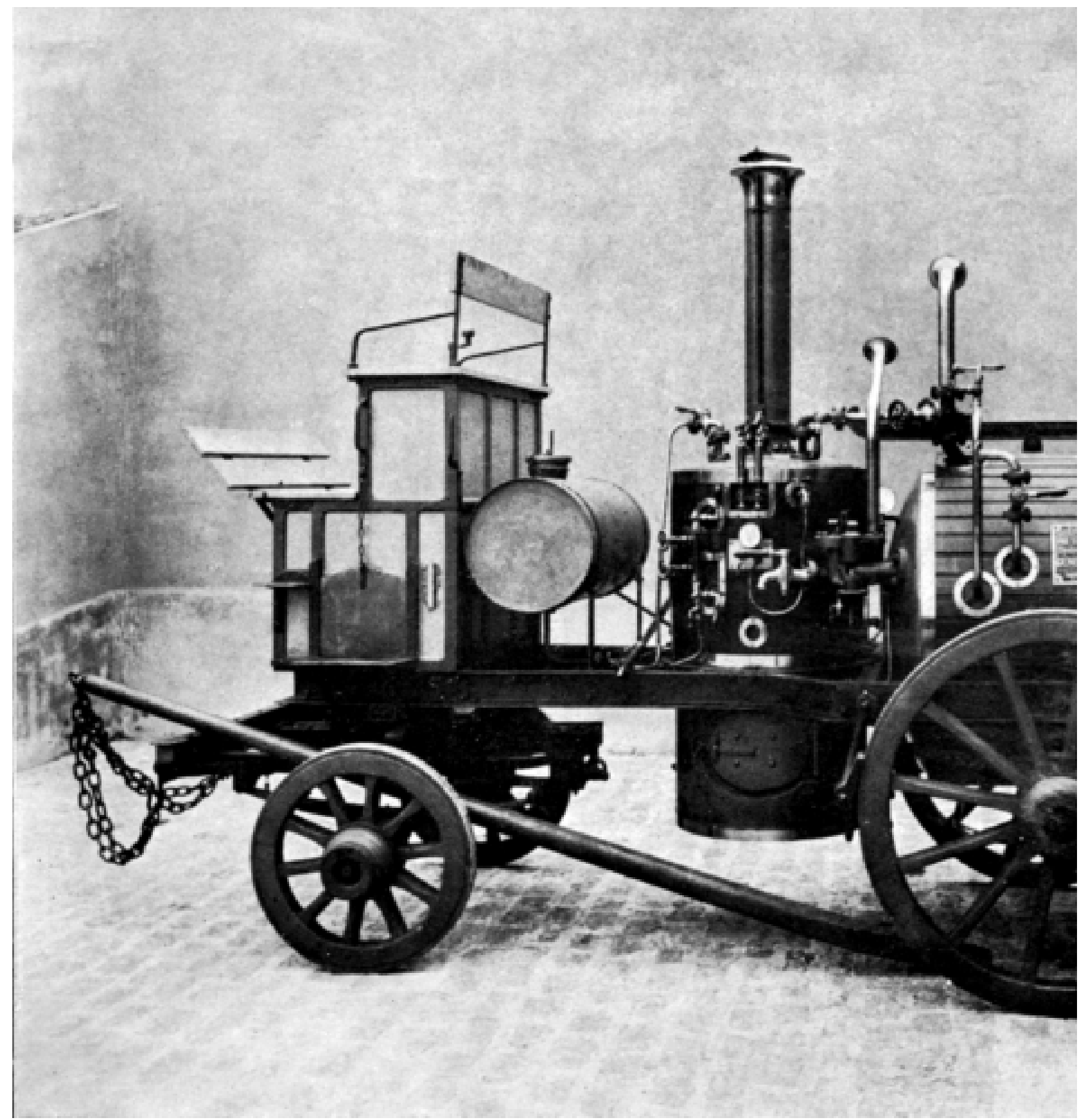

Desinfectório Central. Estufa locomóvel da Geneste \& Herscher. Algumas Instalações do Serviço Sanitário de São Paulo. São Paulo, Vanorden \& Co., 1905. Museu Emílio Ribas. 

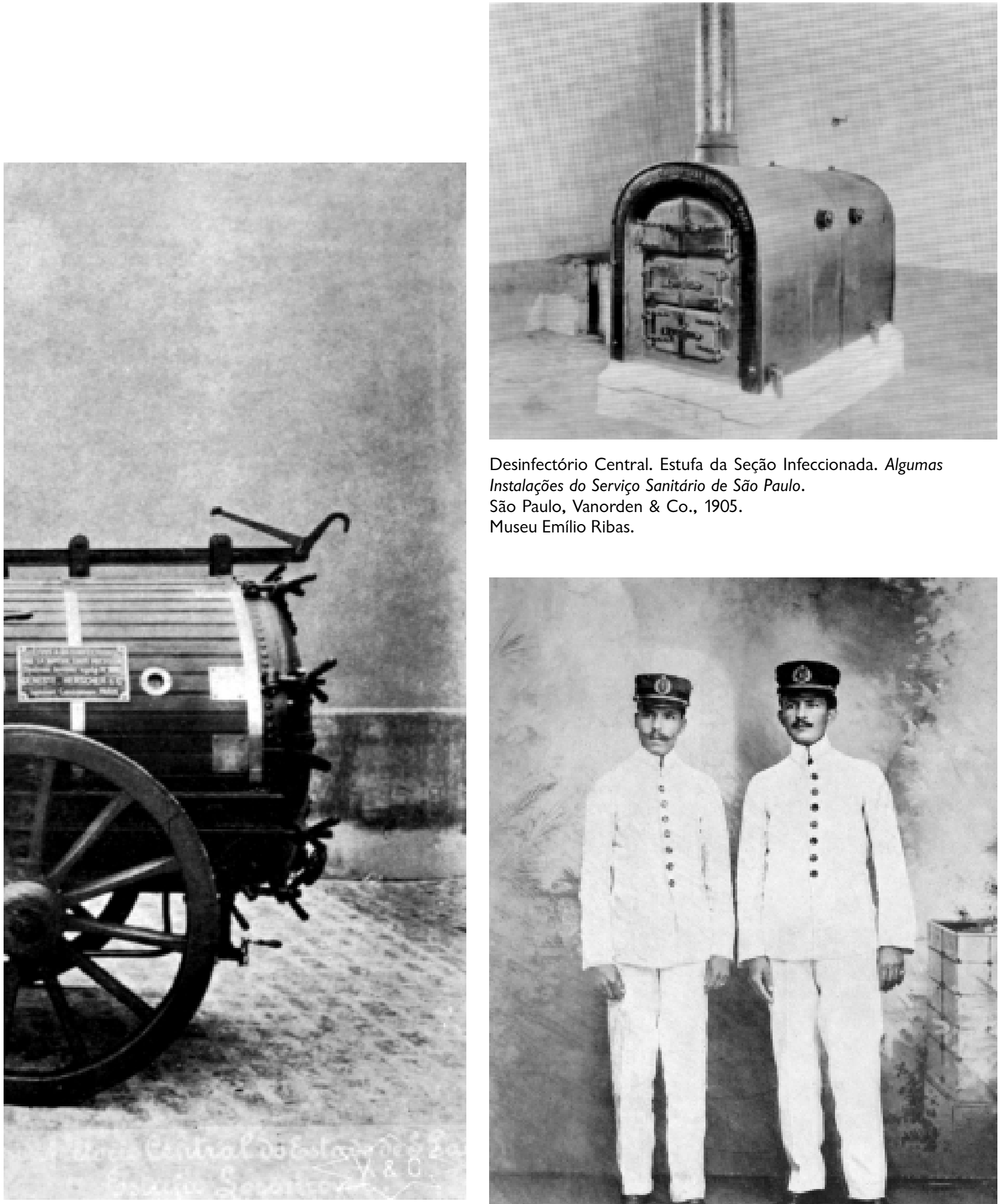

Desinfectório Central. Estufa da Seção Infeccionada. Algumas Instalações do Serviço Sanitário de São Paulo.

São Paulo, Vanorden \& Co., 1905.

Museu Emílio Ribas.

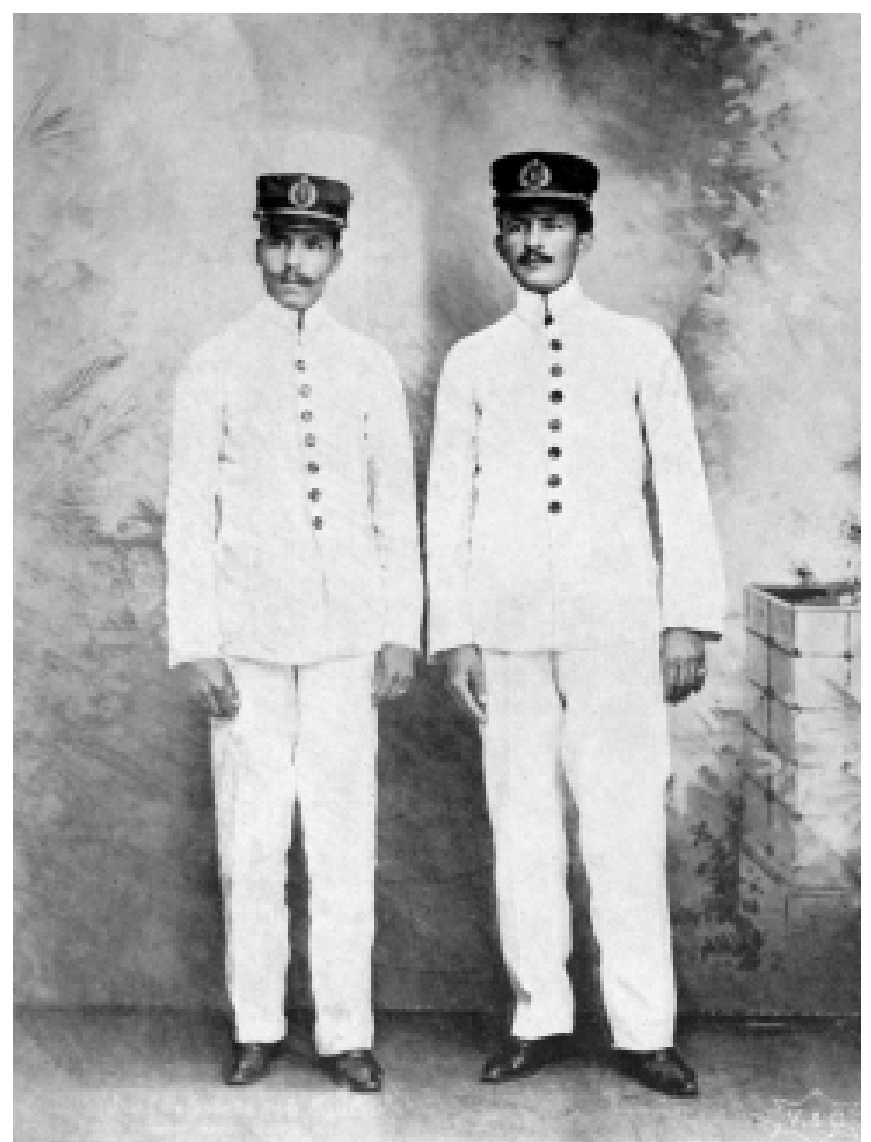

Funcionários do Desinfectório Central. Algumas Instalações do Serviço Sanitário de São Paulo. São Paulo, Vanorden \& Co., 1905. Museu Emílio Ribas. 


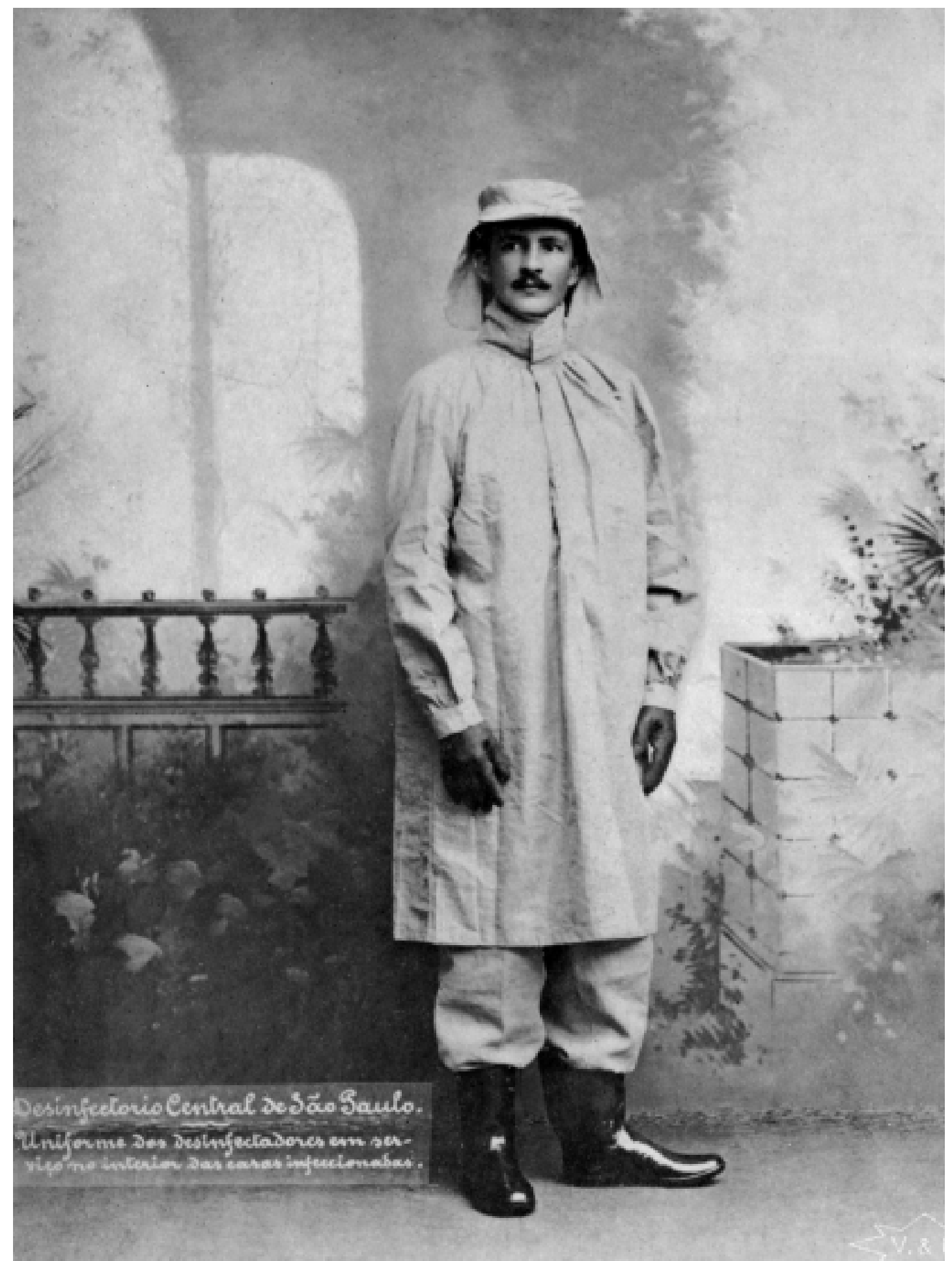

Desinfetador em serviço no interior de casa infeccionada. Algumas Instalações do Serviço Sanitário de São Paulo. São Paulo, Vanorden \& Co., 1905. Museu Emílio Ribas. 
Em Manguinhos

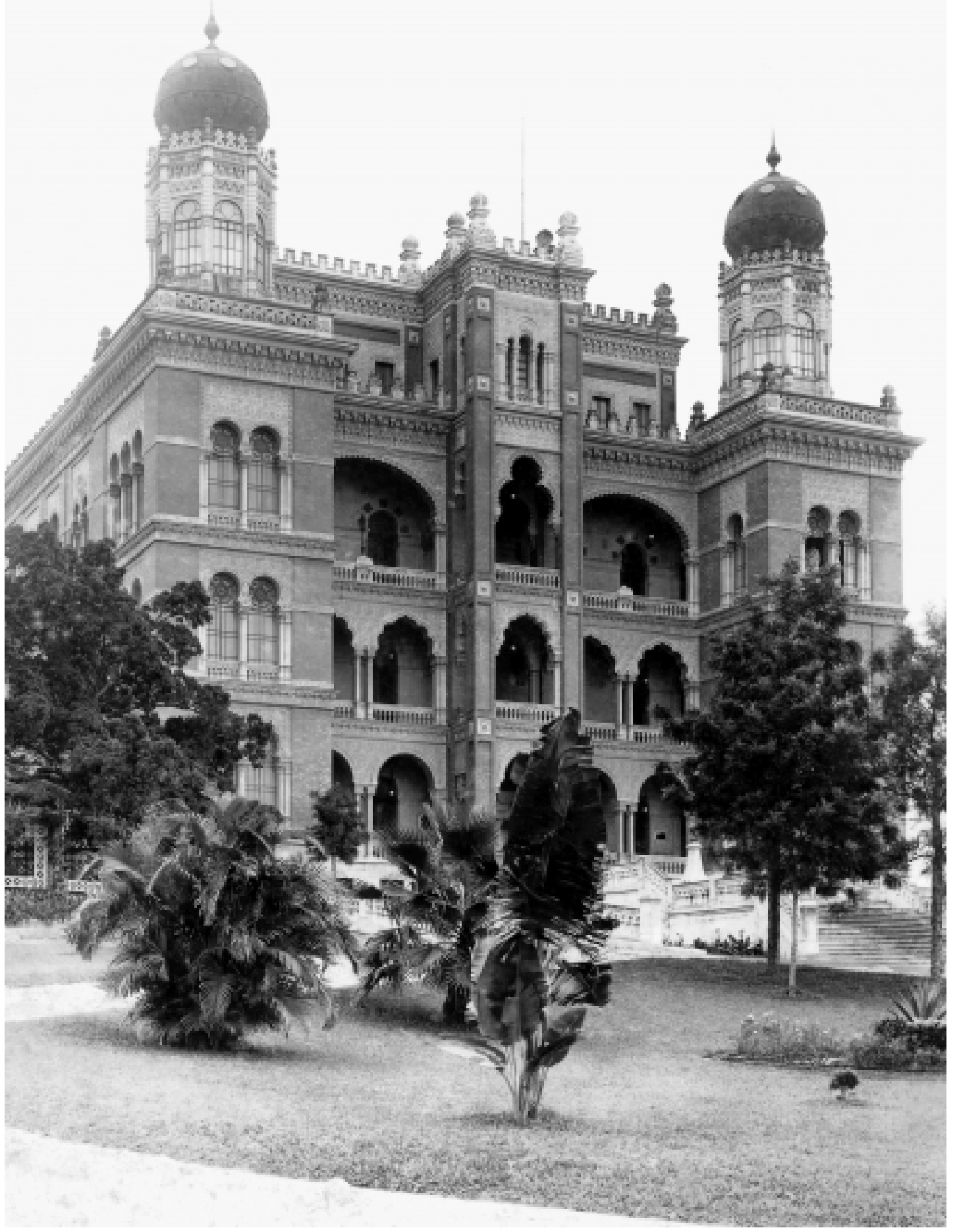

Pavilhão central do Instituto Oswaldo Cruz, em forma de Castelo mourisco, inaugurado em 1910. 


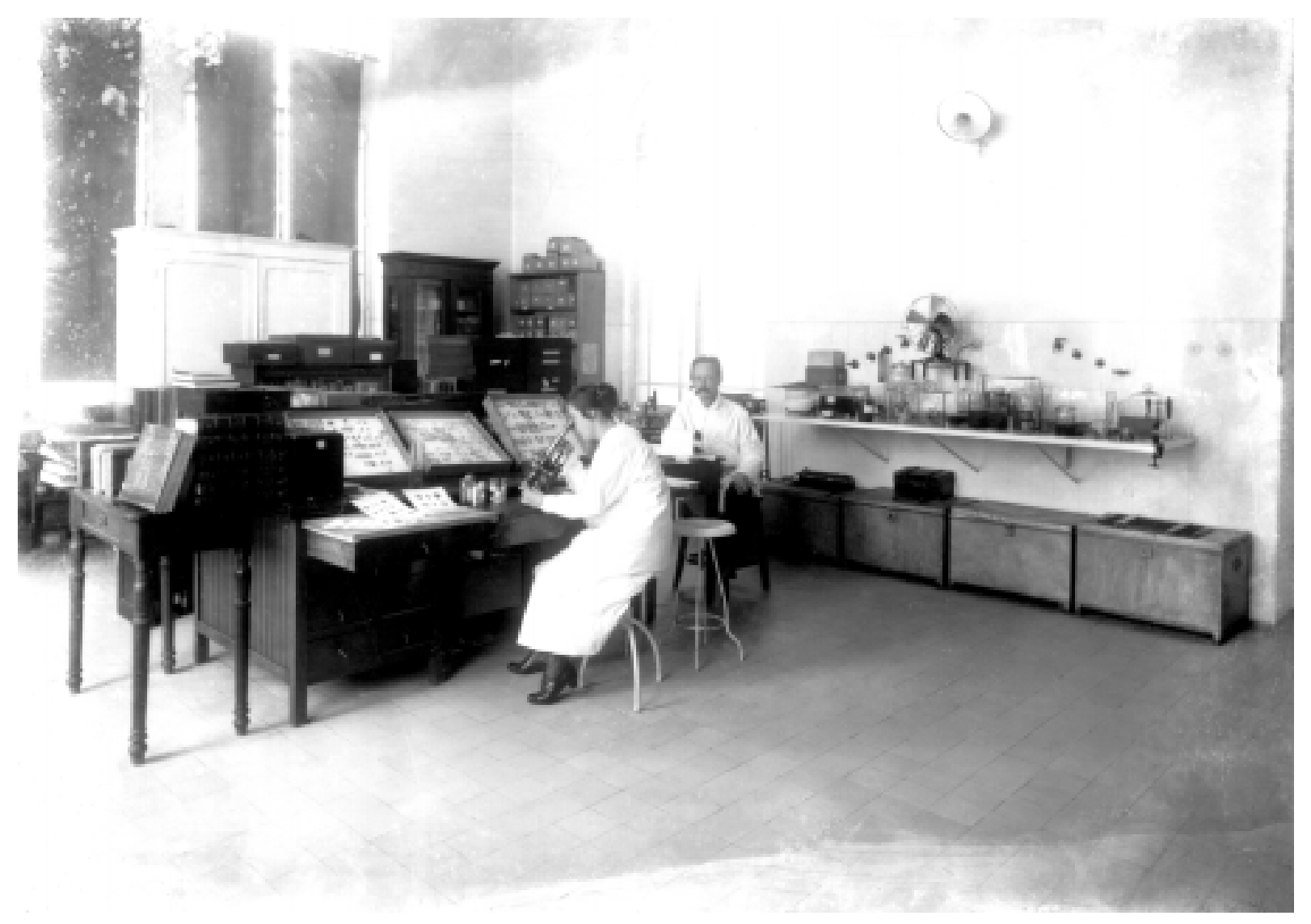

Adolpho Lutz e sua filha, Bertha, no laboratório de Manguinhos, s. d.

Casa de Oswaldo Cruz/Fiocruz, Departamento de Arquivo e Documentação, Setor Iconográfico, Acervo Adolpho Lutz.

A serviço da Inspetoria de Obras contra as Secas, Adolpho Lutz percorreu, junto com Astrogildo Machado, o vale do São Francisco, de Pirapora a Juazeiro, entre 17 de abril e 17 de julho de 1912. O período seco prejudicou a investigação do ecossistema da região e a coleta de espécies animais e vegetais. Em seu relatório, publicado nas Memórias do Instituto Oswaldo Cruz (1915. t. VII), os cientistas tentam explicar com argumentos raciais e socioeconômicos o atraso da região, e apresentam dados concernentes à incidência da doença de Chagas, febre amarela, alastrim, leishmaniose, febre tifóide, cólera, ancilostomíase, malária, entre outras.

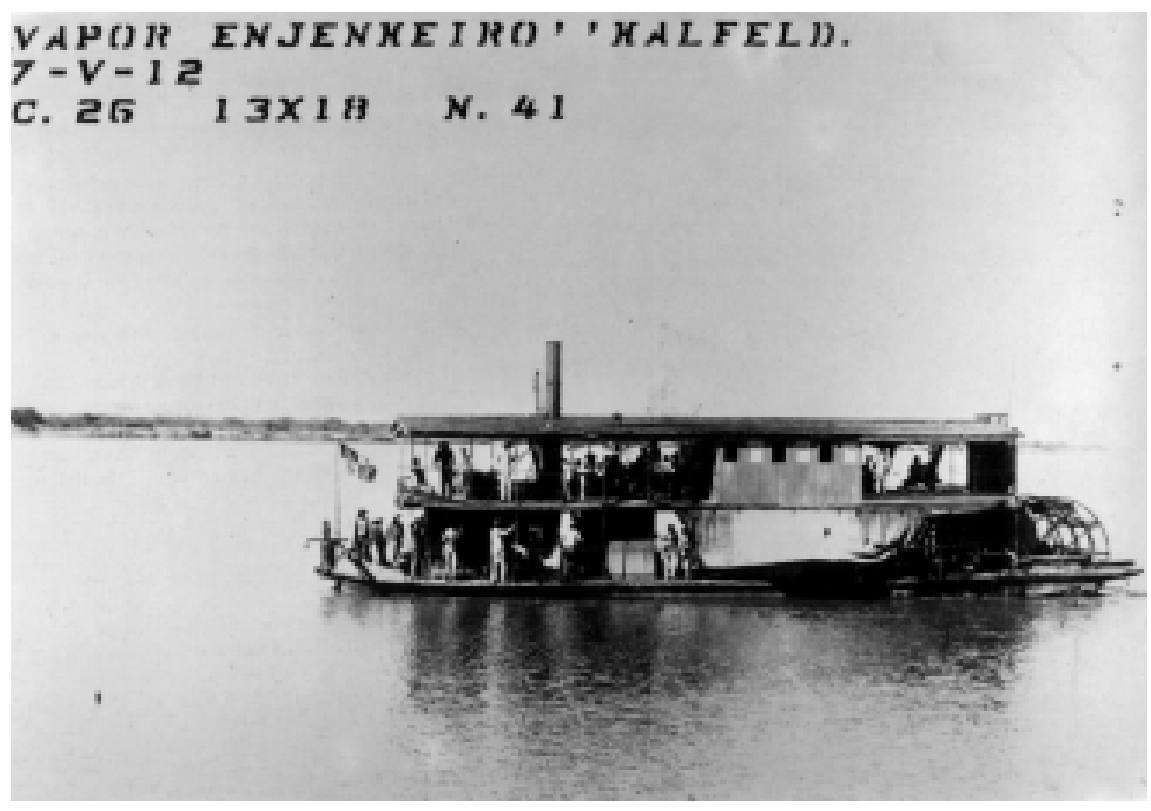




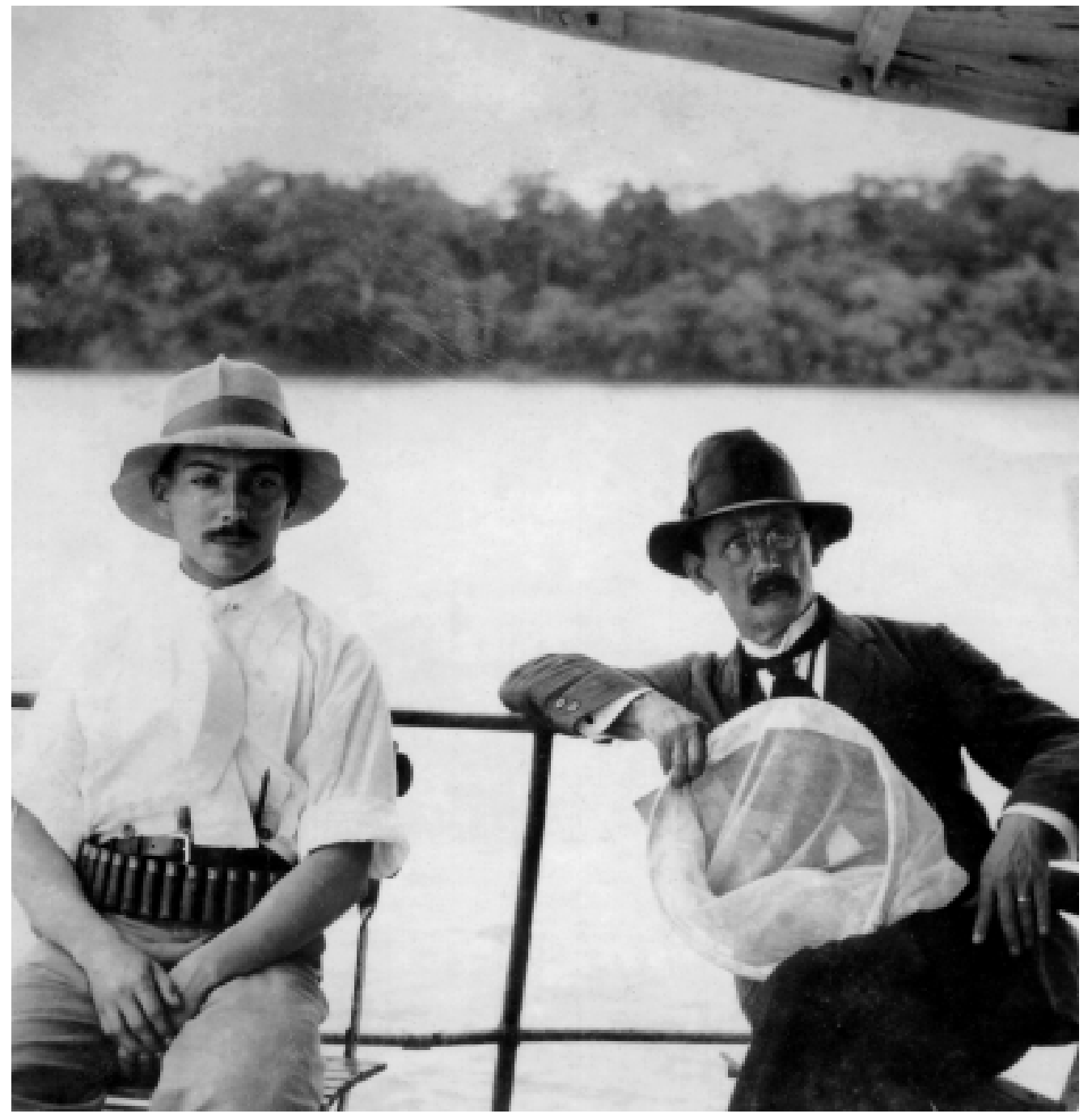

A bordo do España,

Adolpho Lutz desce o

rio Paraná, em 1918.

BRMN. Arquivo.

Fundo Bertha Lutz.

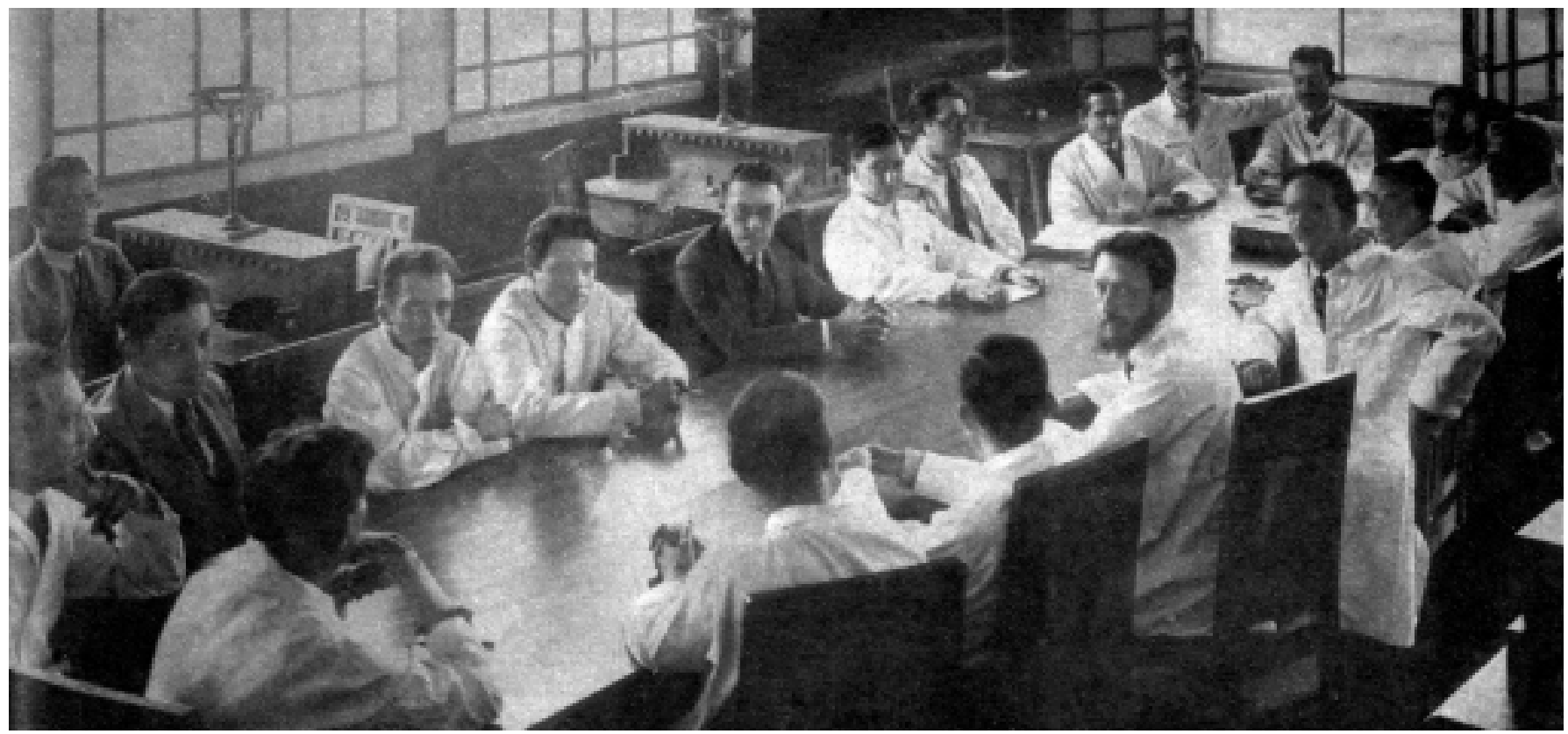

Lutz e outros cientistas numa das reuniões que a Sociedade de Biologia realizava na biblioteca localizada no Pavilhão central do Instituto Oswaldo Cruz.

BRMN. Arquivo. Fundo Adolpho Lutz. (Revista O mundo ilustrado, no 50, Rio de Janeiro, 9 de janeiro de 1956.) 


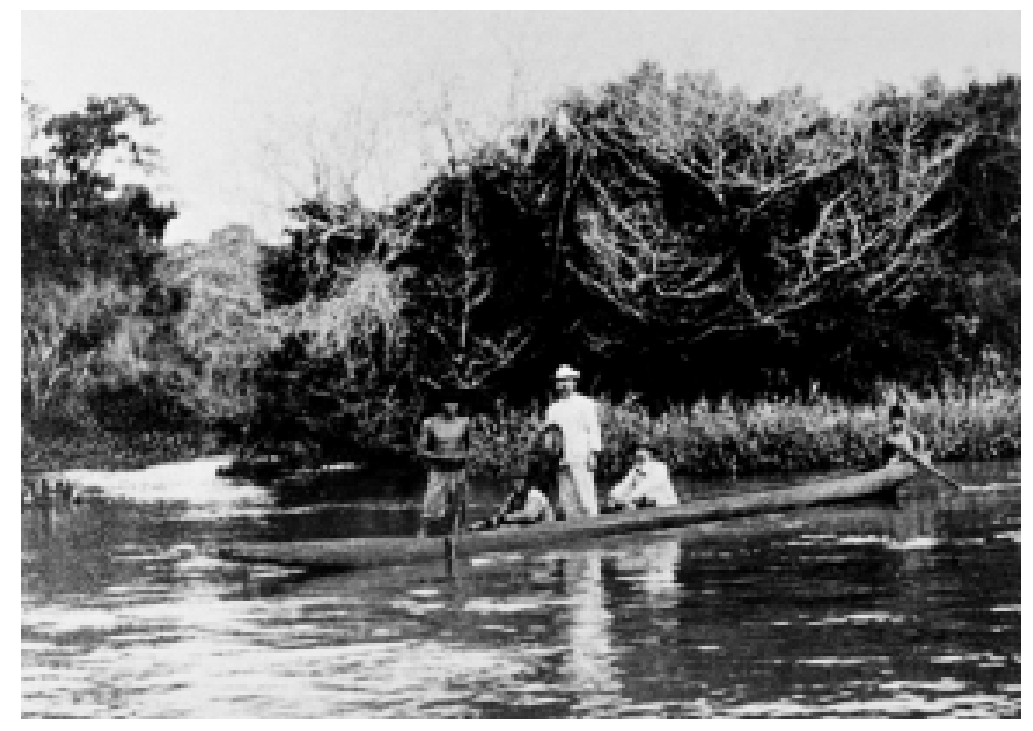

Lutz com Heráclides-César de Souza Araújo em Barra do Piqueri, rio Paraná, em 1918. Acervo do Instituto Adolfo Lutz.
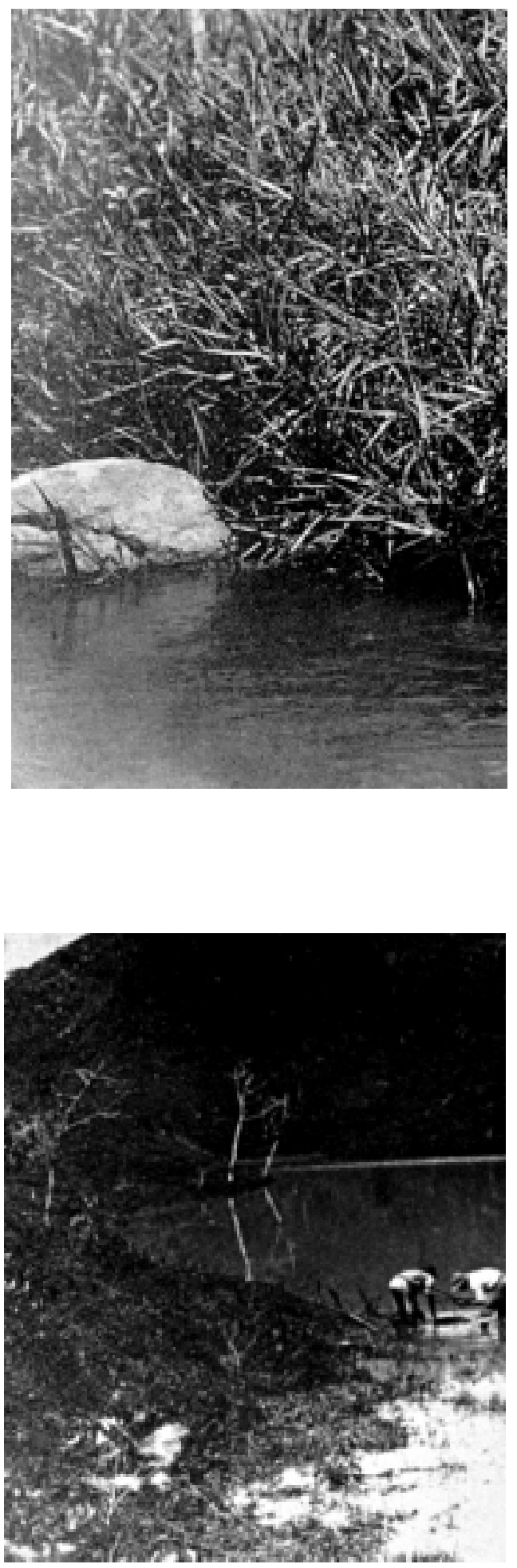

Sentado, Adolpho Lutz tem, à sua esquerda, Heráclides-César de Souza Araújo e Olympio da Fonseca, e à sua direita, Luis E. Migone. Fotografia tirada em San Bernardino, Paraguai, em 1918. Acervo do Instituto Adolfo Lutz. 


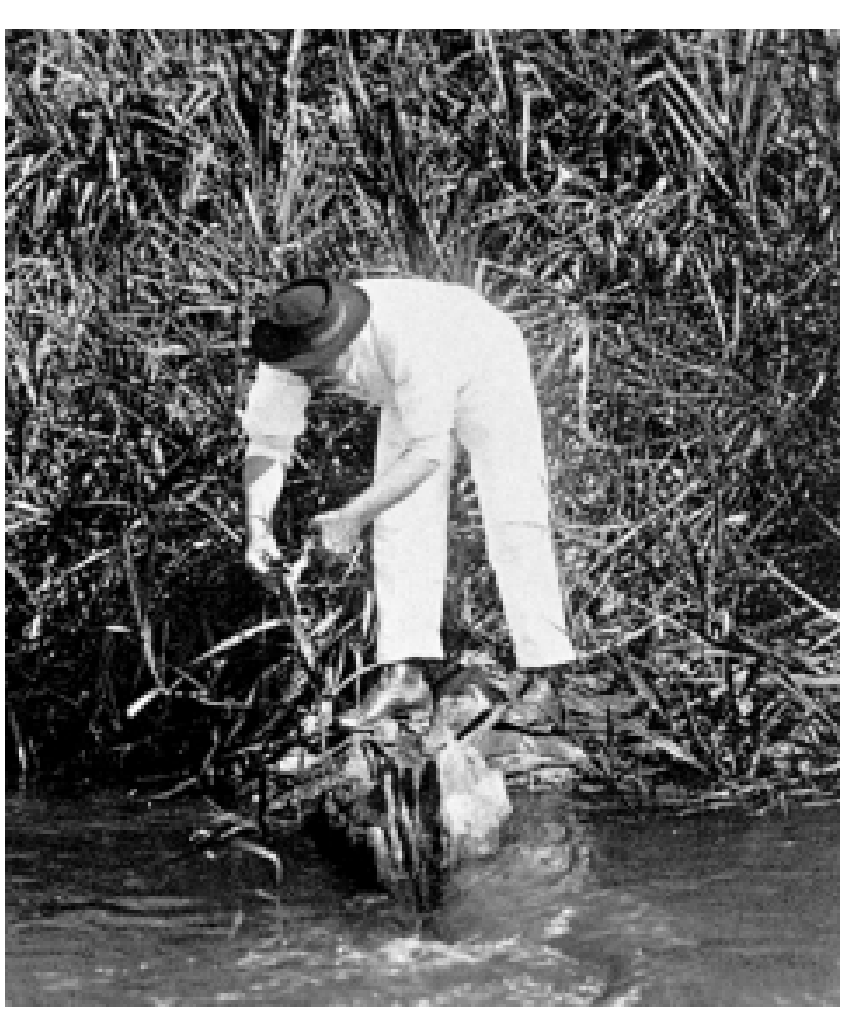

Lutz coleta material para estudos sobre anfíbios, à margem do rio Paraíba, em Resende (RJ). Acervo do Instituto Adolfo Lutz.

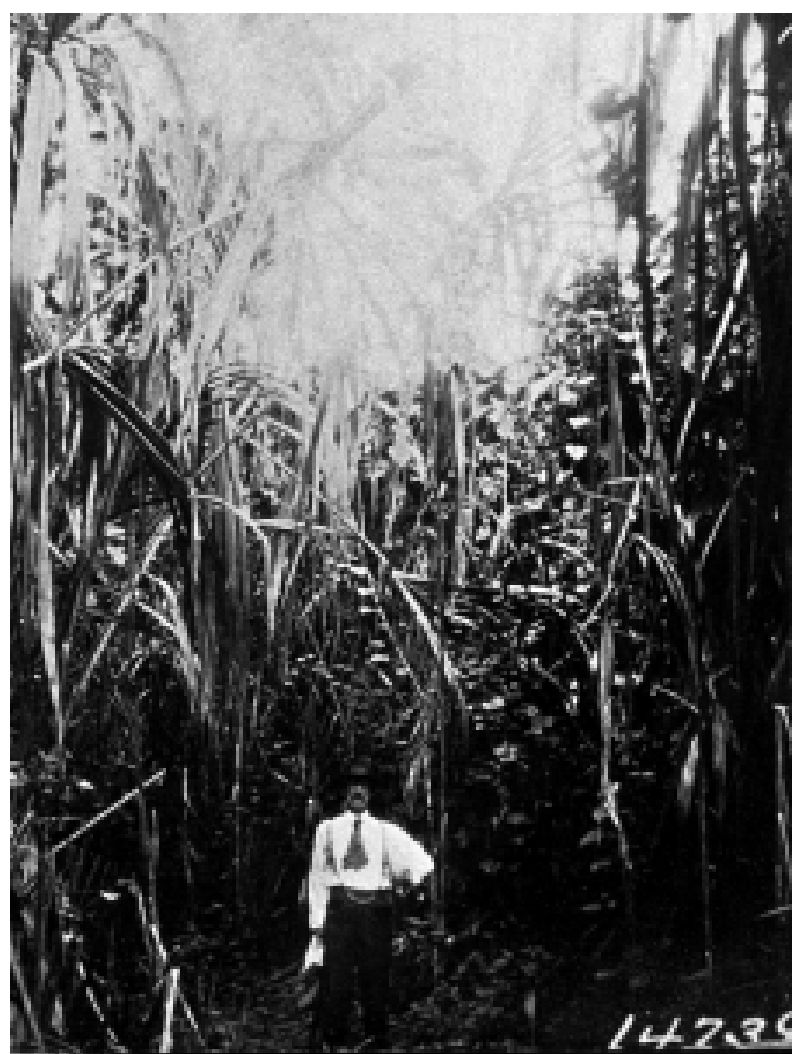

Lutz em Cana Brava, localidade próxima a Maracay, na Venezuela, em 1925. Acervo do Instituto Adolfo Lutz.

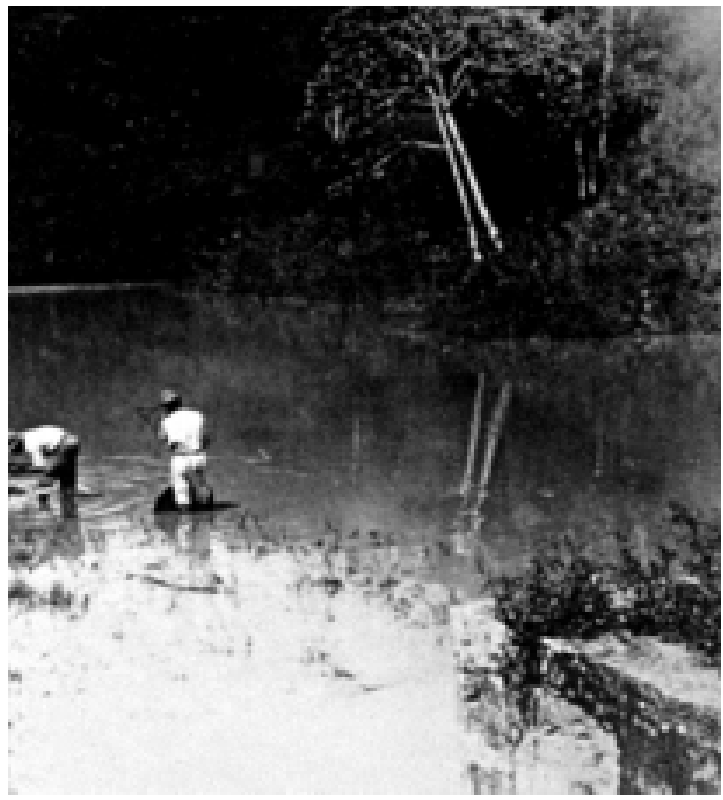

Adolpho Lutz coleta caramujos na Fazenda da Floresta, em Entre Rios, atual Três Rios (RJ). Acervo do Instituto Adolfo Lutz.

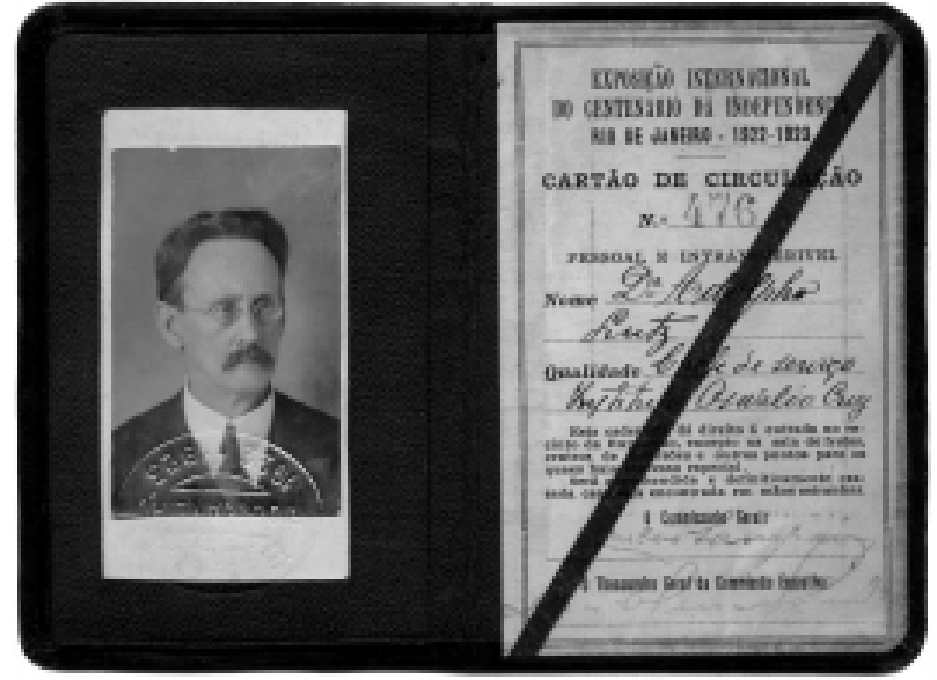

Documento usado por Adolpho Lutz, como chefe de Serviço do Instituto Oswaldo Cruz, para circular na exposição internacional comemorativa do centenário da independência do Brasil, em 1922. BRMN. Arquivo. Fundo Bertha Lutz. 
Adolpho Lutz com Carlos Chagas e Albert Einstein durante a visita deste ao Instituto Oswaldo Cruz, em maio de 1925. BRMN. Arquivo. Fundo Adolpho Lutz.

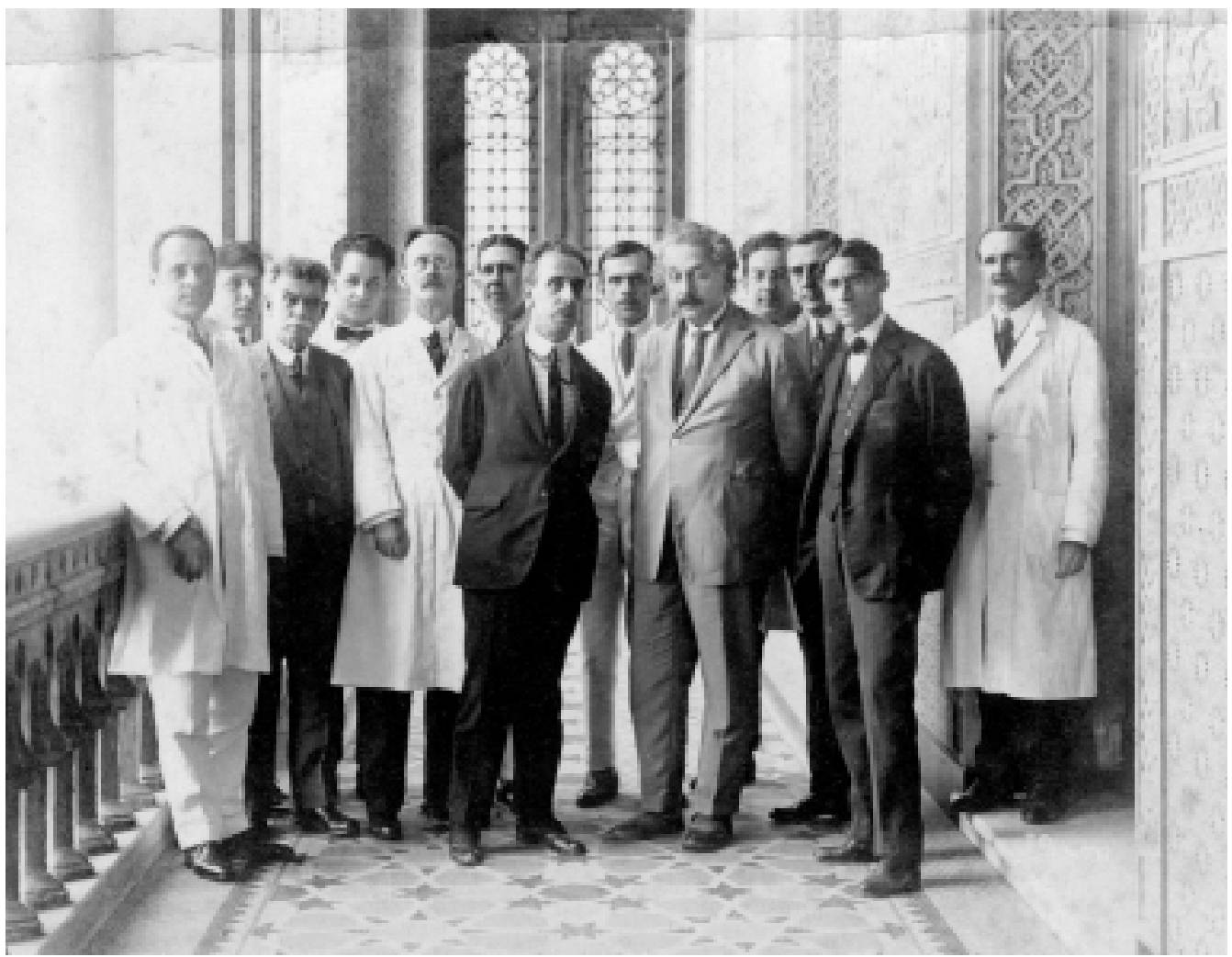

Adolpho e Bertha Lutz em

Washington, em 1925. Na fila da frente, da esquerda para a direita: $\mathrm{R}$. Kellog, Bertha Lutz, embaixador Gurgel do Amaral,

Adolpho Lutz e um personagem

identificado no verso da foto como "secretário", provavelmente da Embaixada do Brasil. Atrás, da esquerda para a direita, Miss Heloise Brainard e o dr. Leo S. Rose, diretor da União PanAmericana.

Foto cedida por Charlotte Emmerich.

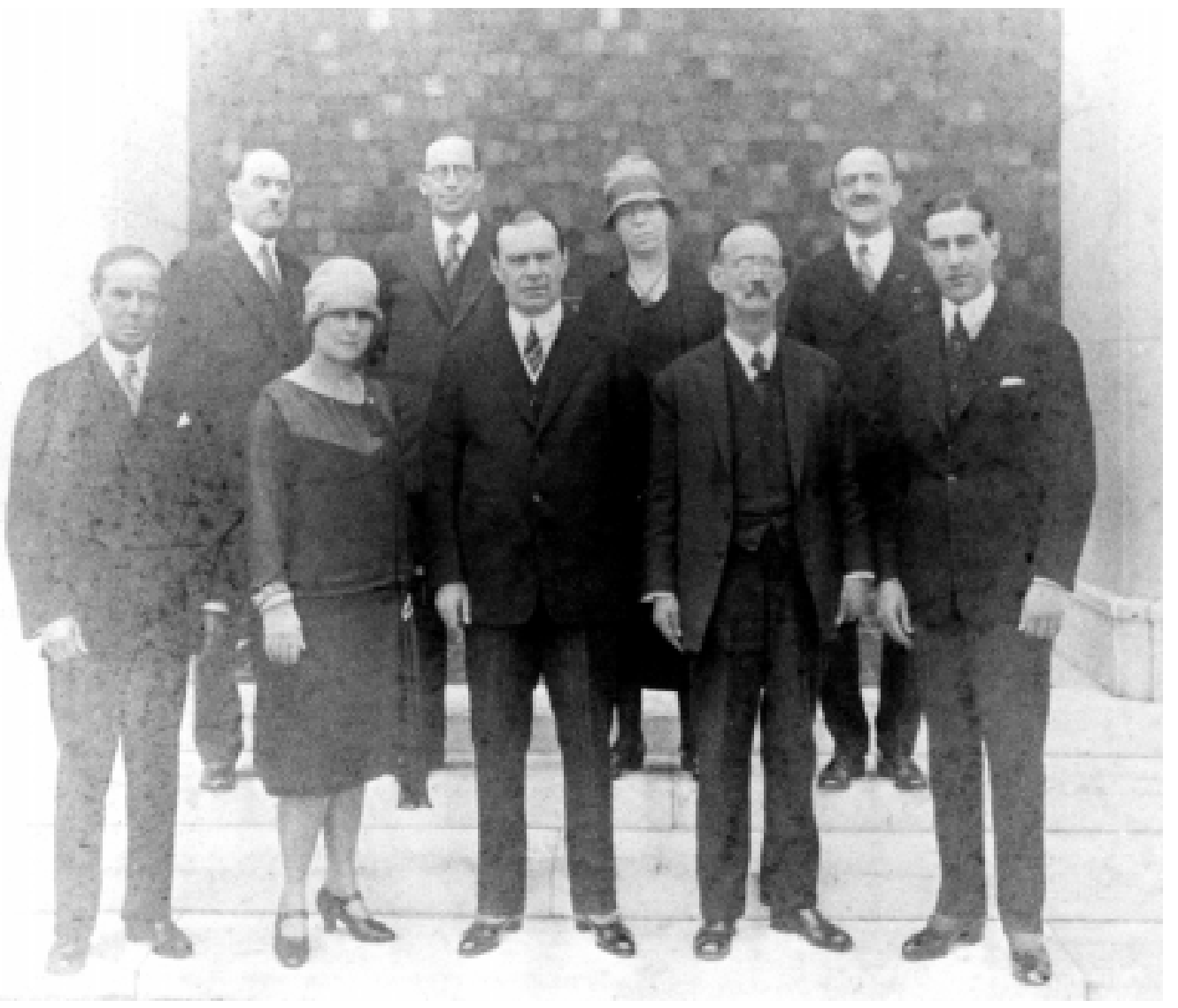




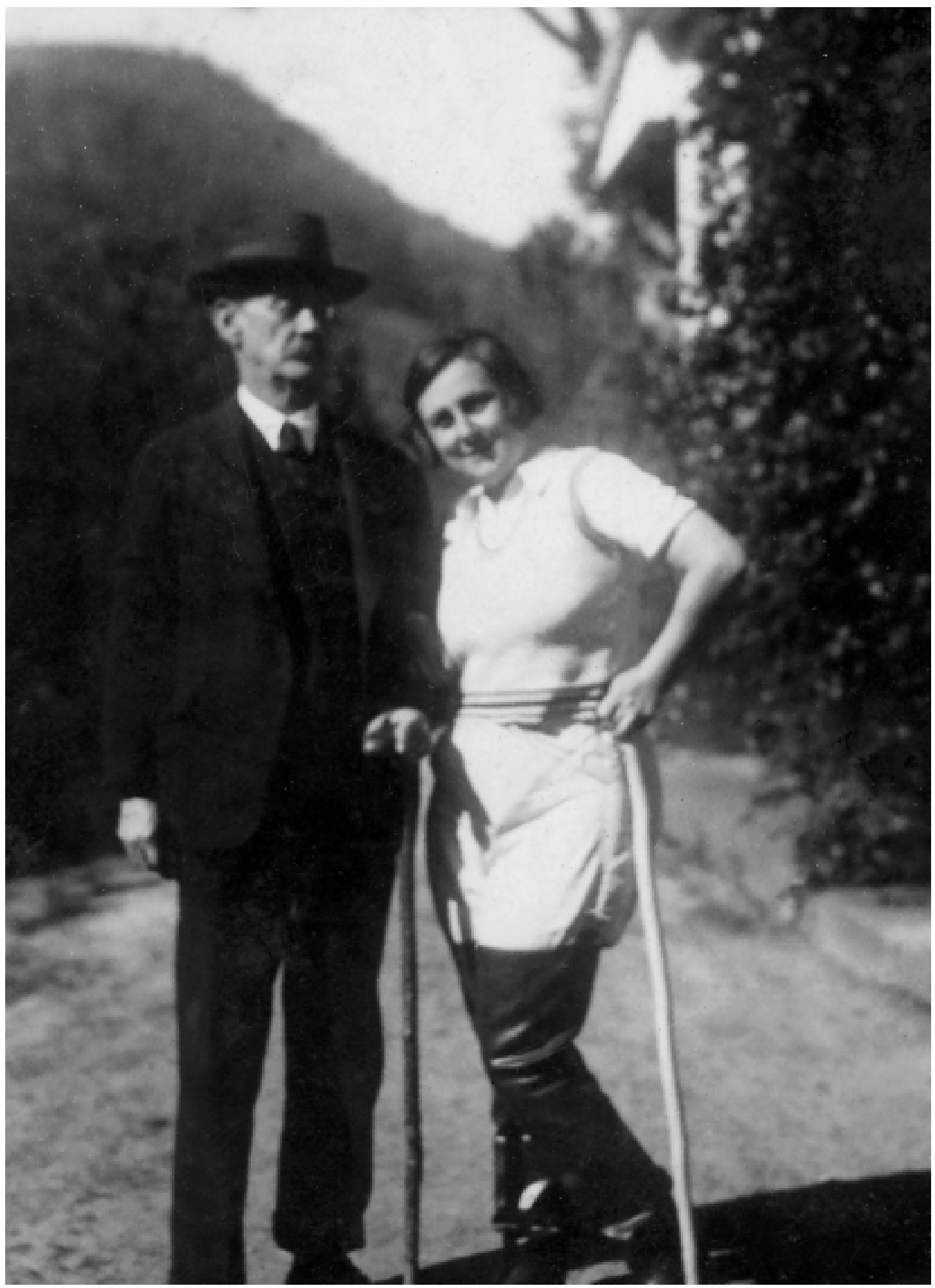

Adolpho e Bertha Lutz realizam estudos de campo em Nova Friburgo (RJ), em 1935. BRMN. Arquivo. Fundo Adolpho Lutz. 
Visitante

observa insetos

coletados por

Adolpho Lutz,

no laboratório

deste em

Manguinhos, ca.

1937.

BRMN.

Arquivo. Fundo

Bertha Lutz.

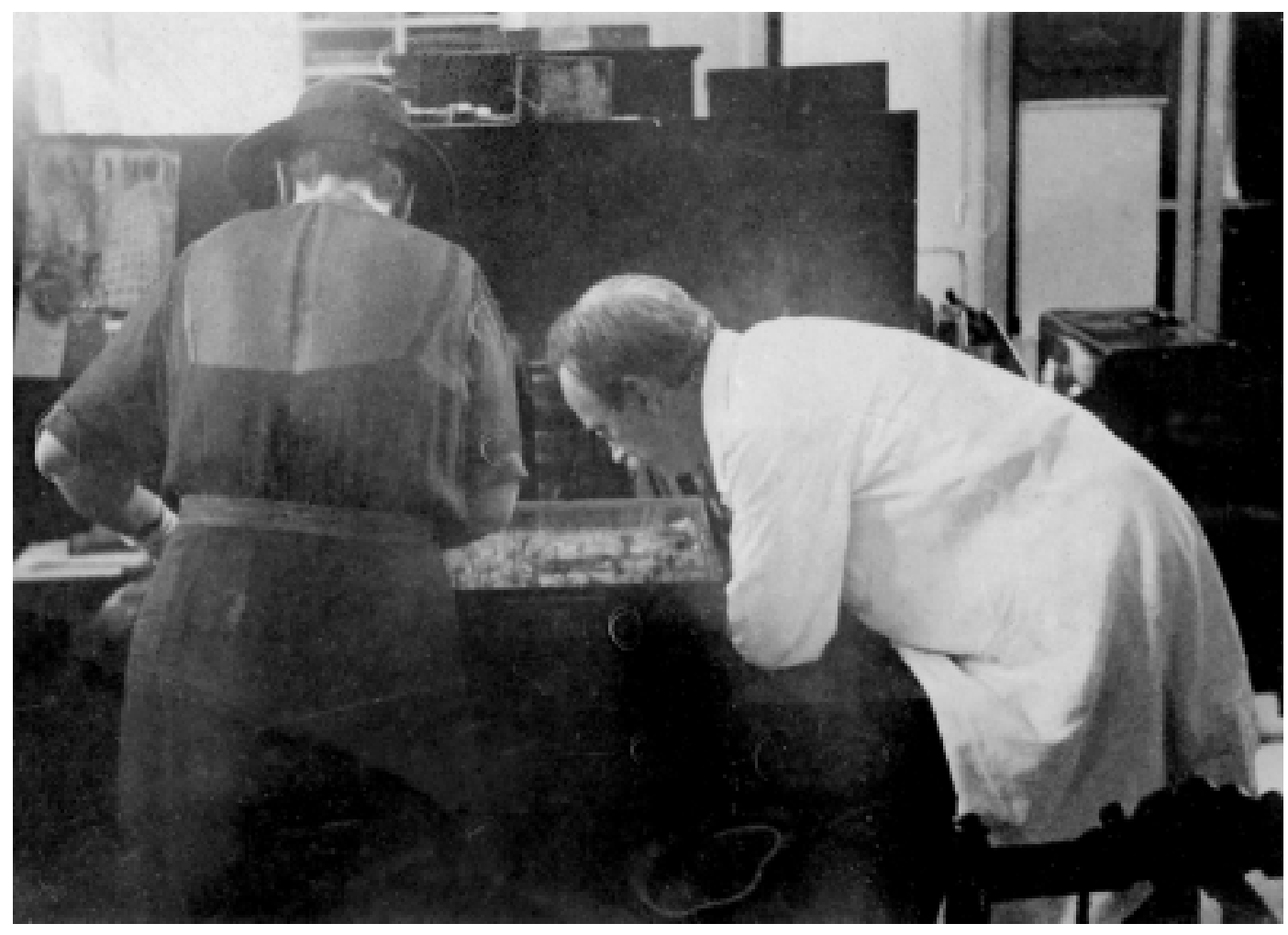

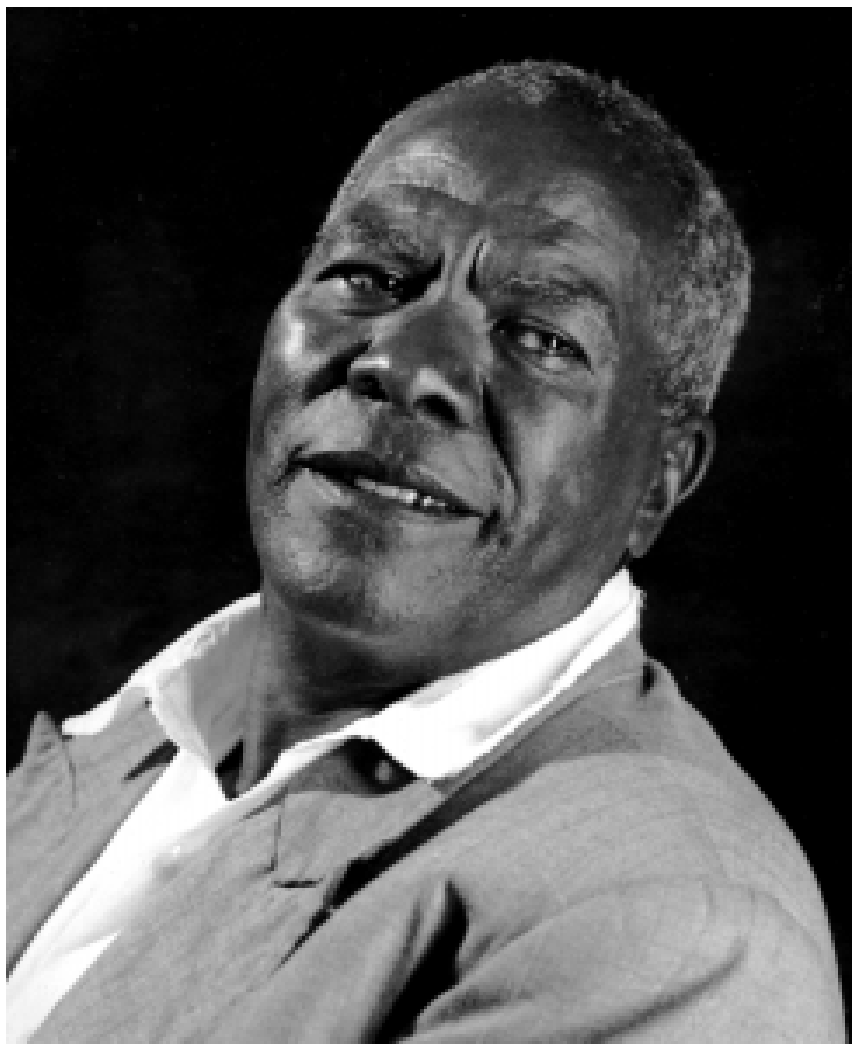

Joaquim Venâncio, o legendário auxiliar de Adolpho Lutz. BRMN. Arquivo. Fundo Adolpho Lutz.

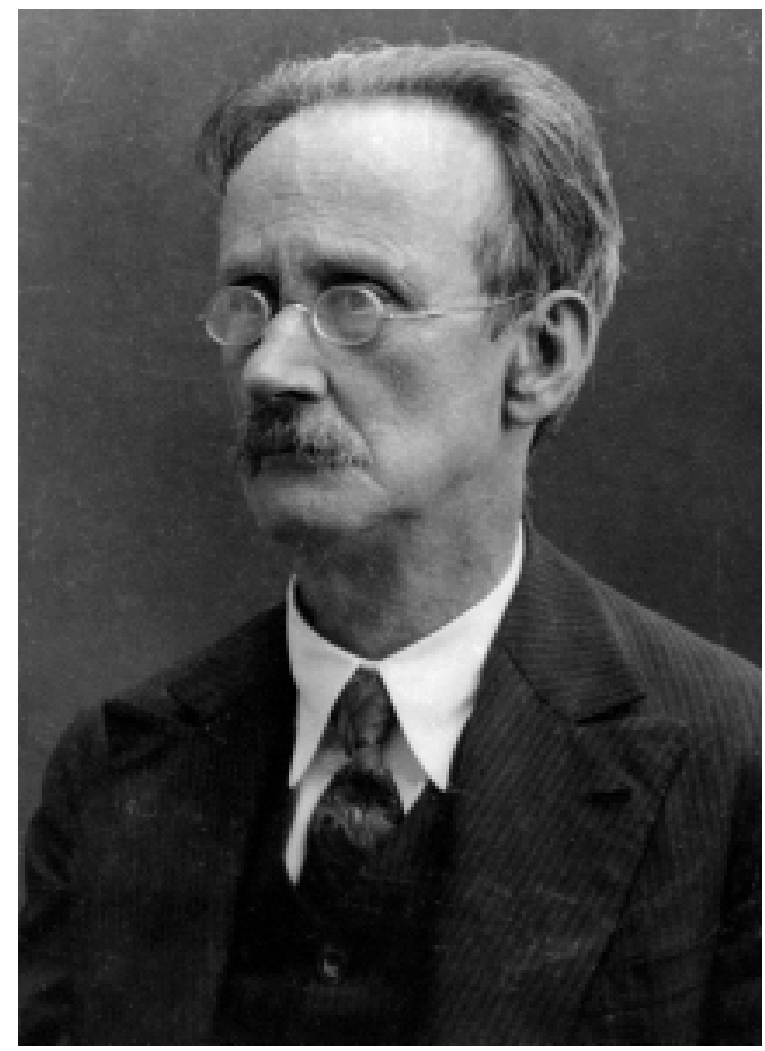

Adolpho Lutz, octogenário, no final dos anos 1930. BRMN. Arquivo. Fundo Adolpho Lutz. 


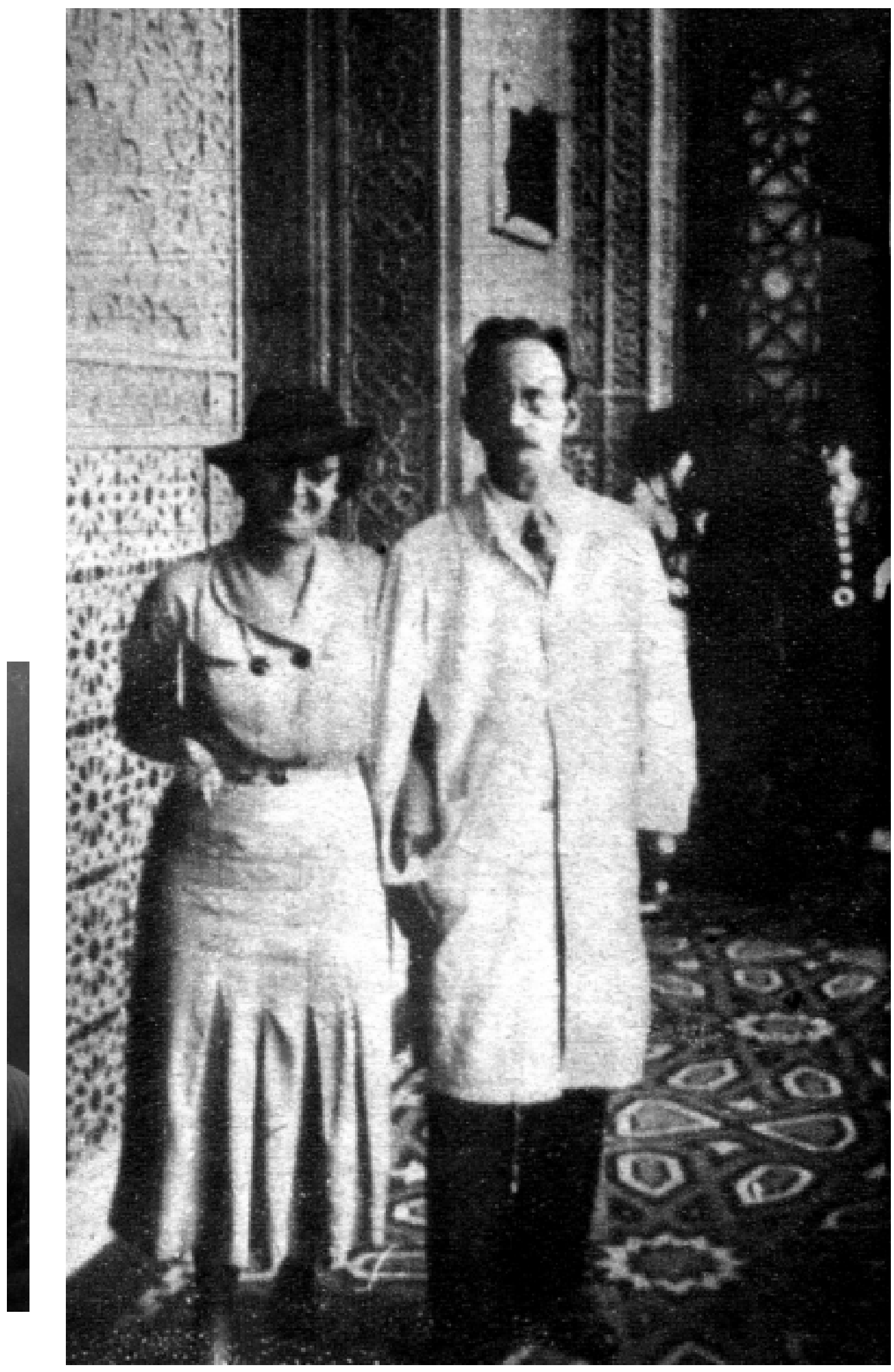

Adolpho Lutz e sua filha, Bertha, na varanda dianteira do primeiro pavimento do Castelo mourisco, vendo-se ao fundo a porta que dava acesso ao laboratório do cientista. Foto tirada em 1937. BRMN. Arquivo. Fundo Adolpho Lutz. (Revista O mundo ilustrado, no 50, Rio de Janeiro, 9 de janeiro de 1956.) 


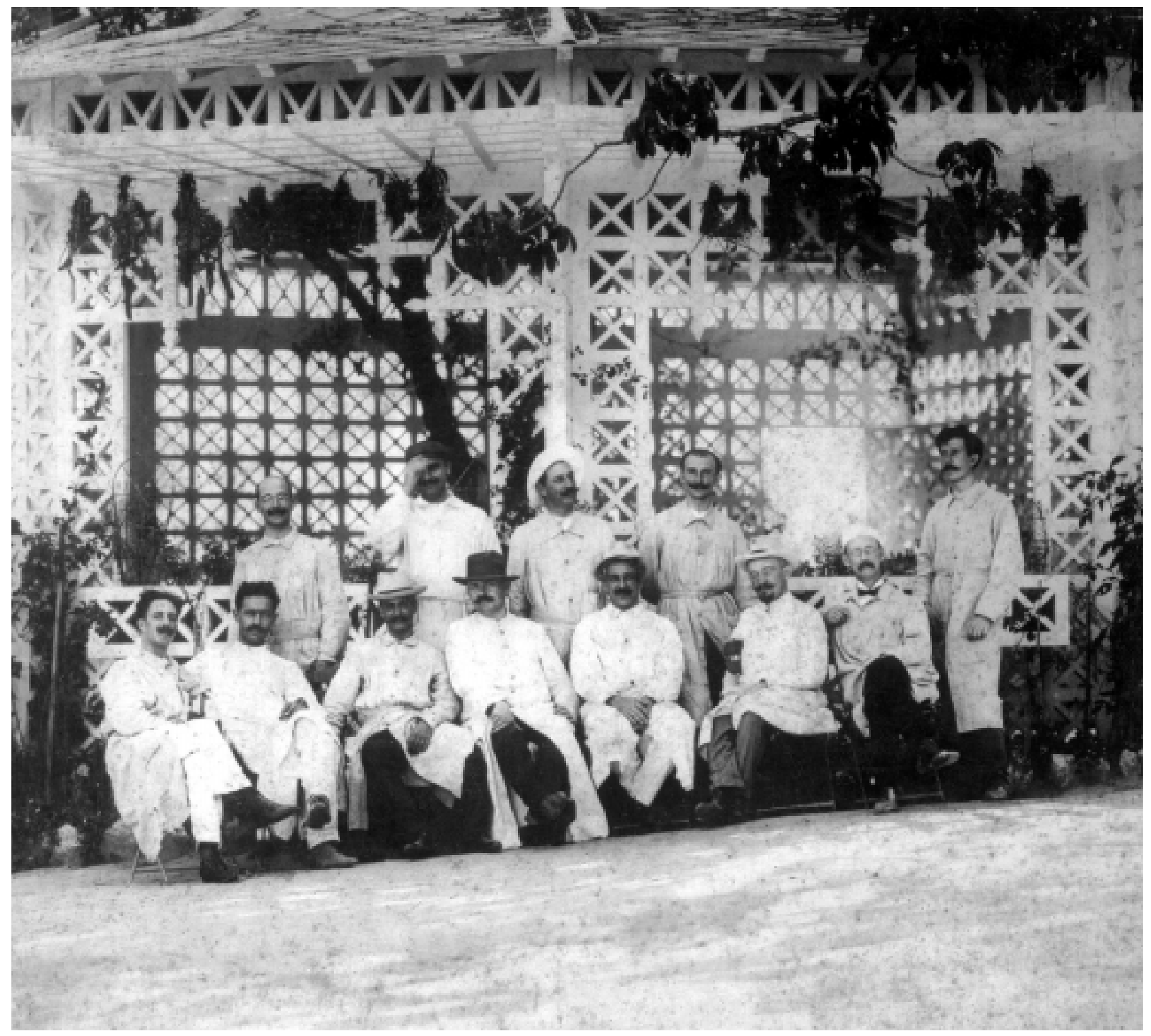

Cientistas de Manguinhos em 1908, em frente à Casa de Chá, em Manguinhos. Sentados, da esquerda para a direita: Carlos Chagas, José Gomes de Faria, Antônio Cardoso Fontes, Gustav Giemsa, Oswaldo Cruz, Stanislas von Prowazek e Adolpho Lutz. Em pé, Arthur Neiva, Henrique da Rocha Lima, Henrique de Figueiredo Vasconcellos, Henrique Aragão e Alcides Godoy. Foto de J. Pinto. Casa de Oswaldo Cruz/Fiocruz, Departamento de Arquivo e Documentação, Setor Iconográfico, Acervo Adolpho Lutz. 


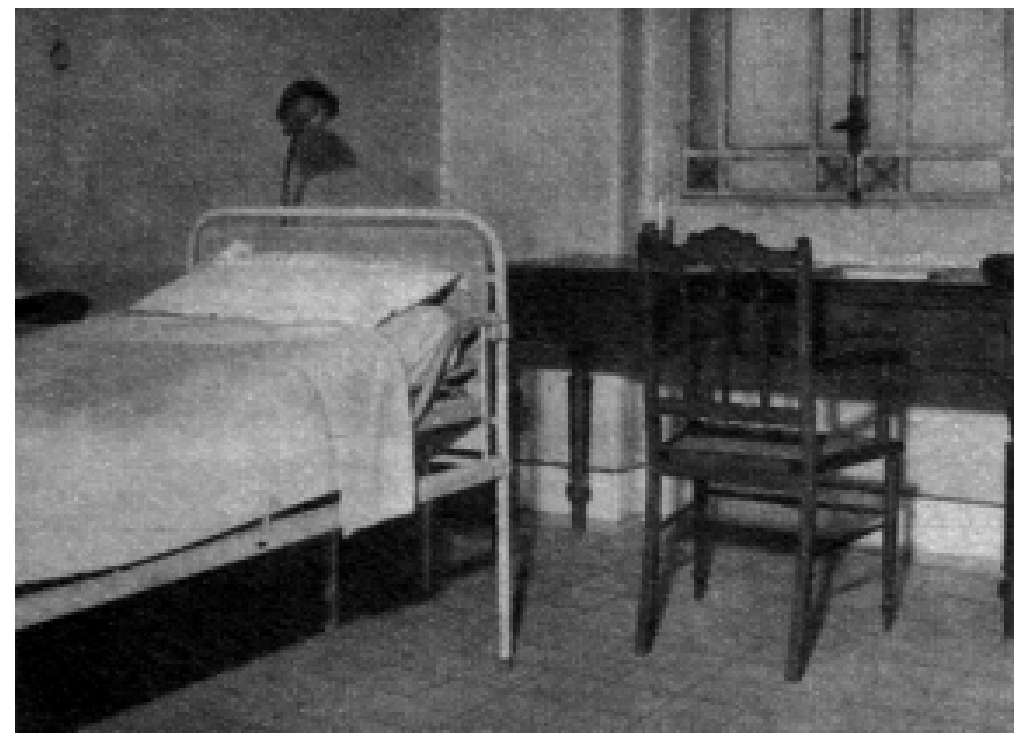

Quarto que Adolpho Lutz ocupava no pavilhão central de Manguinhos, sempre que os trabalhos de laboratório prolongavam-se noite adentro. Aí residiu quando esteve afastado da família, durante a Primeira Guerra Mundial.

BRMN. Arquivo. Fundo

Adolpho Lutz. (Revista

O mundo ilustrado, $\mathrm{n}^{-}$50,

Rio de Janeiro, 9 de janeiro de 1956.)

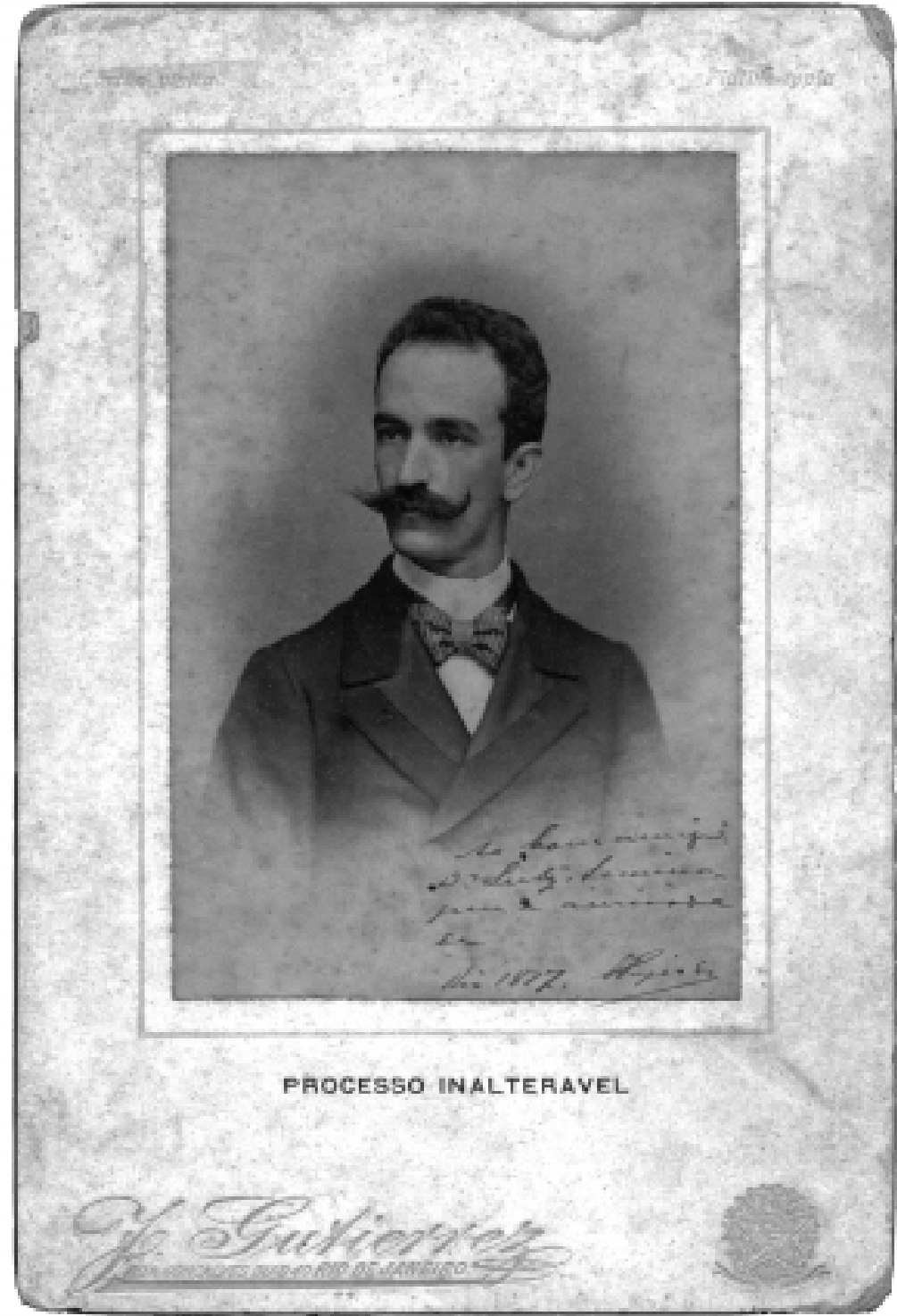

"Recordo-me bem de que o retrato de Fajardo era um dos poucos que se encontravam no quarto de Manguinhos onde morava Lutz, como

reconhecimento ao concurso prestado pelo seu desinteressado amigo" (Arthur Neiva, Necrológico do professor Adolpho Lutz 1855-1940. Rio de Janeiro, Imprensa Nacional, 1941, p. viii). Leão de Aquino pinta este retrato de Fajardo: "Figura inconfundível de verdadeiro fidalgo à antiga, nada tinha de vulgar.

Naturalmente elegante, de estatura mediana, possuía bela fronte espaçosa, olhos muito vivos e expressivos, cabelos muito negros e usava longos bigodes à kaiser, como era de moda na época. Tinha a tez pálida, porém de aspecto sadio. As suas atitudes distintas, seu modo pausado de falar, simples e correto, inspiravam, logo à primeira vista, simpatia e respeito" (Revista Medica Municipal, jul.dez. 1945, pp. 167, 170-1). 


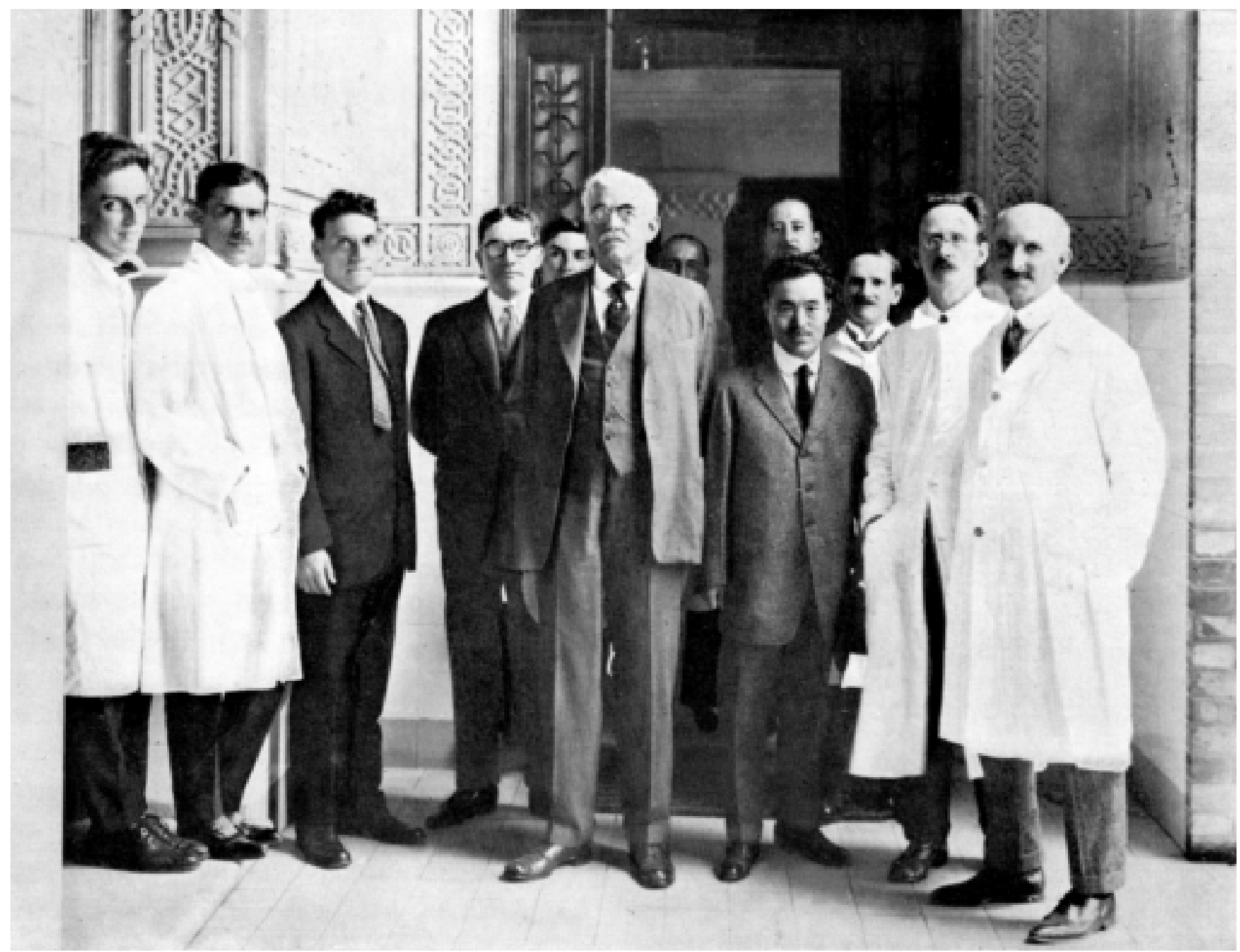

Visita de Hideyo Noguchi ao Instituto Oswaldo Cruz, em 1924. Da direita para a esquerda, Evandro Chagas, Astrogildo Machado, figura não identificada, Raul de Almeida Magalhães, Olympio da Fonseca Filho, Joseph H. White, Hideyo Noguchi, Leocádio Chaves, Adolpho Lutz e Henrique de Beaurepaire Aragão.

Durante o ano de 1919, Noguchi, da Fundação Rockefeller, publicou 12 artigos em que procurava demonstrar que a febre amarela era causada por um microrganismo da família das espiroquetáceas que classificou como Leptospira icteroide. Os pesquisadores de Manguinhos não conseguiam observar nada que confirmasse o que Noguchi havia descrito. O bacteriologista japonês desfrutava, porém, de tamanho prestígio, que todos pensavam que o insucesso fosse devido à inexperiência dos brasileiros. Uma exceção era Adolpho Lutz. Estudara já a biologia das Spirochetaceae e afirmava que, se a febre amarela tivesse por agente um microrganismo daquela família, ele o teria visto (Olympio da Fonseca Filho, A Escola de Manguinhos: contribuição para o estudo do desenvolvimento da medicina experimental no Brasil. Oswaldo Cruz, Monumenta Histórica. São Paulo, s.n., 1974, pp. 33-6). 


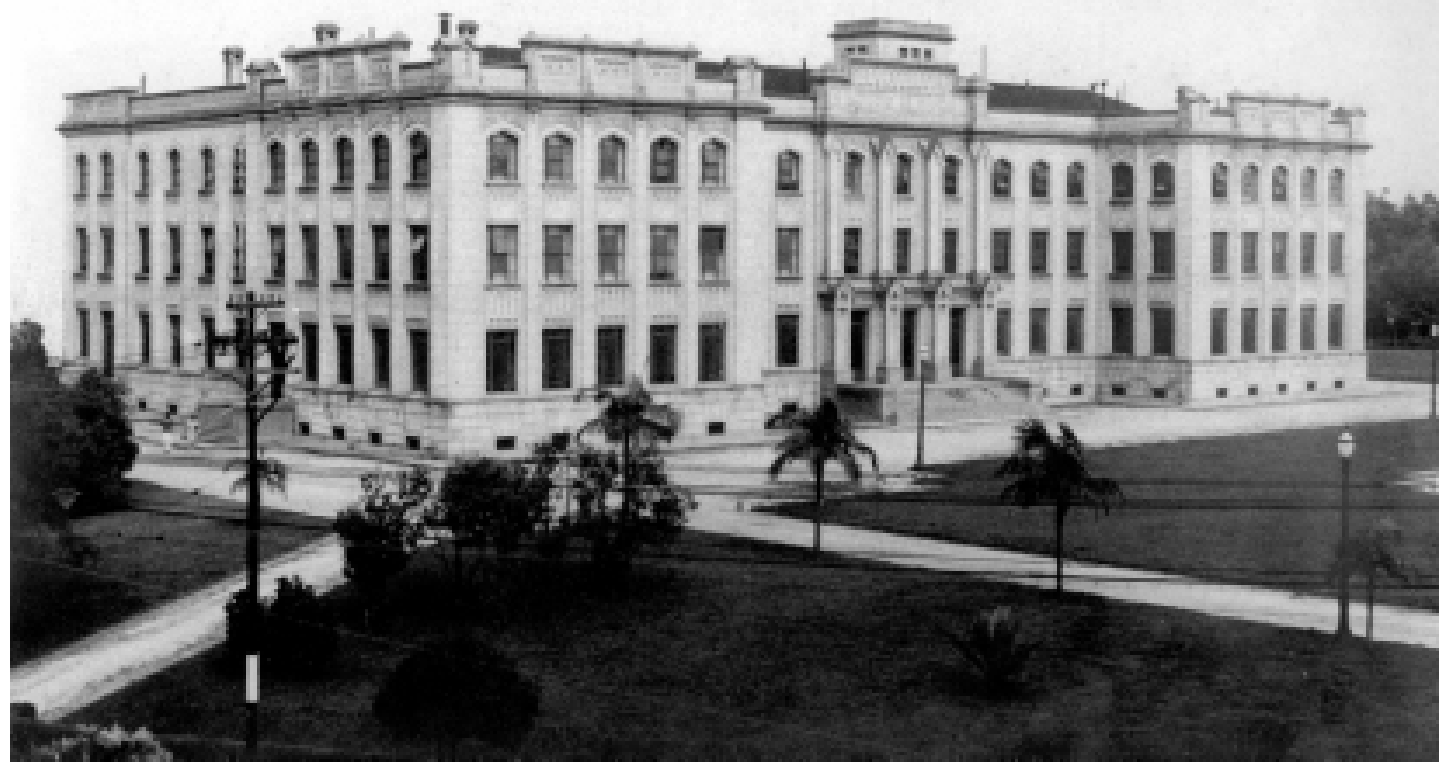

Foto do Instituto Adolpho Lutz da década de 1940, tirada pouco depois de sua inauguração. Museu Emílio Ribas.

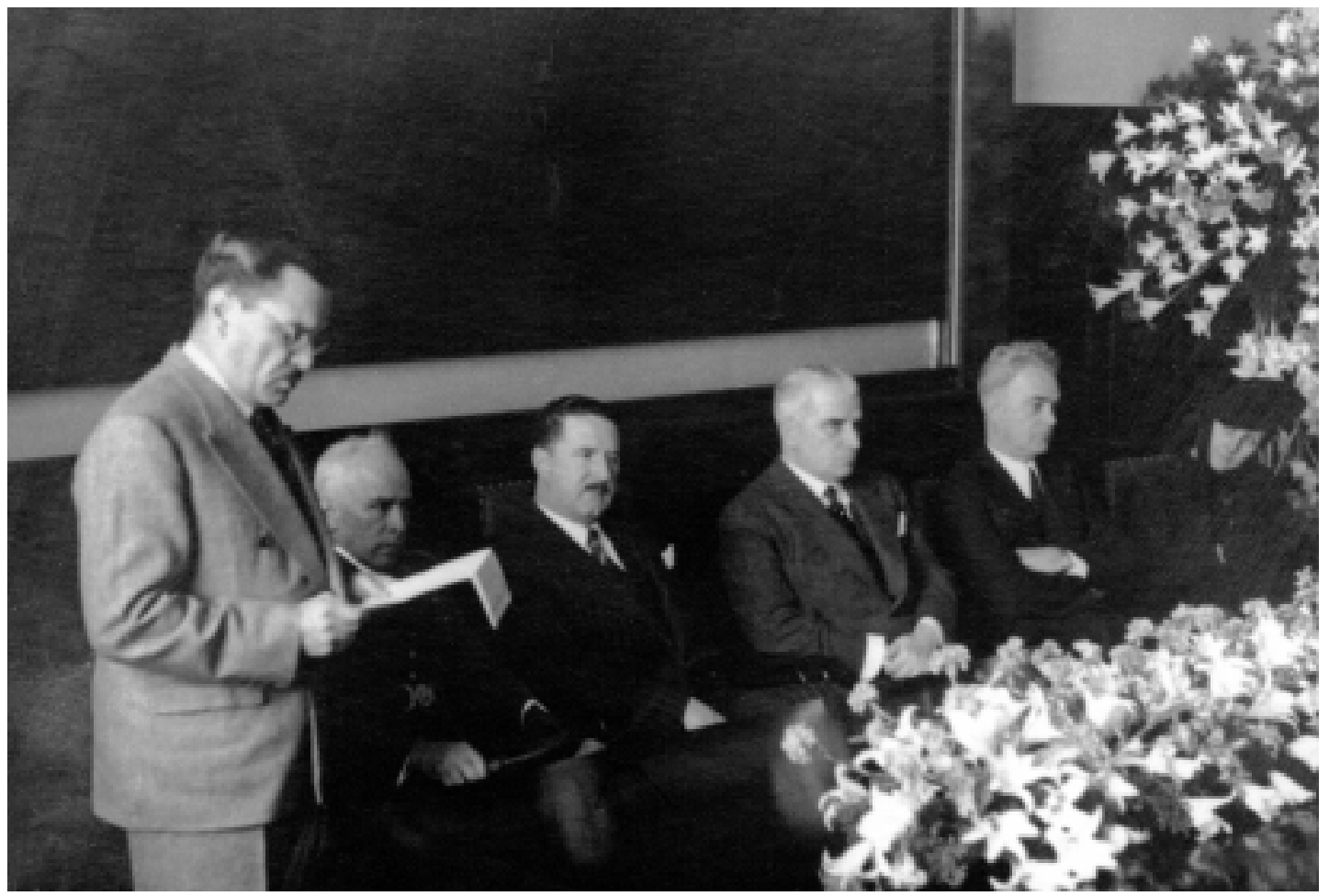

Mario Lins, secretário de Educação e Saúde Pública, discursa na inauguração do Instituto Adolpho Lutz, em 27 de outubro de 1940, logo em seguida à morte do cientista ( 6 de outubro). No centro da mesa, o governador Adhemar de Barros e, no canto, à direita, Bertha Lutz guardando luto. 


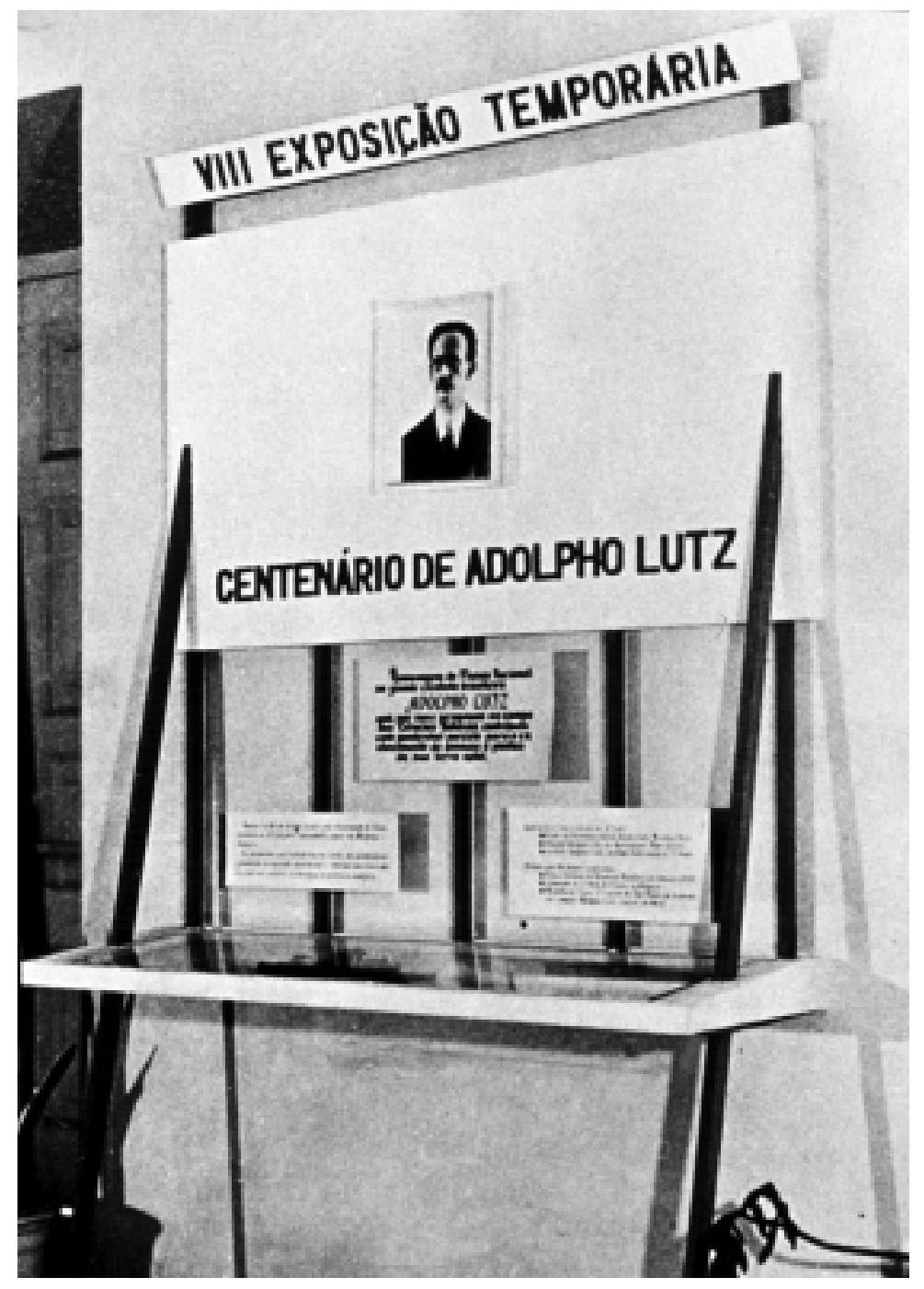

Peça de uma das exposições realizadas por ocasião do centenário de nascimento de Adolpho Lutz, em 1955. Acervo do Instituto Adolfo Lutz.

Busto de Adolpho Lutz esculpido para a comemoração do $25^{\circ}$ aniversário do Instituto Adolfo Lutz. BRMN. Arquivo.

Fundo Adolpho Lutz.

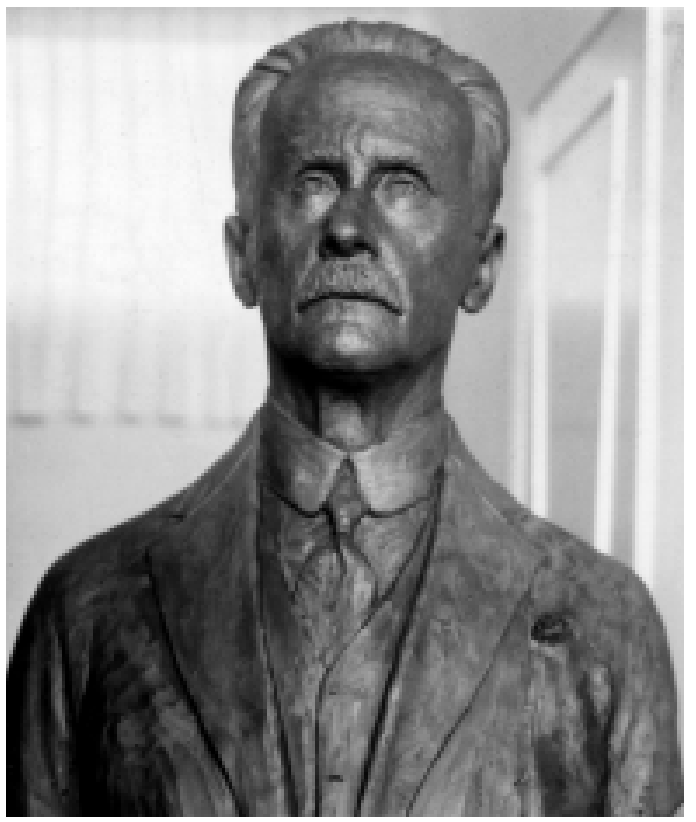

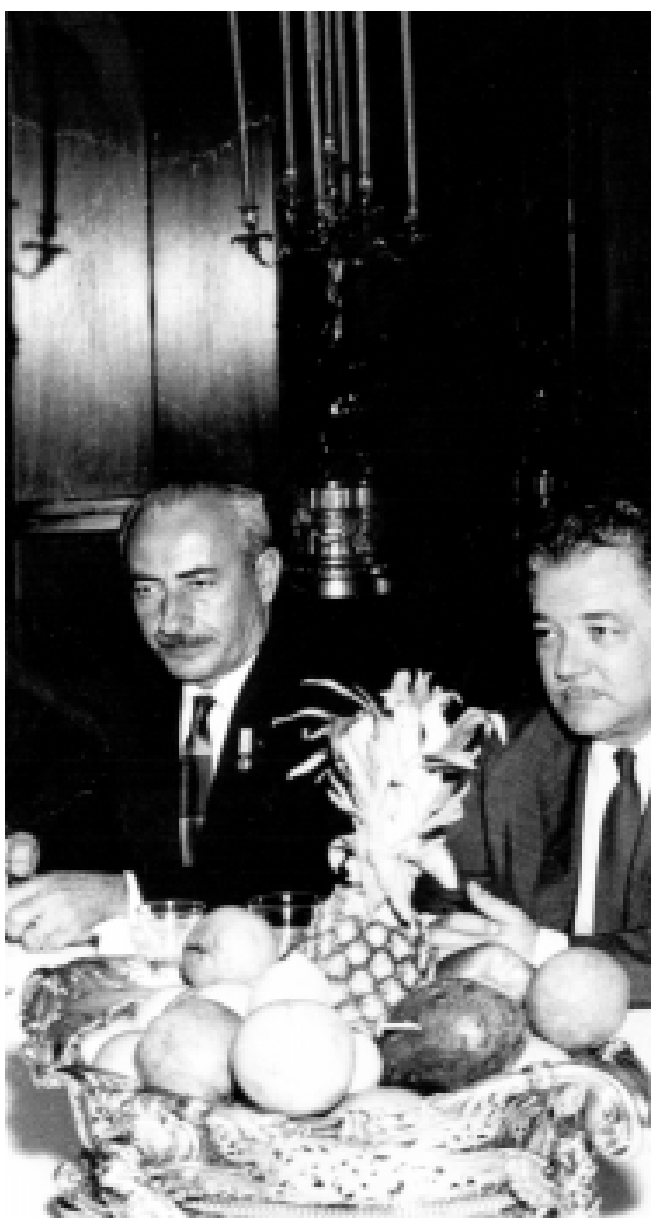

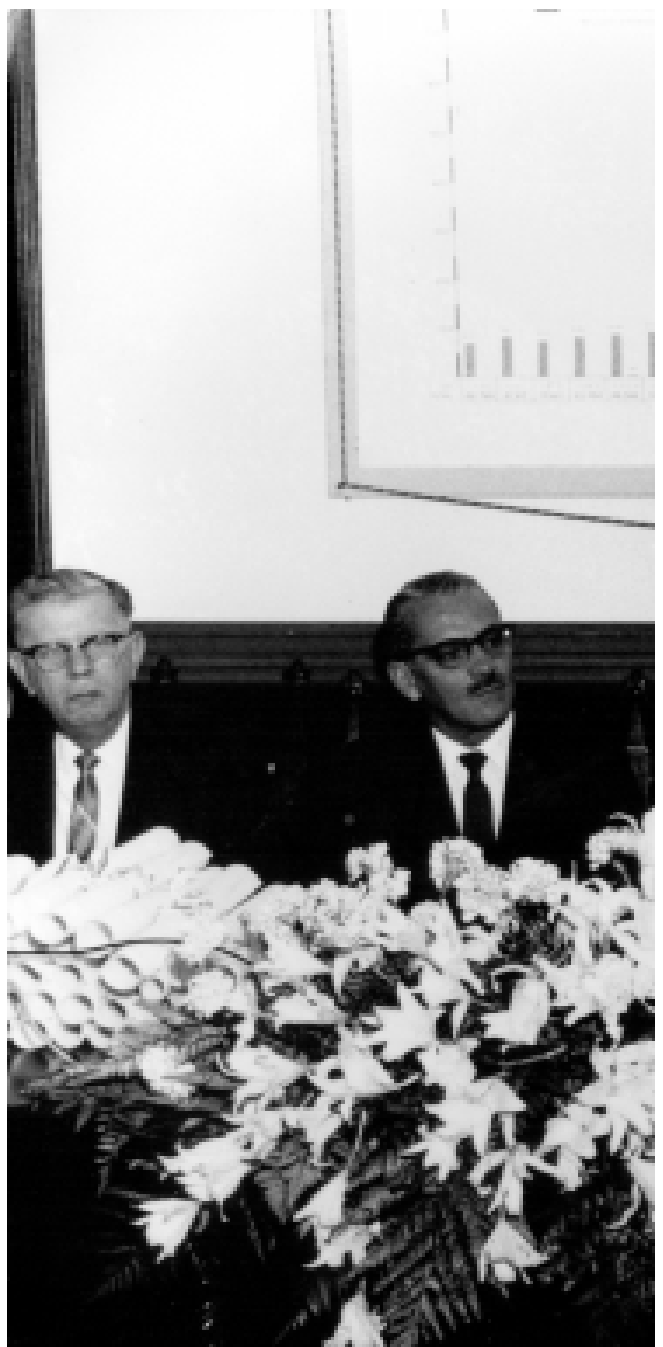




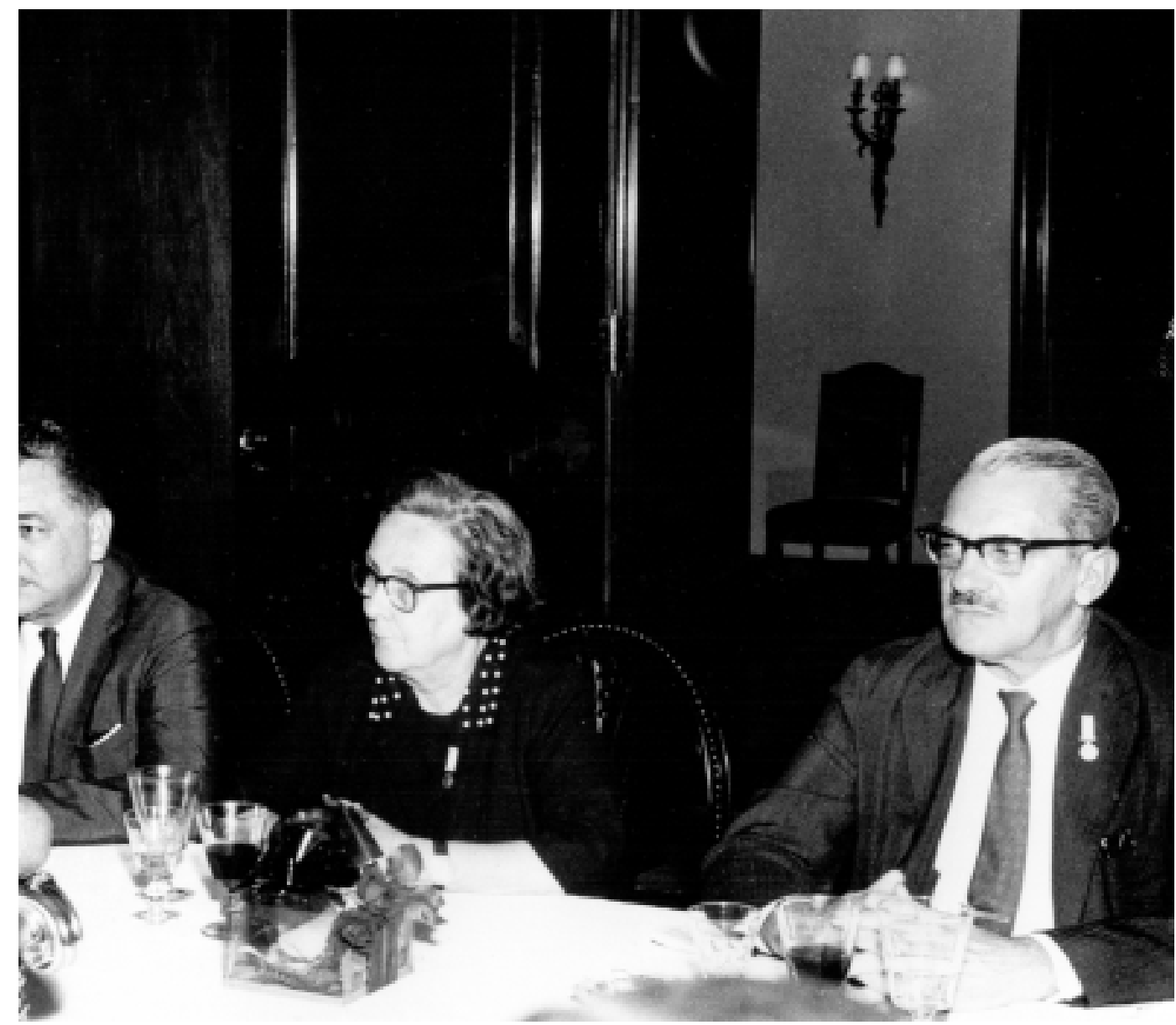

Comemoração do jubileu de prata do Instituto Adolfo Lutz em outubro de 1965. Da direita para a esquerda: dr. Jairo Cavalheiro Dias, Bertha Lutz, professores Aristides V. Freire e Alberto Chap Chap.

Foto cedida por

Charlotte Emmerich.

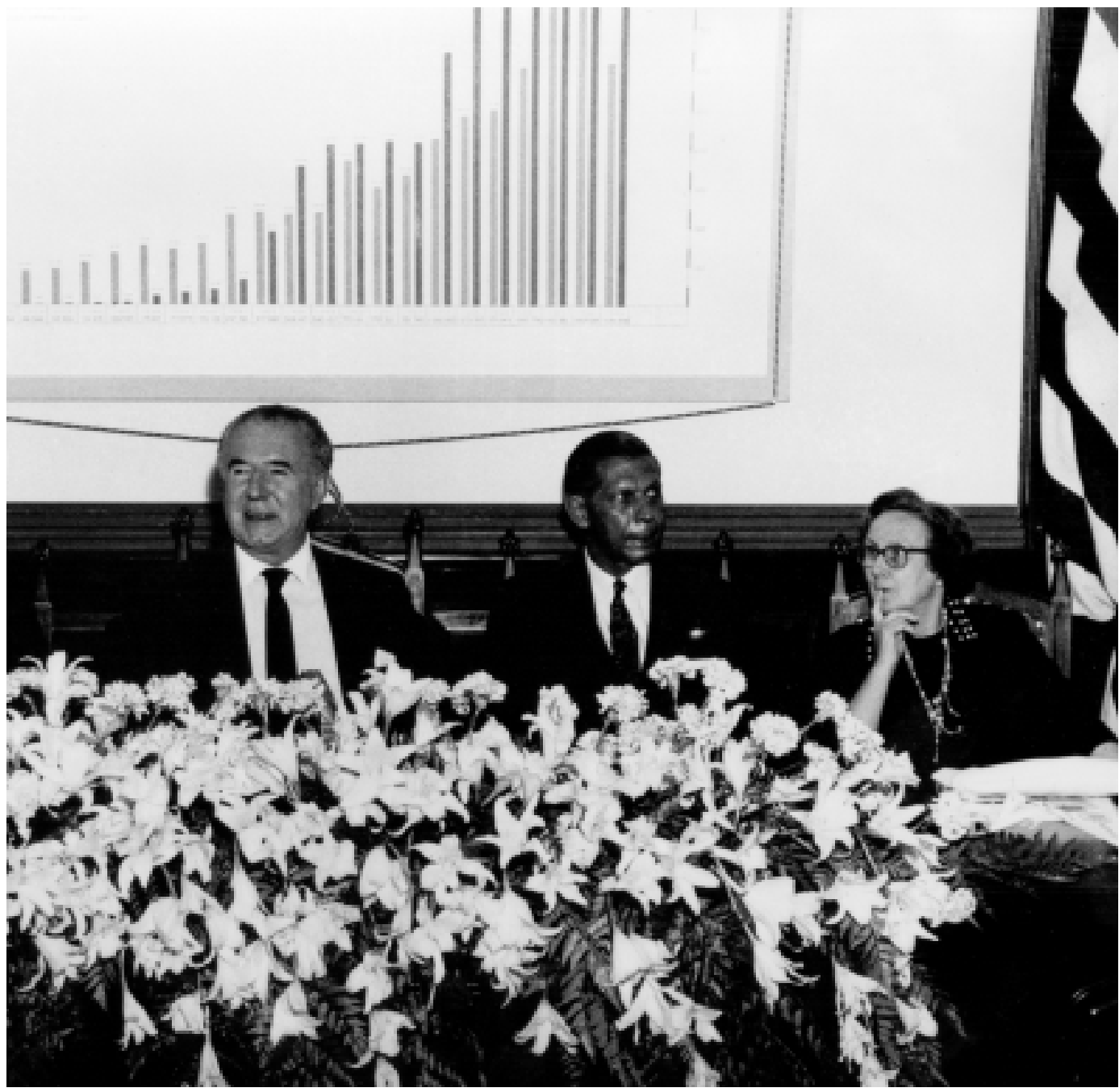

Jubileu de prata do Instituto Adolpho Lutz. Da direita para a esquerda: Bertha Lutz; Ariosto Büller Souto, diretor do Instituto Adolpho Lutz; Adhemar de Barros, governador de São Paulo; Jairo Cavalheiro Dias, secretário estadual de Saúde; e Paulo Antunes, professor da Faculdade de Higiene e Saúde. Foto cedida por Charlotte Emmerich. 


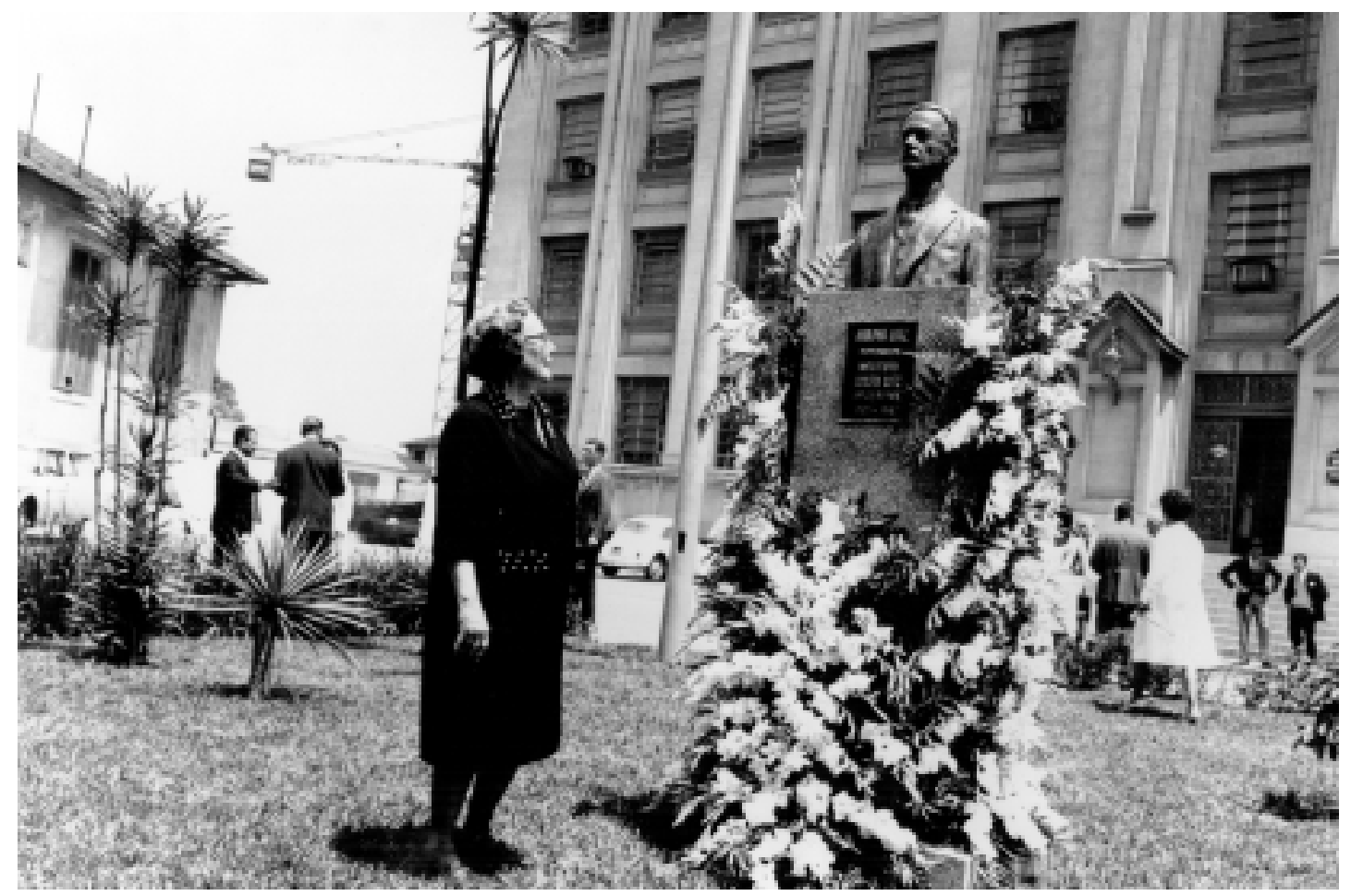

Bertha contempla o busto do pai. Foto cedida por Charlotte Emmerich.

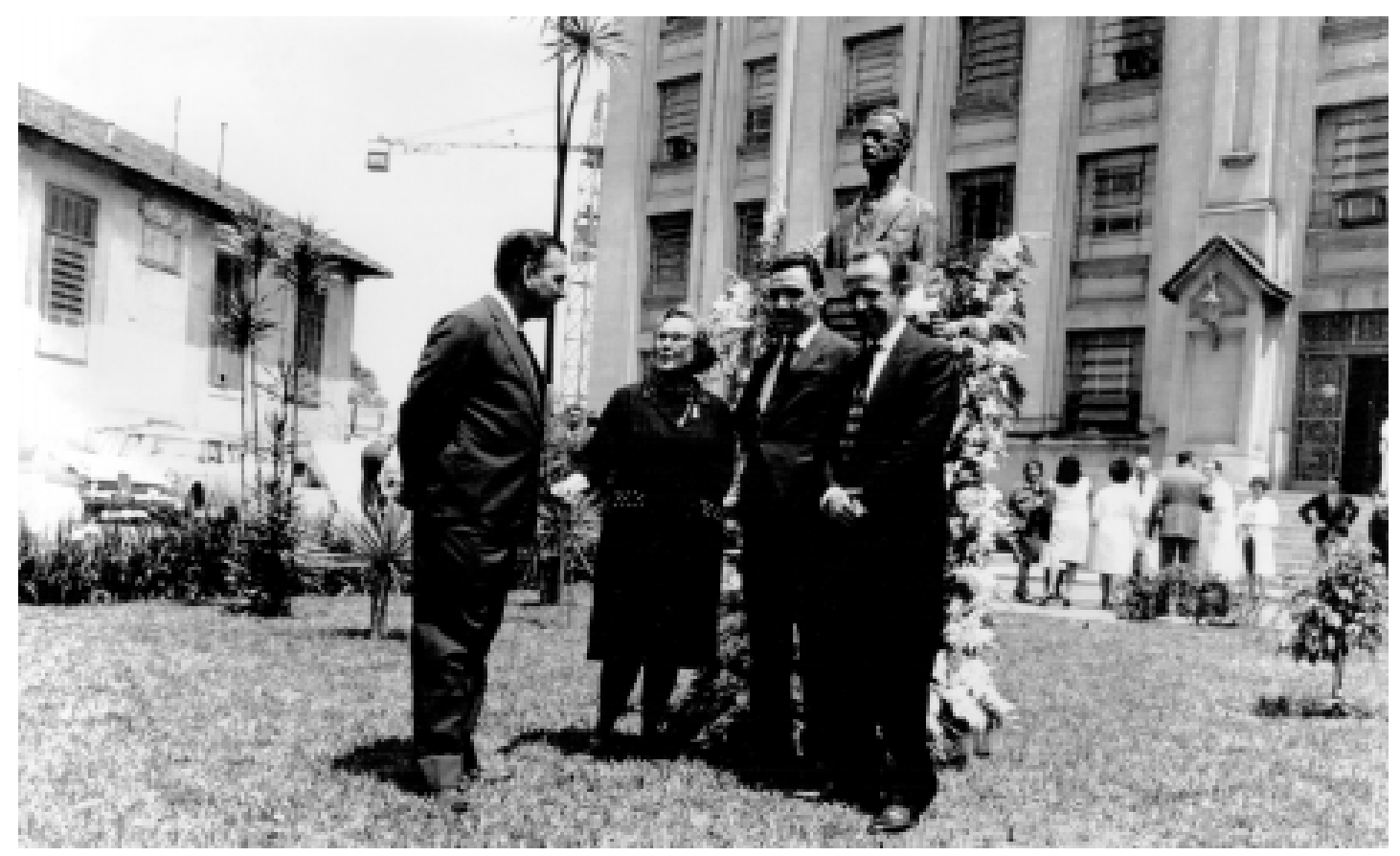

Inauguração do busto de Adolpho Lutz. Da esquerda para a direita, Adhemar de Barros, Bertha Lutz e Jairo Cavalheiro Dias e uma pessoa não identificada. Foto cedida por Charlotte Emmerich. 